Historic, archived document

Do not assume content reflects current scientific knowledge, policies, or practices. 



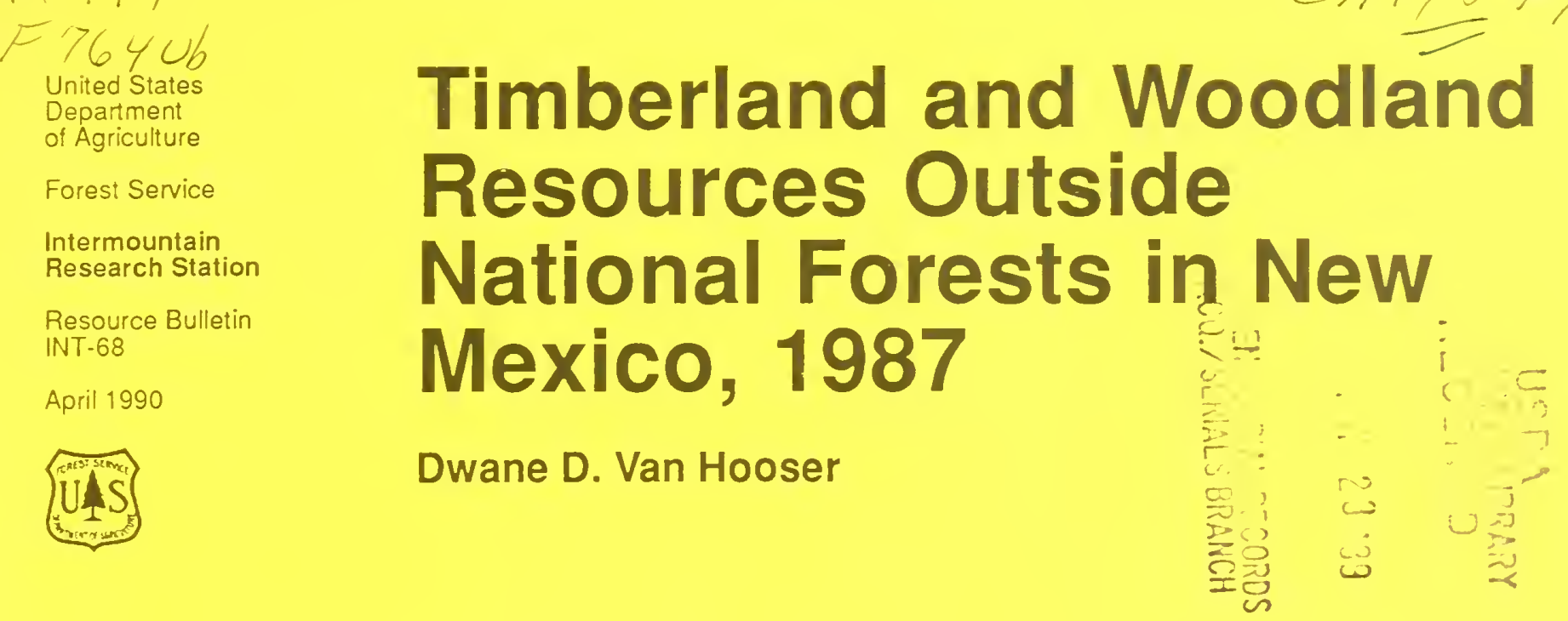

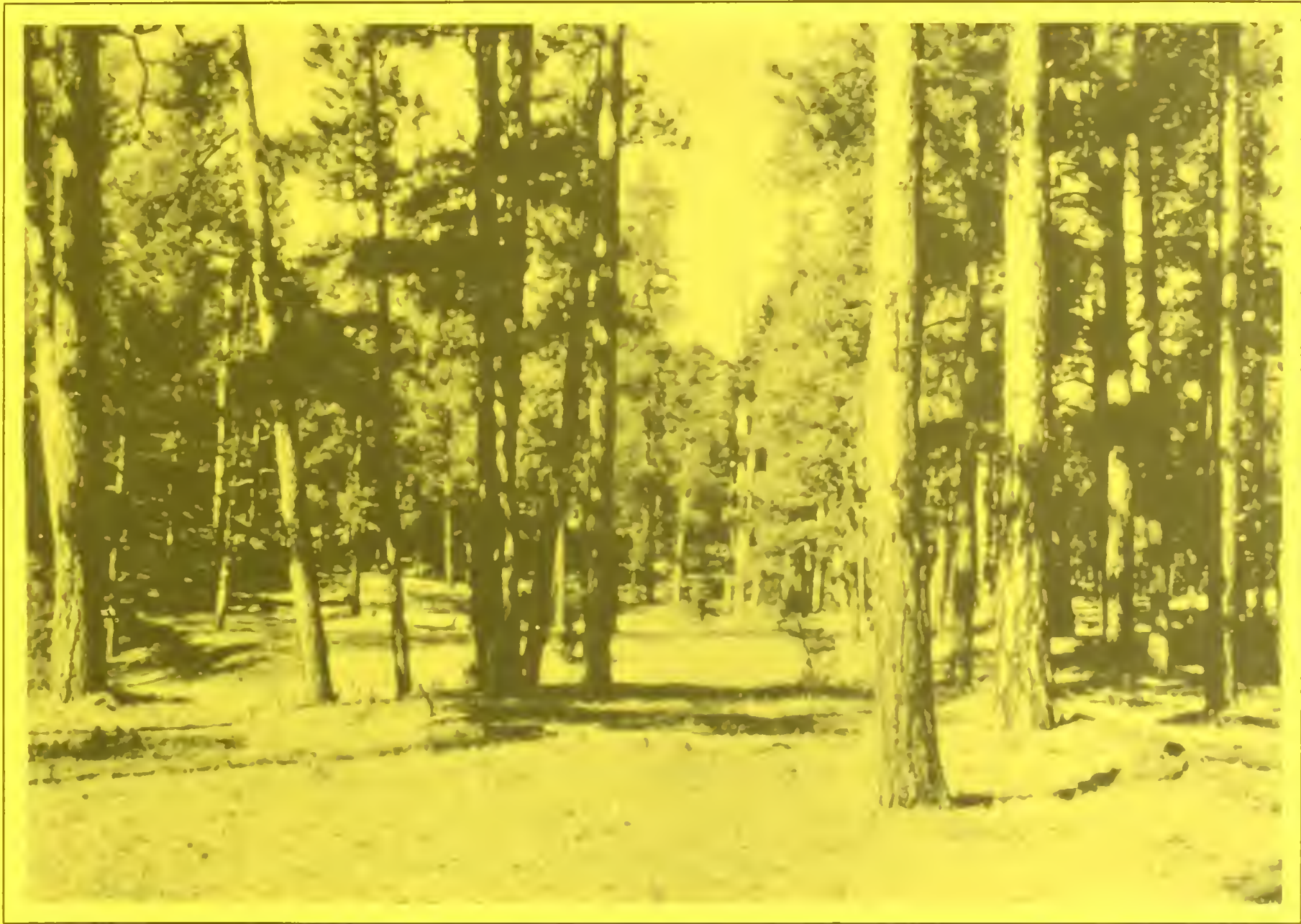




\section{THE AUTHOR}

DWANE D. VAN HOOSER is project leader of the Forest Survey Research Work Unit at the Intermountain Research Station. He holds a B.S. degree in forestry and an M.S. degree in forestry and business management from Southern Illinois University, Carbondale. He began his Forest Service career in 1964 with the Southern Forest Experiment Station, New Orleans. Before coming to Ogden, he held a staff position at the Forest Service national headquarters in Washington, DC.

\section{ACKNOWLEDGMENTS}

The Intermountain Research Station gratefully acknowledges the cooperation of the State Office of the Bureau of Land Management and personnel from the Bureau of Indian Affairs, both in the U.S. Department of the Interior. We extend a special note of gratitude to Bill Chapel, New Mexico State Forester, and his staff; and to the private land owners who provided information and access to field sample locations.

\section{RESEARCH SUMMARY}

The forest land base outside the National Forests in New Mexico totals more than 8 million acres. Three-quarters of these forests are owned by private individuals or companies. Acres supporting stands of timber species total 2.1 million, while the woodland resource, typified by stands of pinyonjuniper, accounts for more than 5.7 million acres. These areas contain wood volumes of 2.1 billion cubic feet and 2.7 billion cubic feet, respectively. This report presents additional information on the land base, timberland and woodland area, and associated inventory volume, growth, and mortality.

\section{PREFACE}

The primary objective of Forest Survey-a continuing nationwide undertaking of the Forest Service, U.S. Department of Agriculture - is to provide an assessment of the renewable resources for the forest lands of the Nation. Fundamental to the accomplishment of the objective are the periodic State-by-State resource inventories. Originally, Forest Survey was authorized by the McSweeney-McNary Act of 1928. The current authorization is through the Renewable Resources Research Act of 1978.
The Intermountain Research Station with headquarters in Ogden, UT, conducts the forest resource inventories for the Rocky Mountain States of Arizona, Colorado, Idaho, Montana, New Mexico, Nevada, Utah, and Wyoming. These inventories provide information on the extent and condition of the forests - its volume of wood and stand dynamics as expressed by growth, removals, and mortality for State, privately owned, and most other forest lands not in the National Forest System. These data, when combined with similar information on National Forest lands, provide a basis for forming forest policies and programs and for the orderly development and use of the resources.

\section{CONTENTS}

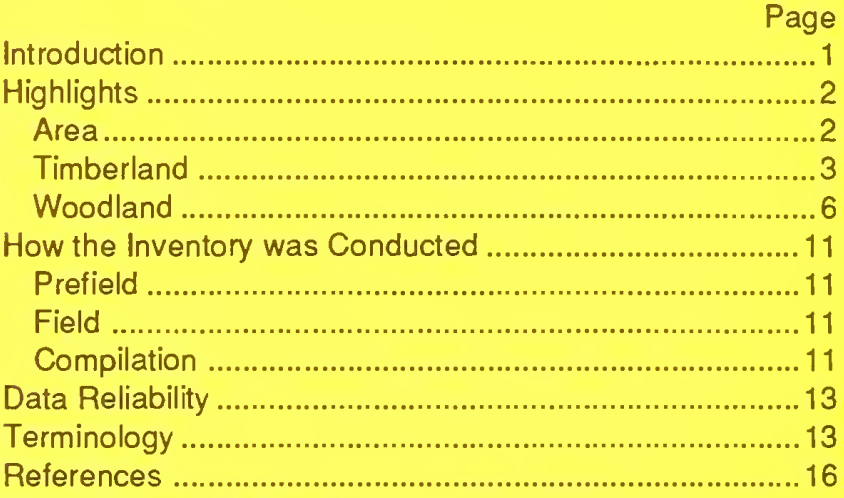

Forest Survey Tables

1 Total land and water area by ownership class in New Mexico, 1987

2 Area of forest land outside National Forests with percent standard error in New Mexico, 1987. 18

3 Net volume, net annual growth, and annual mortality of growing stock and sawtimber on forest land outside National Forests with percent standard error in New Mexico.

4 Total land area outside National Forests by major land class and ownership class in New Mexico, 1987

\section{Timberland Tables}

5 Area of timberland outside National Forests by forest type, stand-size class, and productivity class in New Mexico, 1987

6 Area of other publicly owned timberland by forest type, stand-size class, and productivity class in New Mexico, 1987.

7 Area of privately owned timberland by forest type, stand-size class, and productivity class in New Mexico, 1987 


\title{
Timberland and Woodland Resources Outside National Forests in New Mexico, 1987
}

\author{
Dwane D. Van Hooser
}

\section{INTRODUCTION}

This report presents the principal findings of the most recent forest survey of the timberland and woodland resources outside the National Forests in New Mexico (fig. 1). Phase I of the survey began in 1985 with the collection and reconciliation of area information and aerial photo interpretation. The field phase began in early June 1986 and was completed in midNovember 1987.

The resource statistics in this report include estimates for those lands in private ownership and those public lands administered by the Bureau of Land Management (BLM), U.S. Department of the Interior (USDI); other Federal agencies; the State of New Mexico; and county and municipal governments. Reserved areas, such as those lands administered by the National Park Service, USDI, are not field sampled but are included in the total area summaries (table 1). Area estimates for those lands administered by the Forest Service, U.S. Department of Agriculture, are also included in table 1, but resource estimates are not included in this report. They will be combined with the estimates presented here and in previous substate reports to form the basis for a comprehensive statewide analysis of New Mexico's forest resources.

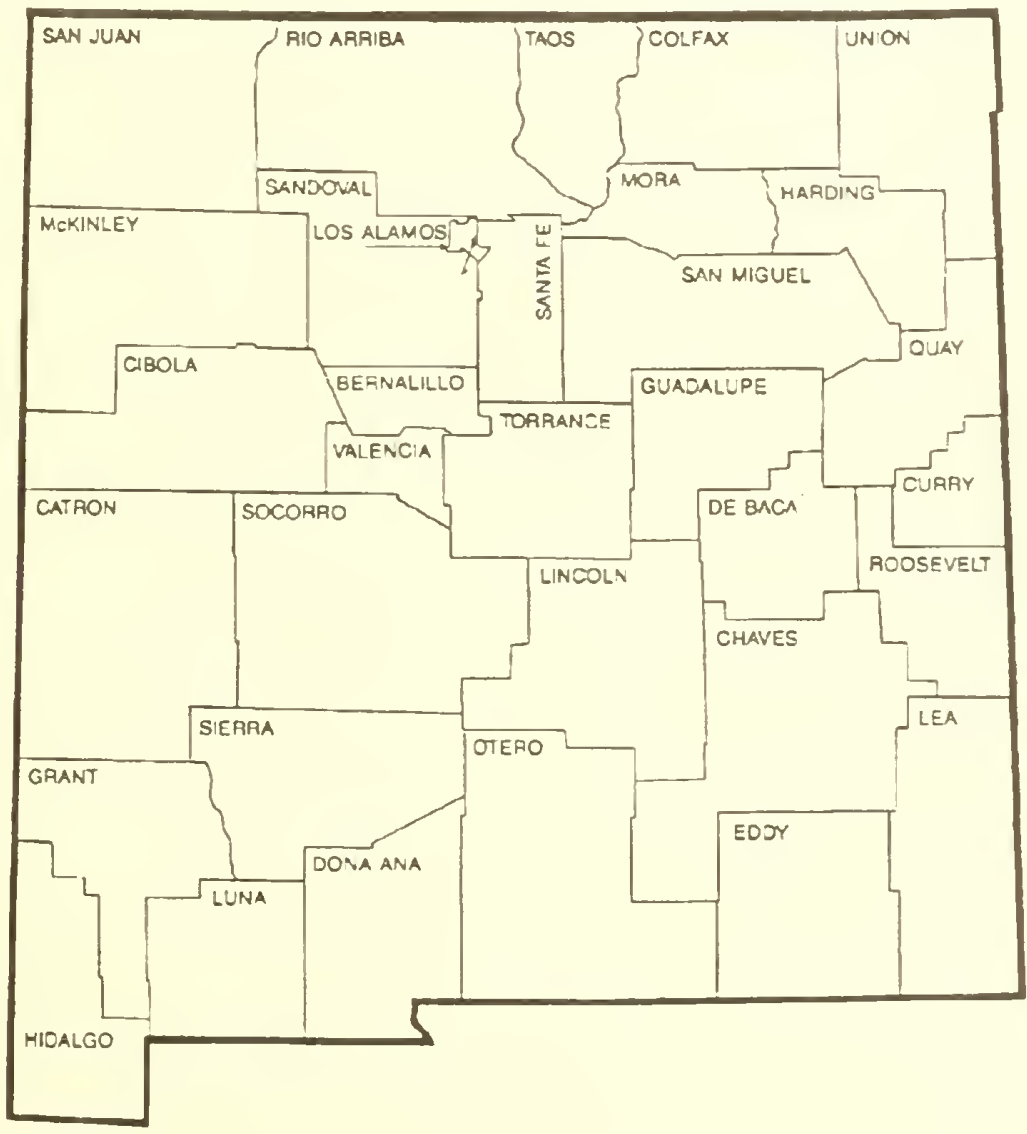

Figure 1-New Mexico counties. 


\section{HIGHLIGHTS}

The total land area of the State of New Mexico is 77.8 million acres. Some 36.6 million acres are administered by public agencies (fig. 2).

Those lands outside the National Forests, the subject of this report, amount to 68.4 million acres. Of these, BLM and other Federal agencies administer 16.5 million acres, while New Mexico State agencies and county and municipal governments control over 9.7 million acres.

Of the 68.4 million acres outside the National Forests, 8.1 million meet the minimum tree stocking criteria to be considered forest (fig. 3). A small amount of this area-some 3 percent-is reserved by statute or administrative regulation. Just over one-fourth of the nonreserved forest land is timberland, and 73 percent is classified as woodland.

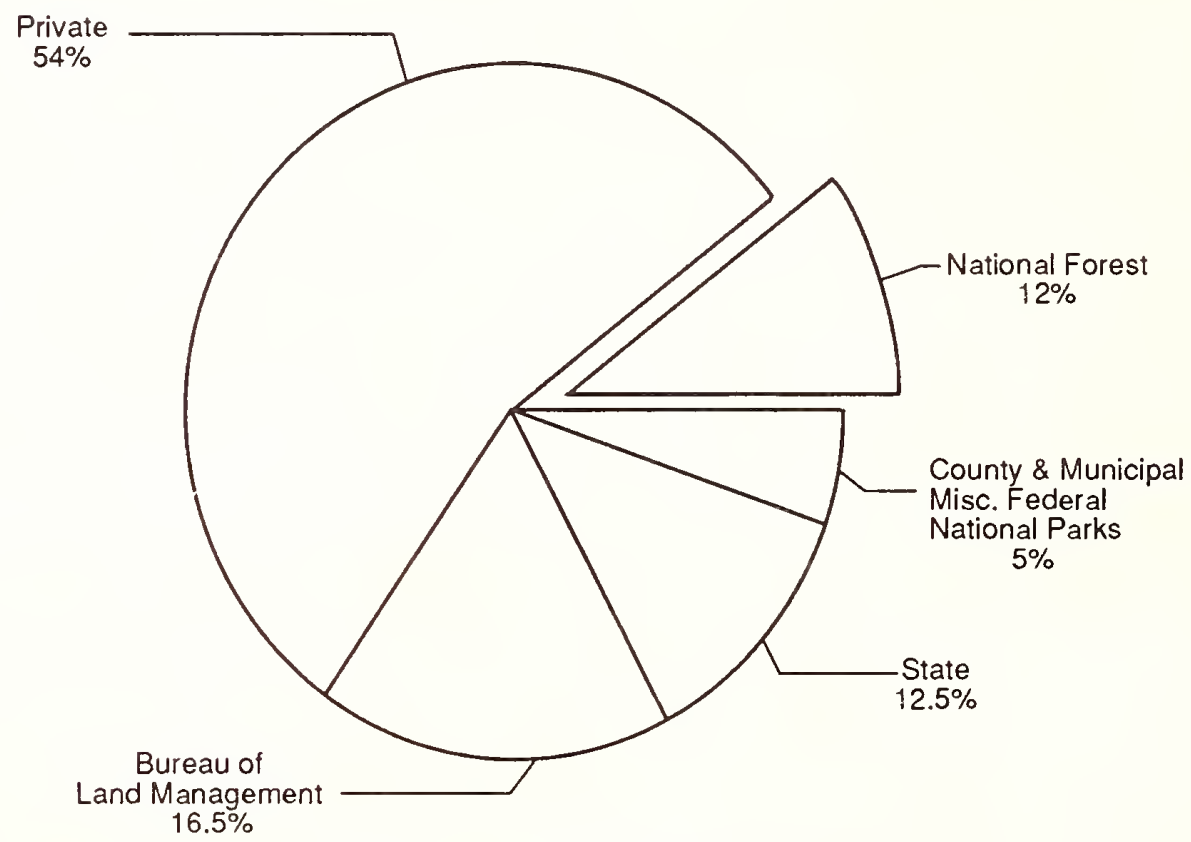

Figure 2-Distribution of land by ownership in New Mexico, 1987.

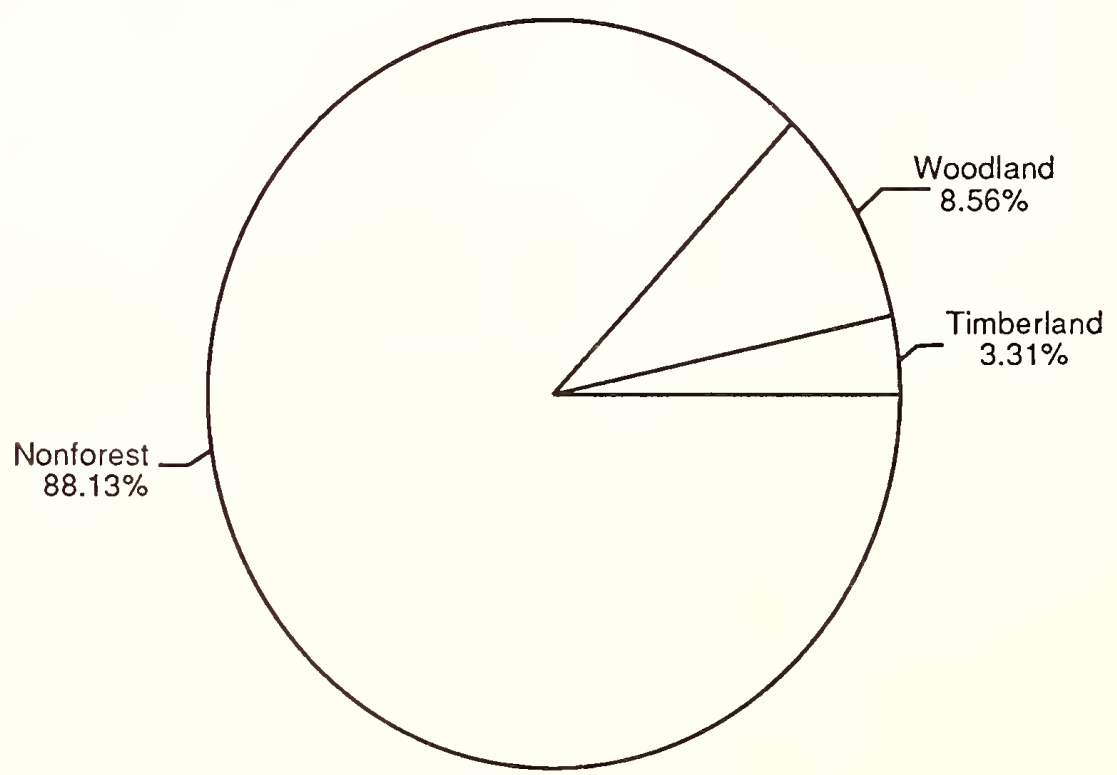

Figure 3-Distribution of land outside National Forests by type of land in New Mexico, 1987. 


\section{Timberland}

Area-Of the 2.1 million acres of timberland, most-94 percent-is in private holdings. The timberland areas are concentrated in the Sangre de Cristo Mountains in the north central portion of the State and in the Sacramento Mountains to the south. More than half of the timberland is concentrated in four counties-Colfax, Rio Arriba, Mora, and Taos.

The ponderosa pine forest type is predominant on nearly 60 percent of the timberland area (fig. 4). The Douglas-fir type accounts for 18 percent. The white fir, spruce-fir, and spruce forest types combined occupy another 17 percent. Other softwoods, aspen, and cottonwood types are found on the remainder of the timberland areas, with the cottonwood occurring primarily along the Rio Grande River in the central part of the State.

More than three-quarters of the timberland area is in sawtimber stands (fig. 5). Poletimber stands predominate on 18 percent of the area. Nonstocked conditions occur on only 4 percent of the timberland acres.

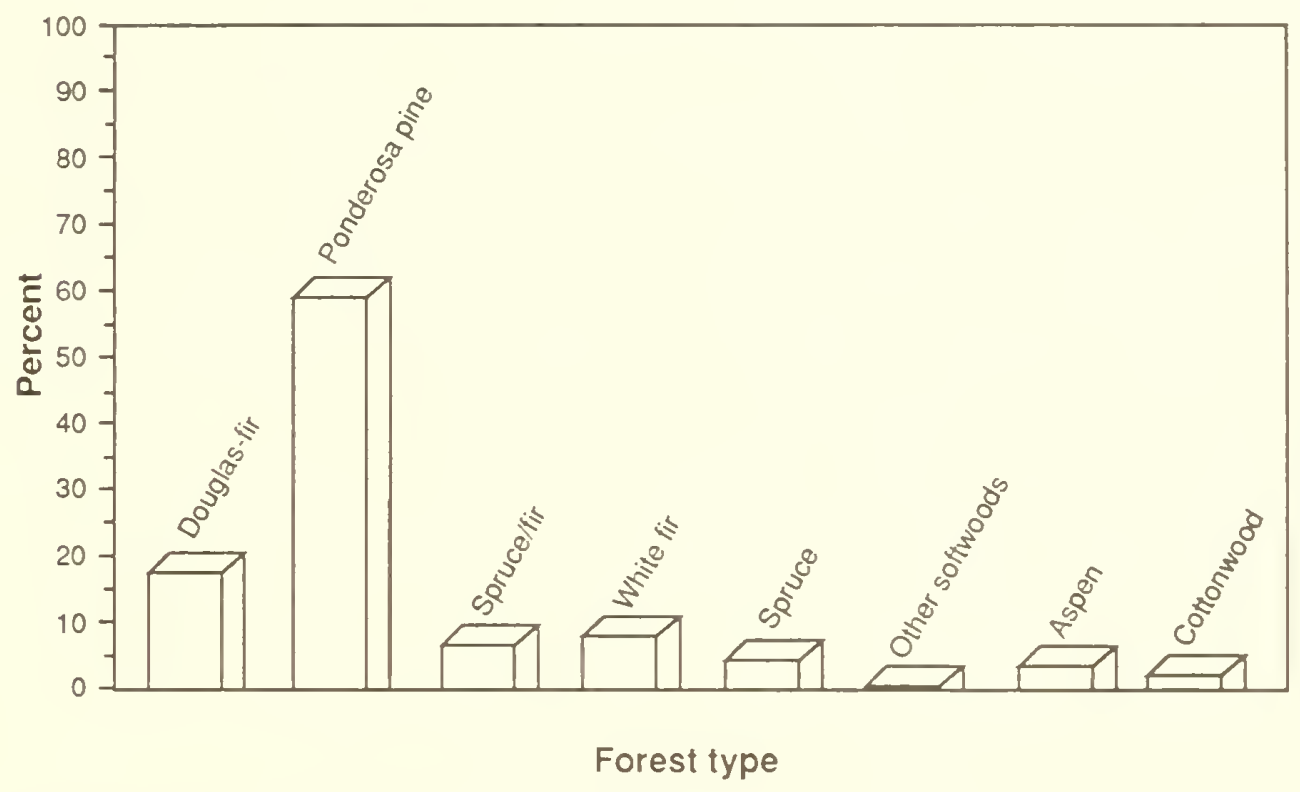

Figure 4-Distribution of timberland outside National Forests by forest type in New Mexico, 1987.

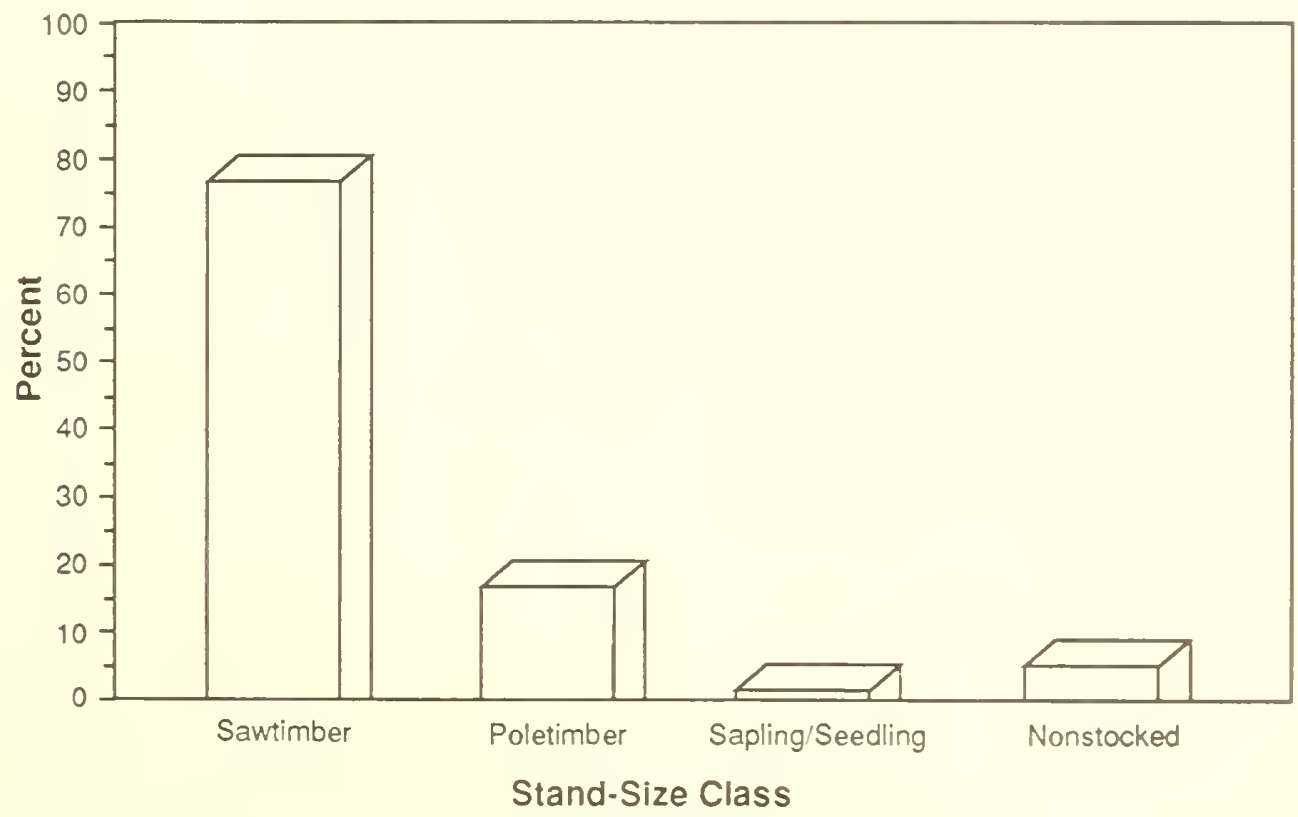

Figure 5-Distribution of timberland outside National Forests by stand-size class in New Mexico, 1987. 
All of the timberland has the potential to produce at least 20 cubic feet of volume per acre per year at culmination of mean annual increment (MAI). More than one-fourth of the land has the inherent ability to grow more than 50 cubic feet MAI.

Nearly half of the timberland area supports between 1,500 and 5,000 board feet of sawtimber per acre (fig. 6). A small amount-6 percent of the timberland base-supports stands containing 10,000 or more board feet of volume per acre.

Nearly three-fifths of the timberland acres are at least medium to fully stocked, and 28 percent are considered fully stocked. About one-fifth of the timberland is in stands over 100 years of age. The remaining 22 percent is either nonstocked or poorly stocked (fig. 7).

The timbered acres support more than 684 million trees, 96 percent of which are considered growing stock. Of these, about 60 percent are saplings, and 2 percent exceed 17.0 inches diameter at breast height (d.b.h.) (fig. 8). Most of the non-growing-stock trees are those that are dead but still meet merchantability standards for growing stock. Less than 1 percent of the standing inventory is in rough or rotten cull trees.

Volume-The volume in growing-stock trees is estimated to be more than 2 billion cubic feet and includes nearly 8 billion board feet of sawtimber. Trees classified as rough or rotten cull, or salvable dead, contribute an additional 151 million cubic feet of volume.

More than 80 percent of the growing-stock volume is contained in sawtimber-size stands. Less than 1 percent is in nonstocked and seedling/sapling stands. Nearly 95 percent of both the growing-stock and sawtimber inventories are in private ownership.

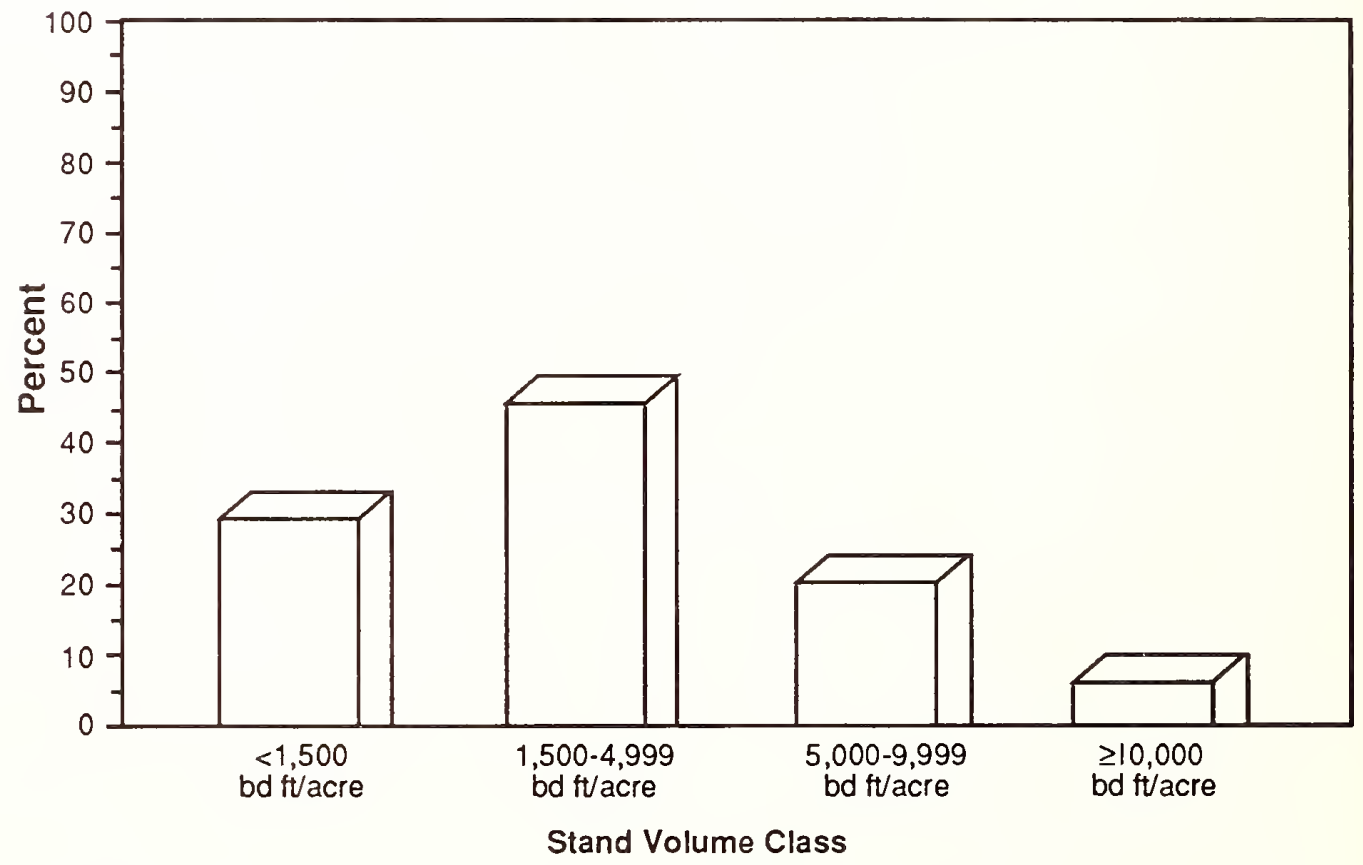

Figure 6-Distribution of timberland outside National Forests by stand-volume class in New Mexico, 1987. 


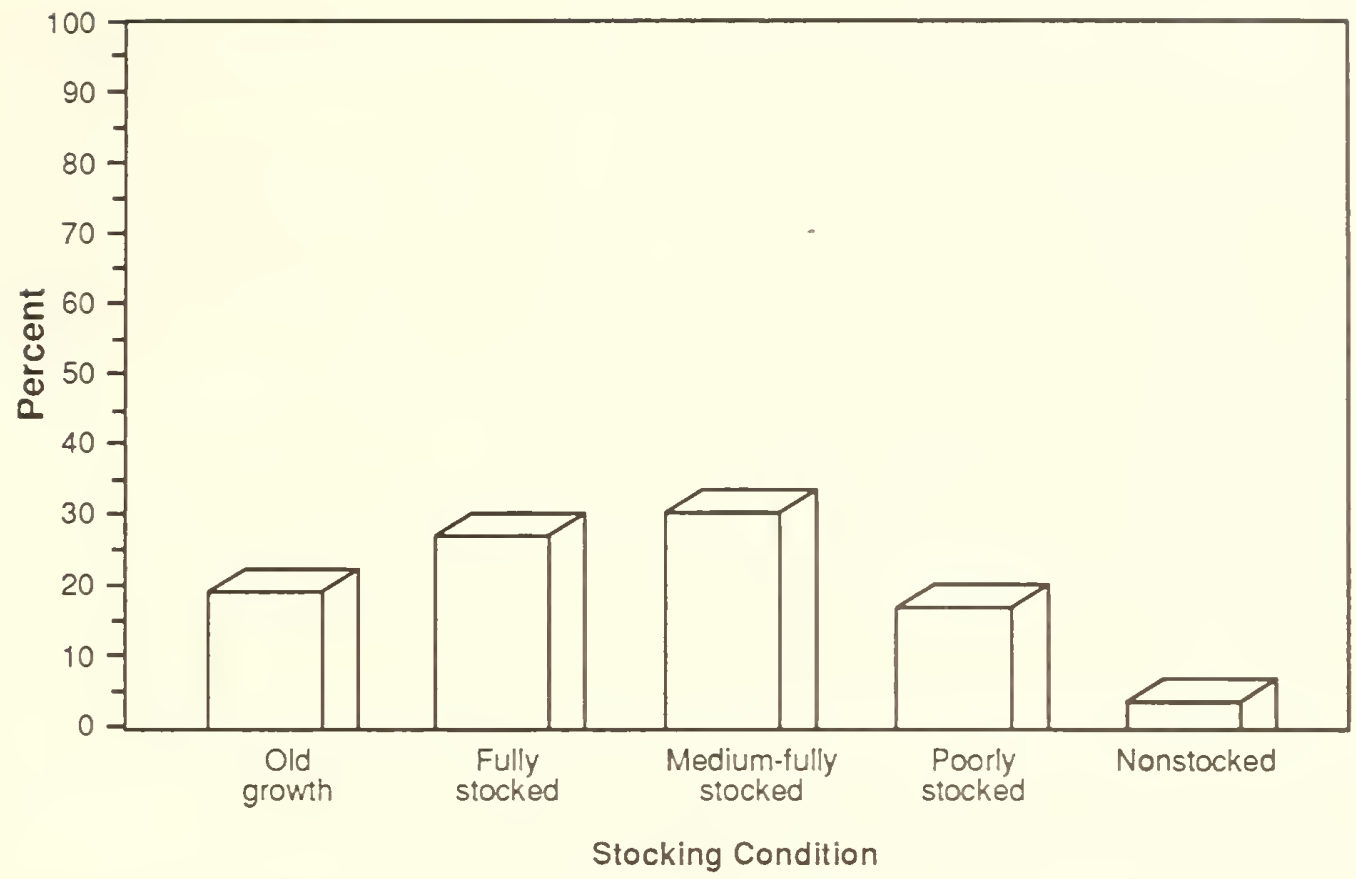

Figure 7-Distribution of timberland outside National Forests by stocking condition in New Mexico, 1987.

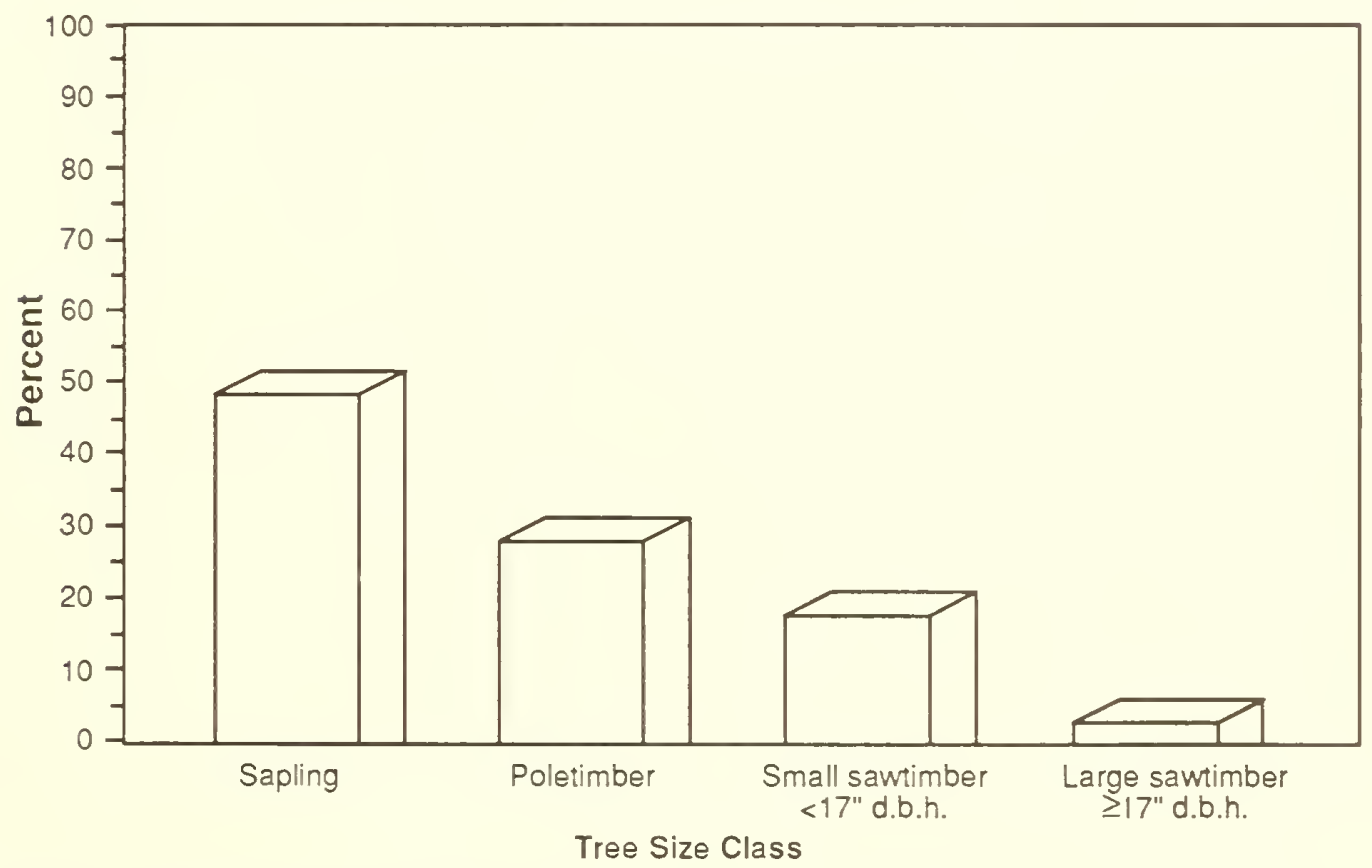

Figure 8-Distribution of growing-stock trees on timberland outside National Forests by tree-size class in New Mexico, 1987. 
One-half of the growing stock inventory is in small sawtimber-size trees, and more than one-fifth is in poletimber-size trees (fig. 9). Three-fifths of the sawtimber inventory is in trees less than 17.0 inches d.b.h.

The most abundant species in terms of growing stock and sawtimber volume is ponderosa pine (Pinus ponderosa) (fig. 10). Altogether this species accounts for 45 percent of the cubic volume and fully half of the 7.9 billion board feet of sawtimber. Douglas-fir (Pseudotsuga menziesii) is the second most abundant species, contributing about one-fifth of the total cubic-foot and board-foot volume. White fir (Abies concolor) and Engelmann spruce (Picea engelmannii) each contribute about 10 percent to the standing inventory. Aspen (Populus tremuloides) is the dominant hardwood species, adding some 155 million cubic feet to the growing-stock inventory.

Components of Change-On an average annual basis, gross growth of growing stock is increasing the standing inventory by 61 million cubic feet or 3 percent. When mortality is deducted, however, the annual rate of change in the absence of harvest is 55 million cubic feet or 2.6 percent.

Mortality of growing stock is low, amounting to 6.2 million cubic feet and representing only three-tenths of 1 percent of the inventory. Nearly two-thirds of the mortality was due to insect-killed Douglas-fir. A minor amount of disease activity was also noted. For just over a fourth of the dead trees, a cause of death could not be determined.

\section{Woodland}

Area-Some 5.7 million acres or 73 percent of the forested area is classified as woodland. The BLM administers nearly a million acres. Other public agencies exercise control over an additional 750,000 acres. The bulk of the woodland-nearly 70 percent-is privately owned (fig. 11).

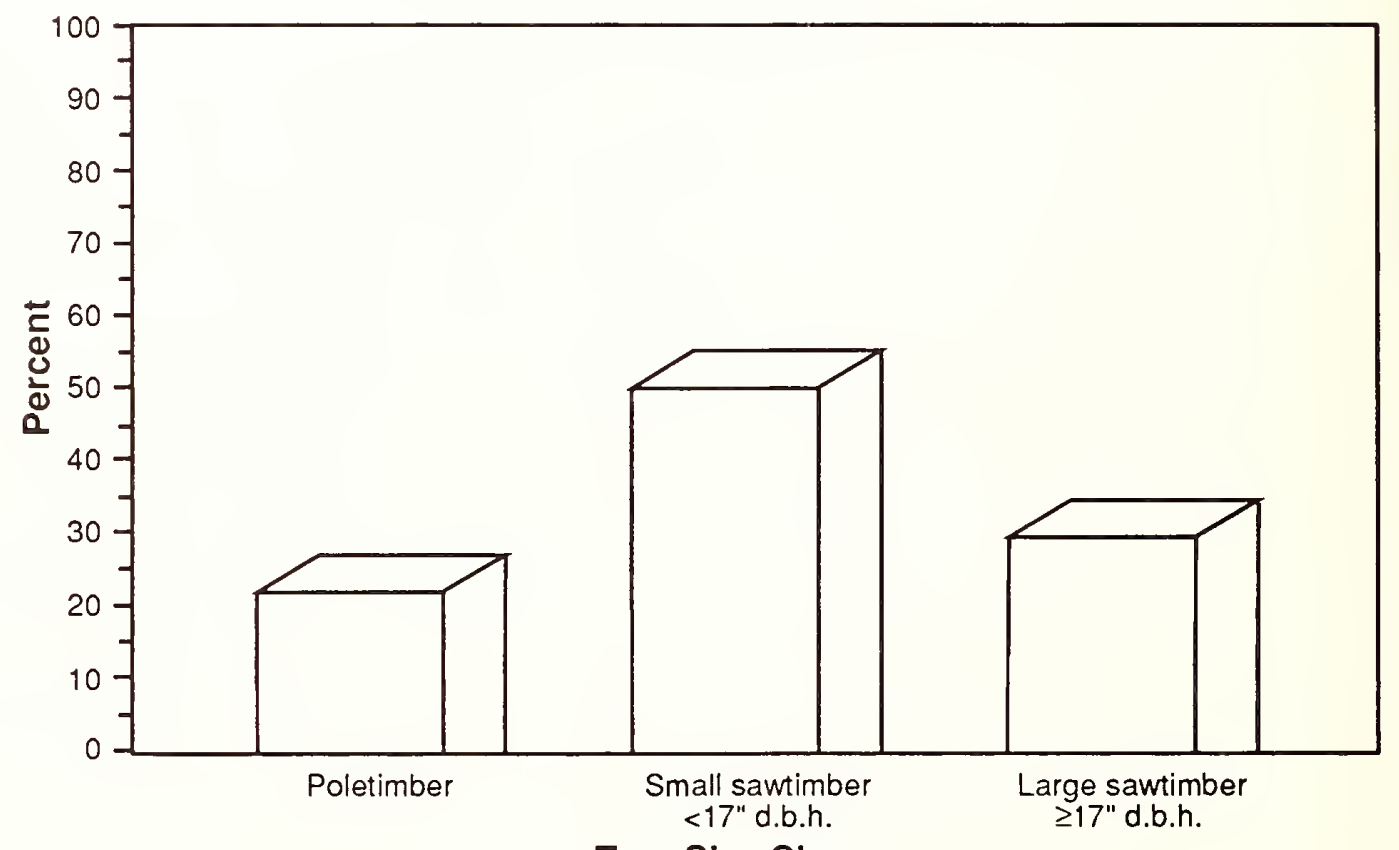

Figure 9-Distribution of growing-stock volume on timberland outside National Forests by tree-size class in New Mexico, 1987. 


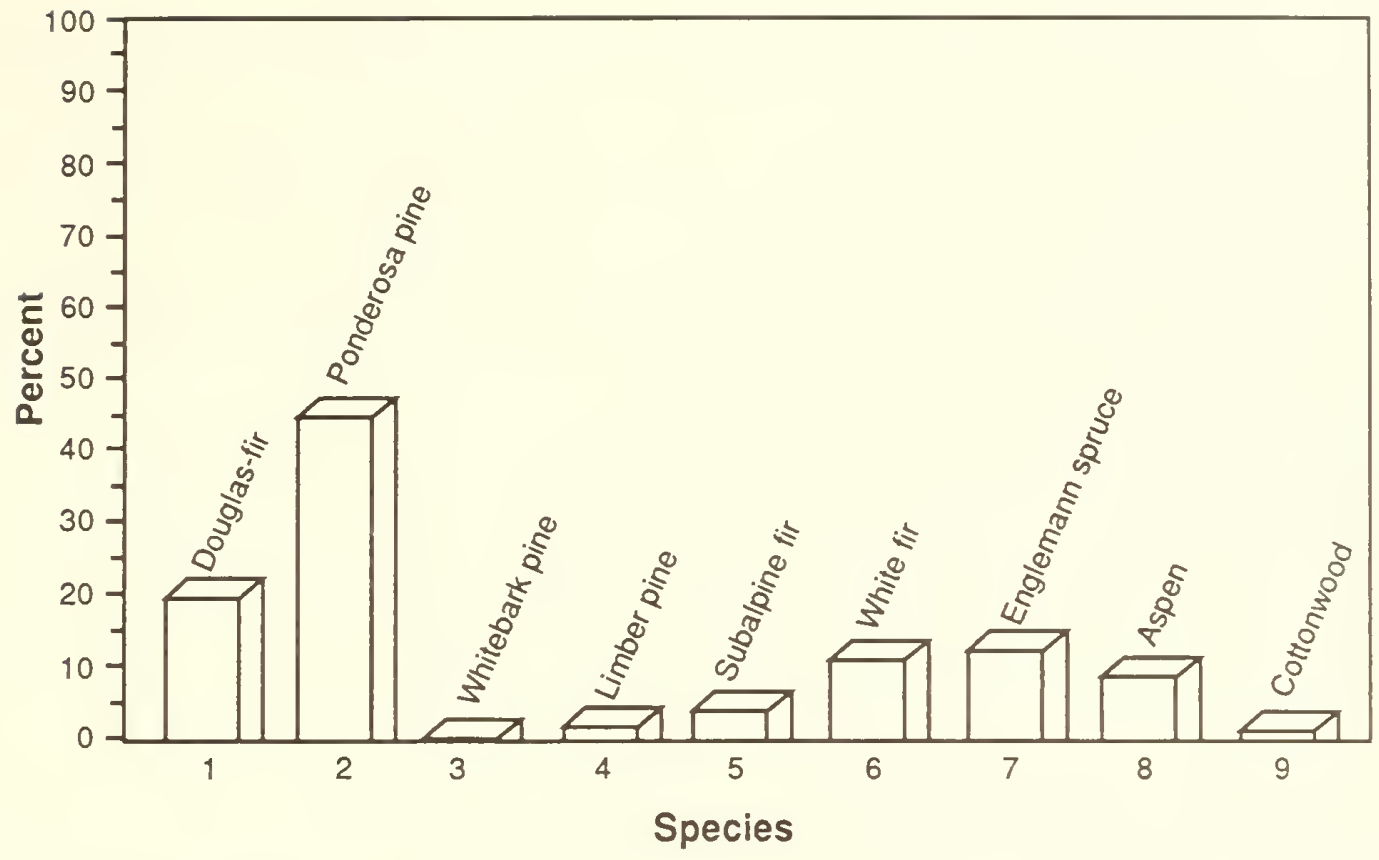

Figure 10-Distribution of growing-stock volume on timberland outside National Forests by species in New Mexico, 1987.

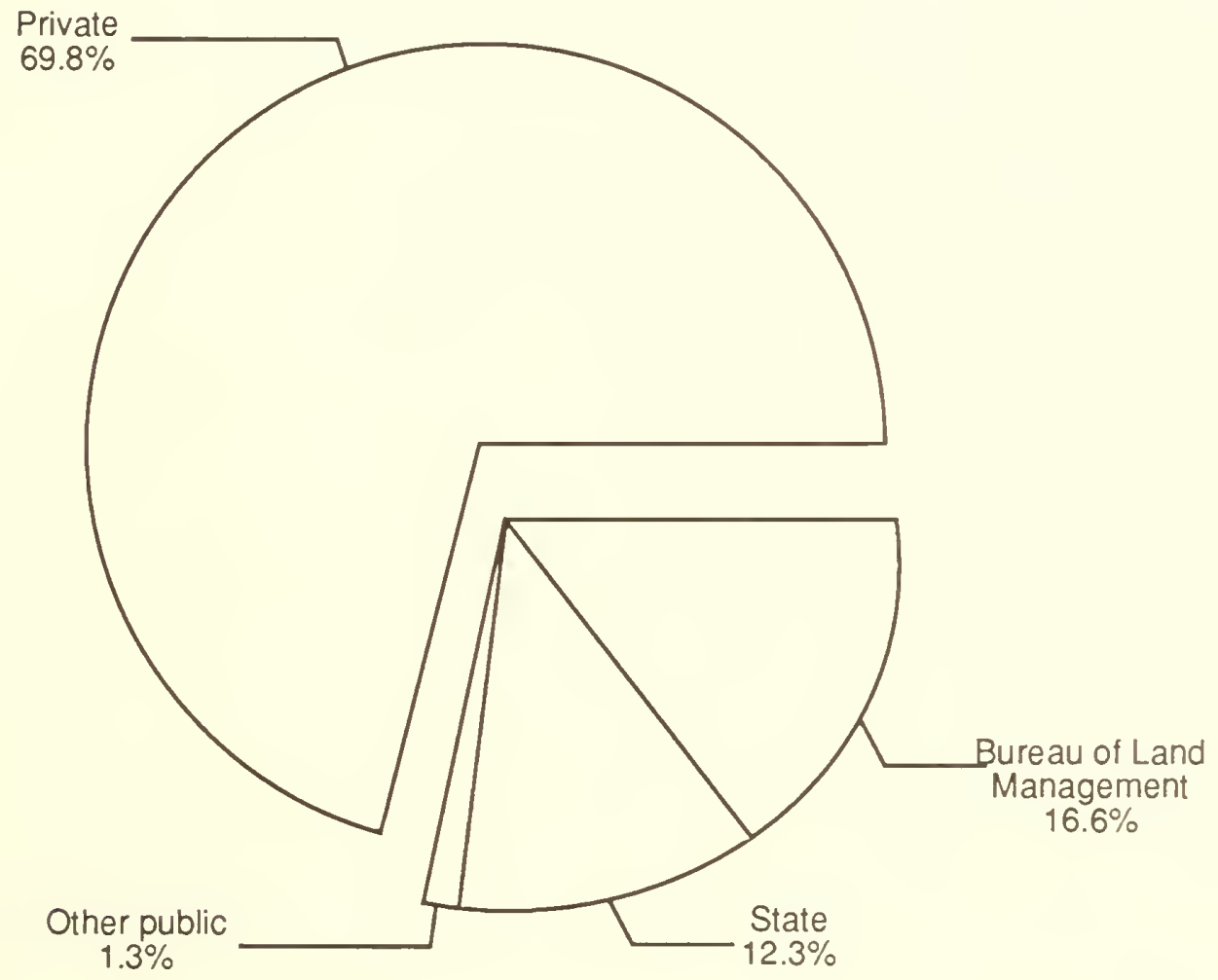

Figure 11-Distribution of woodland outside National Forests by ownership in New Mexico, 1987. 
The most dominant vegetative type on the woodland areas is the pinyon-juniper complex. Altogether this type occupies more than 5 million acres -88 percent of the woodland area (fig. 12). The next most abundant type is made up of more or less pure stands of juniper that contain no pinyon (Pinus edulis). Rocky Mountain (Juniperus scopulorum), Utah (J. osteosperma), oneseed ( $J$. monosperma), or alligator ( $J$. deppeana) juniper occupy 522,000 acres. A third type, which is found on 181,000 acres of woodland, is oak, the principal species being Gambel oak (Quercus gambelii).

Each woodland site is classified according to its ability to produce sustained crops of trees and its potential for management. About 80 percent of the pinyon-juniper sites demonstrated the physical and biological characteristics that might make them candidates for formal management and are thus classified as high site. Nearly 90 percent of the oak stands demonstrated similar characteristics. Overall, 80 percent of the woodland area was considered to be in this category (fig. 13). The 1.2 million acres placed in the low-site category were usually found on harsh, dry sites with shallow soils or steep slopes where vigorous growth and successful regeneration would be difficult, if not impossible, to achieve.

The woodland area supports more than 1.3 billion trees. The distribution of the inventory by size class bodes well for future stand development. Nearly one-third of the stems are less than 3.0 inches diameter at root collar (d.r.c.), and nearly 80 percent are less than 9.0 inches d.r.c. (fig. 14).

More than half of the trees are pinyon. The juniper species account for some 37 percent of the standing inventory, and the oaks account for 12 percent. A small segment is made up of other woodland species such as Prunus sp., walnut (Juglans major), maple (Acer glabrum, A. grandidentatum), box elder (Acer negundo), and ash (Fraxinus cuspidata, $F$. velutina). With the exception of the minor woodland species, the trees are well distributed by size class, with trees being present in all d.r.c. classes. The juniper, however, tends to predominate in the larger d.r.c. classes.

Volume-New Mexico's woodlands support 2.7 billion cubic feet of volume; 72 percent is privately owned. Nearly half of the total volume is in juniper species, and 44 percent is in pinyon. The oaks contribute 4 percent to the standing volume. The remainder is in the minor woodland species and in timber species such as ponderosa pine, Douglas-fir, white fir, and cottonwood (Populus trichocarpa) found growing on woodland sites.

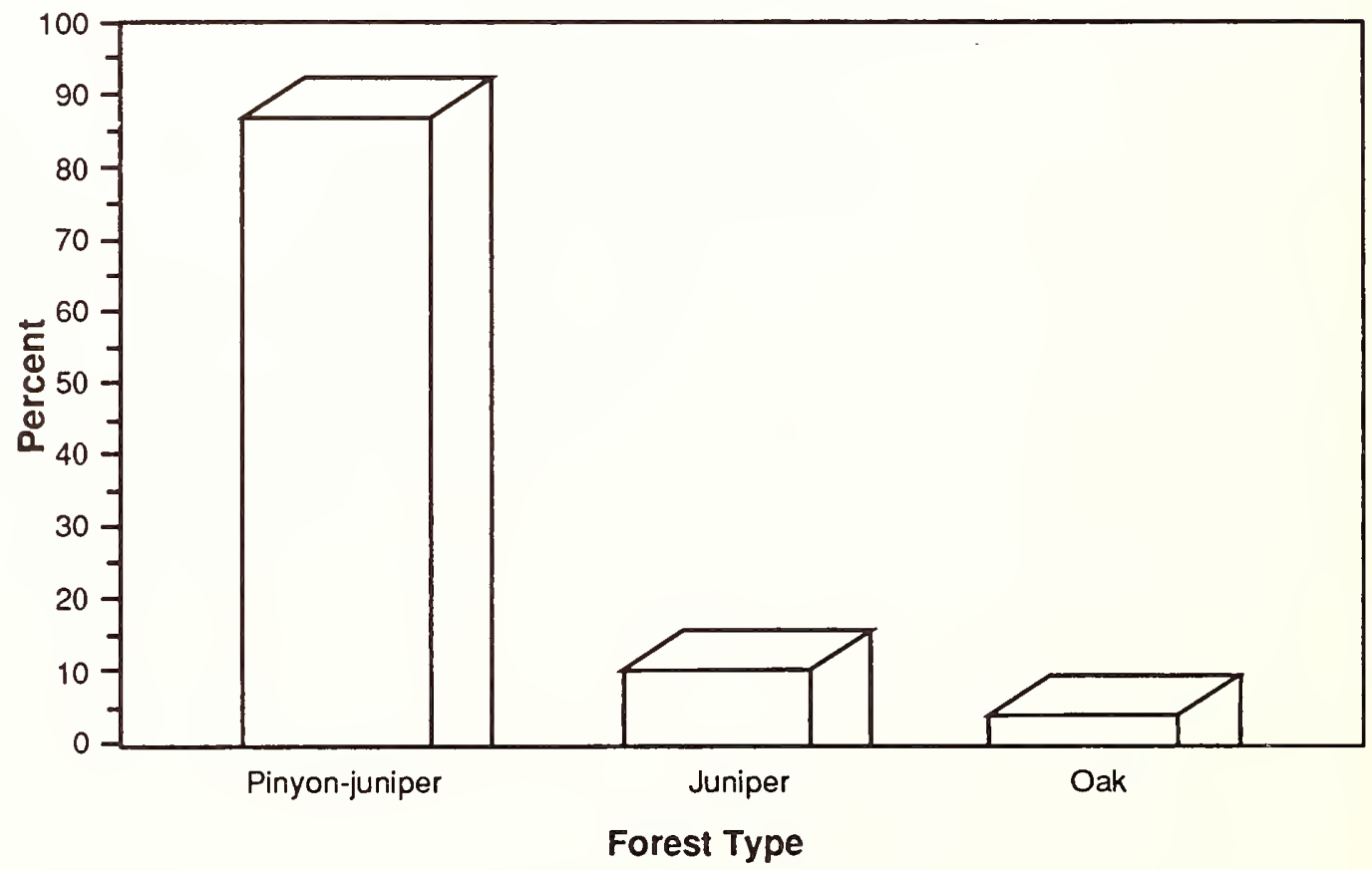

Figure 12-Distribution of woodland outside National Forests by forest type in New Mexico, 1987. 


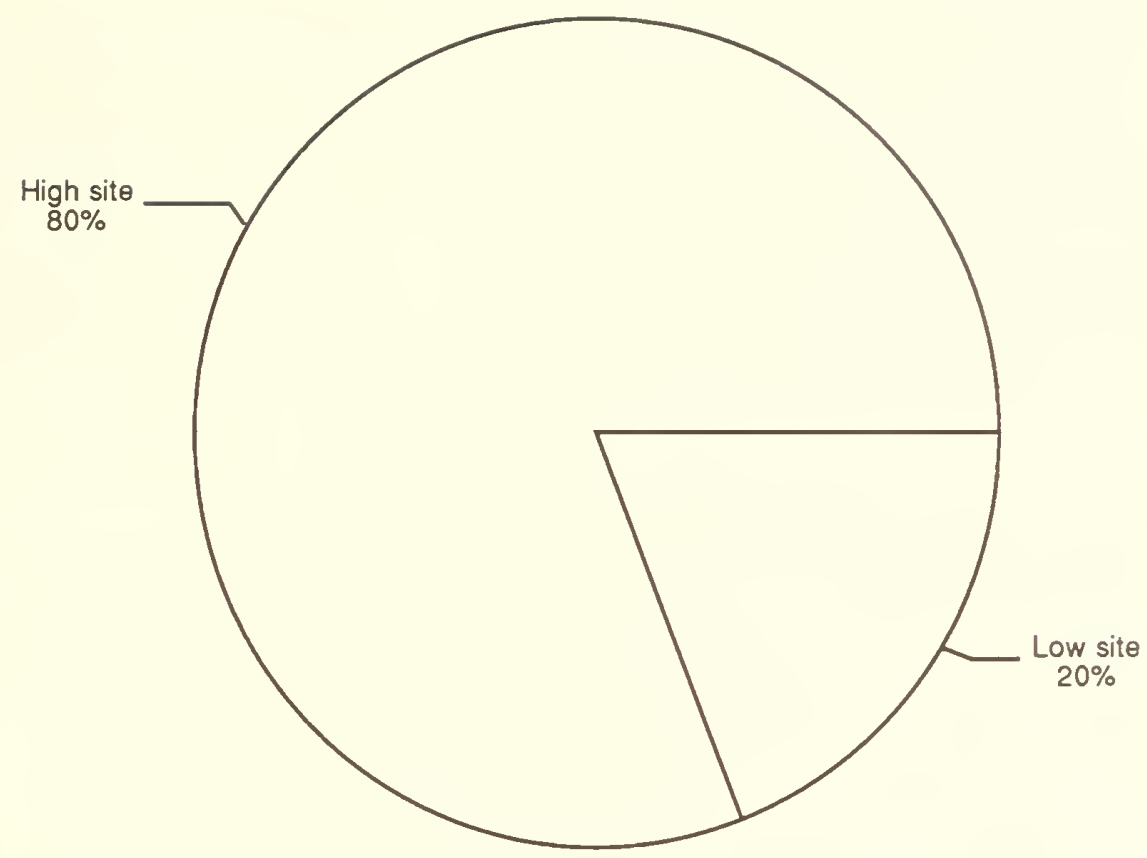

Figure 13-Distribution of woodland outside National Forests by productivity class in New Mexico, 1987.

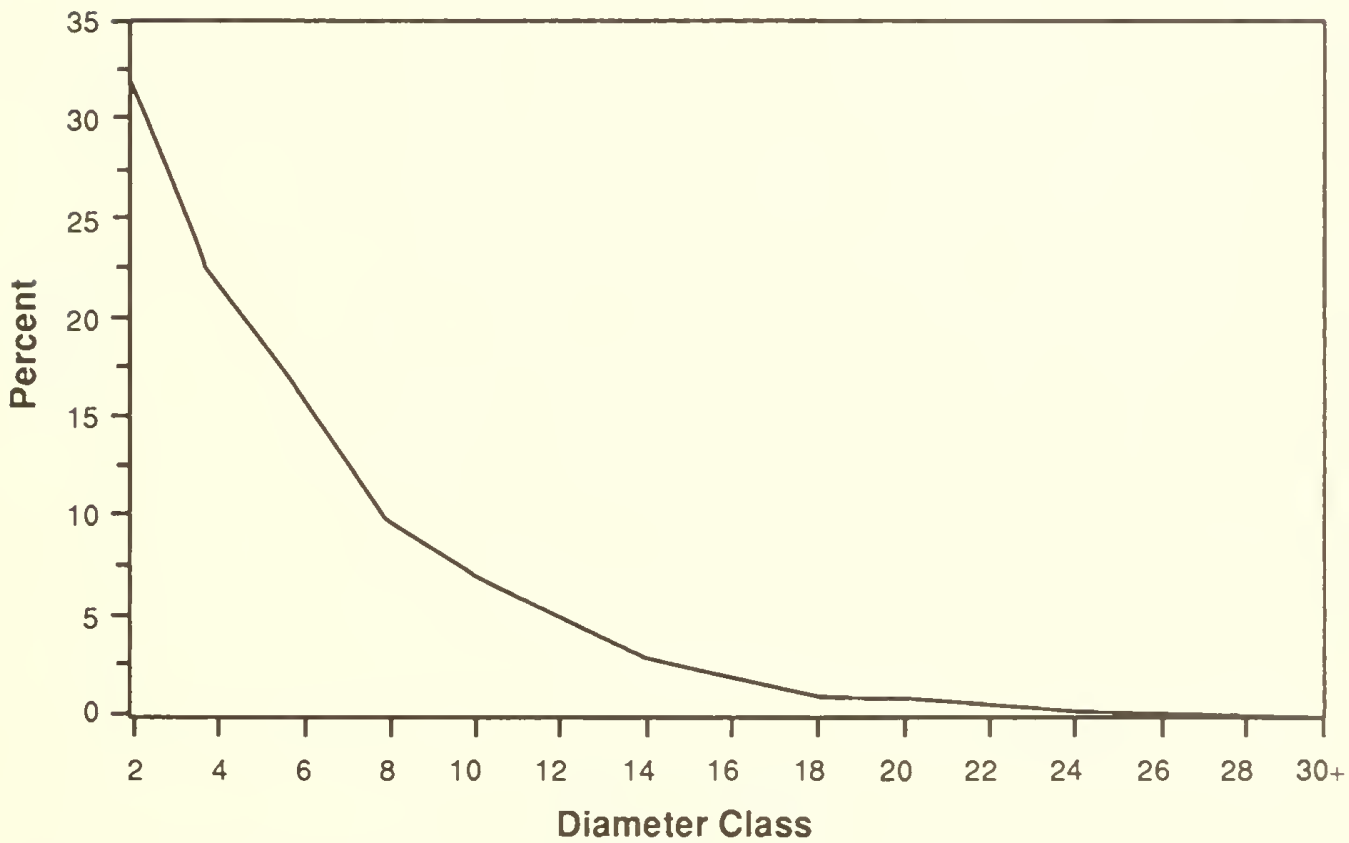

Figure 14-Distribution of trees on woodland outside National Forests by diameter at root collar class in New Mexico, 1987. 
The average woodland acre supports 457 cubic feet of volume in woodland species. There are 844,000 acres supporting stands that contain more than 1,000 cubic feet (fig. 15). Of these high-volume stands, 92 percent contain pinyon. On the other hand, more than twothirds of the pure juniper stands contain fewer than 400 cubic feet per acre. Stands in the oak type are represented across all stand volume classes, but 30 percent contain less than 200 cubic feet per acre, while one-fourth of the oak stands support more than 1,000 cubic feet per acre.

Unlike their timber counterparts, the only merchantability standard that applies to woodland species is the ability of given users to convert standing trees into products useful for them. Thus, all of the material is potentially usable. In addition to the 2.6 billion cubic feet of live material potentially available, there is an additional 631 million cubic feet present in the form of dead wood (fig. 16). And all of it would qualify as fuelwood. Ironically, most of this dead material is contained in live trees, and 42 percent is in stands that support more than 1,000 cubic feet per acre.

One product that commonly comes from pinyon is Christmas trees. Criteria have been developed, based on height and form, for classifying pinyon into various Christmas-tree grades, and these standards were applied to each pinyon tallied. Of the 688 million pinyon trees represented in the inventory, 83 million met the minimum standards for Christmas trees. Most of these, some 61 million, were utility grade. About 20 million trees met the specifications for the more desirable standard grade, and just over 3 million made the premium class, which is the most desirable.

A common product generated from the juniper and oak species is fenceposts. Two classes are generally recognized-line and corner. Altogether, an estimated 112 million fenceposts could be harvested from the woodland acres. About two-thirds of these are line posts, while some 37 million are the more valuable corner variety.

Components of Change-Net annual growth per acre equals 5.1 cubic feet. This amounts to an annual increase of nearly 30 million cubic feet in woodland inventory. The most productive woodland sites are those on which oak predominates, and they are growing 11.5 cubic feet per acre per year. Stands in which pinyon is present are producing about 5.2 cubic feet per acre per year, while the juniper types are adding 2.3 cubic feet per acre annually. In total, the woodland inventory is increasing at a net annual rate of 1.1 percent.

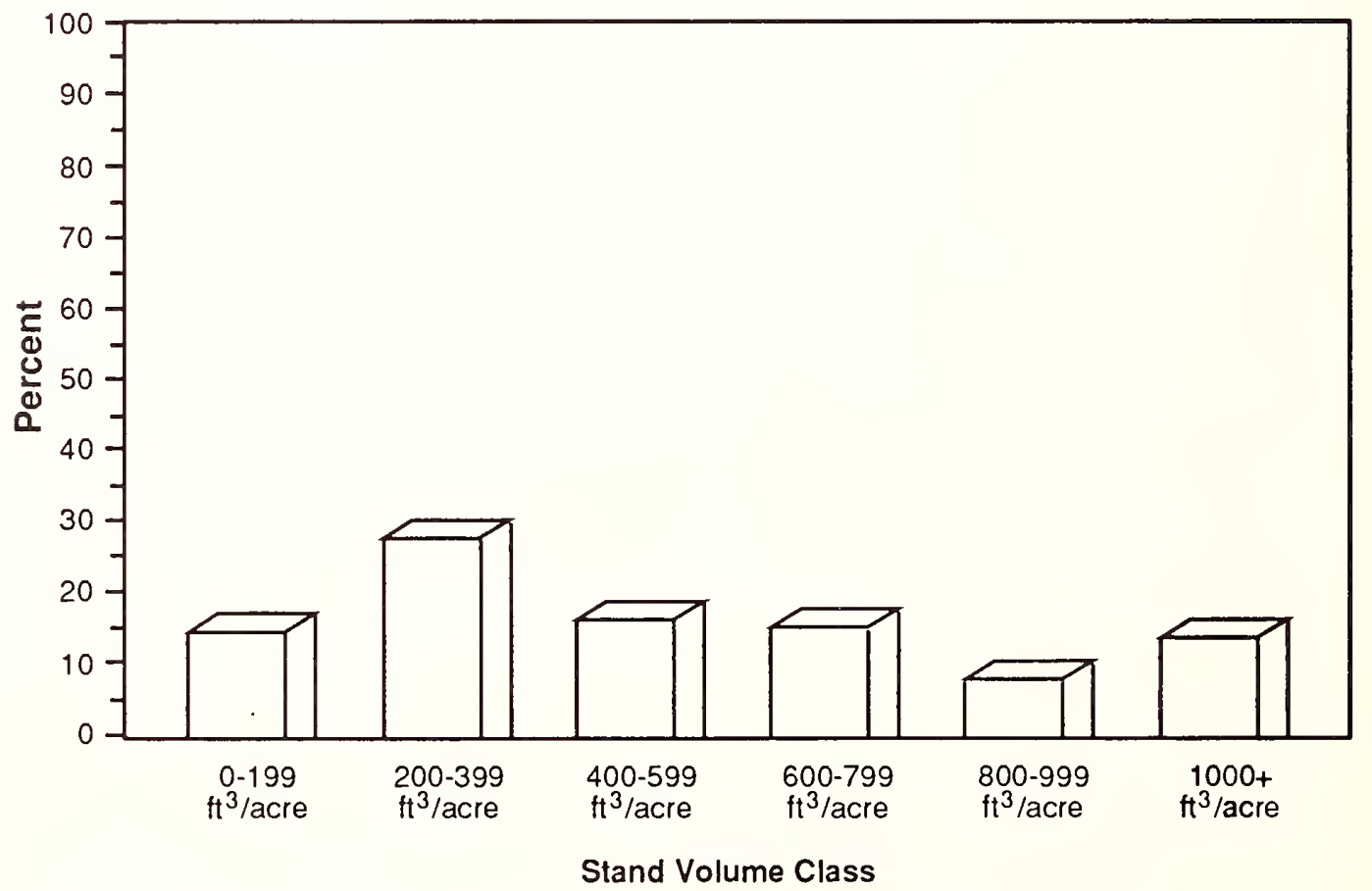

Figure 15-Distribution of woodland outside National Forests by stand-volume class in New Mexico, 1987. 


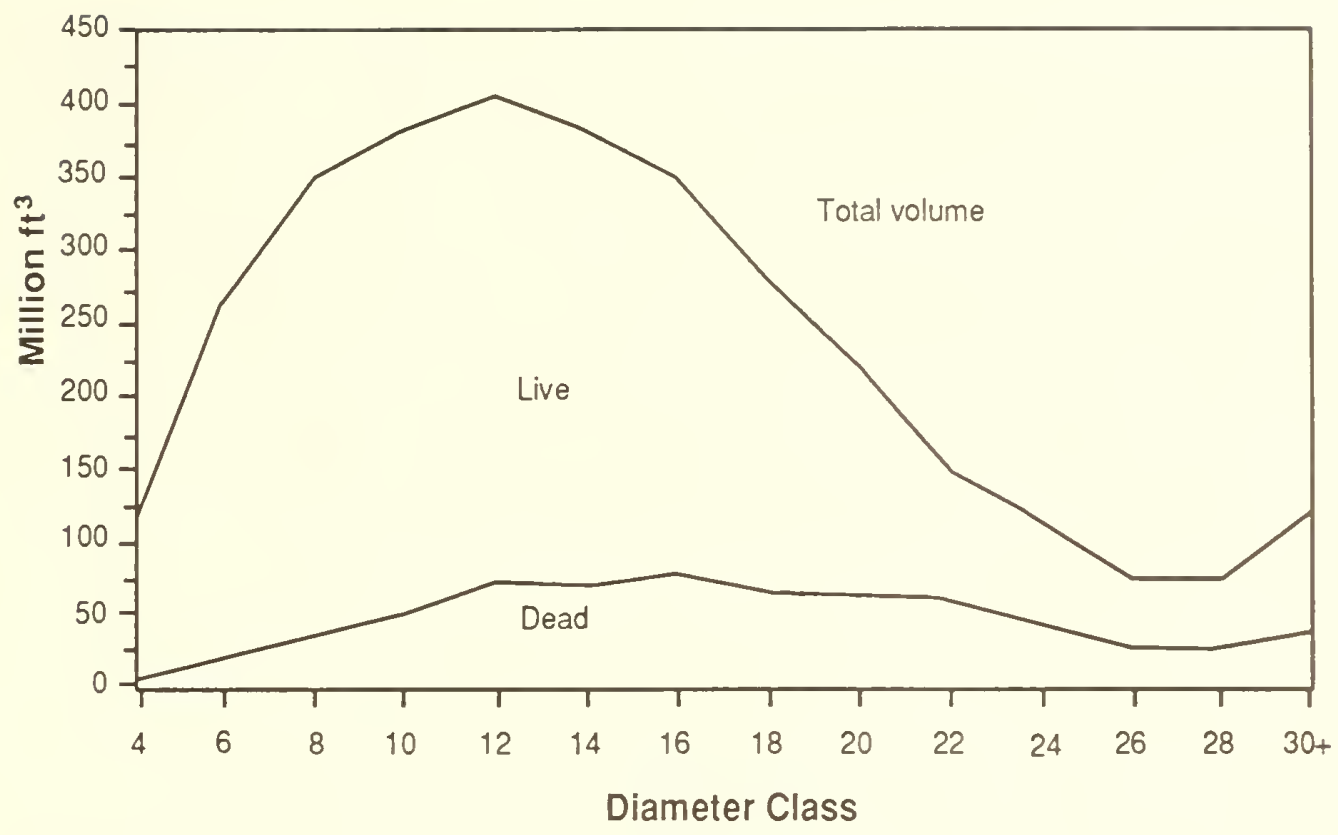

Figure 16-Distribution of volume on woodland outside National Forests by type of volume and diameter at root collar class in New Mexico, 1987.

\section{HOW THE INVENTORY WAS CONDUCTED}

The inventory was designed to provide reliable statistics primarily at the State and sample area levels.

\section{Prefield}

Initial area estimates were based on the classification of 273,497 sample points systematically placed on the latest aerial photographs available. The sample points were summarized and grouped into strata for subsequent field sampling. The photo points, adjusted to meet known land areas, were used to compute area expansion factors for the sampling strata means.

Field

\section{Compilation}

Land classification and estimates of timberland and woodland characteristics and volume were based on observations and measurements recorded at 9,747 field sample locations, of which 1,171 were forested (fig. 17).

Sample trees for timberland were selected on a 5 -point cluster. Trees less than 5.0 inches d.b.h. were measured on a $1 / 300$-acre fixed radius plot. Trees 5.0 inches d.b.h. or larger were selected using a variable radius plot. A 20 basal area factor prism was used for ponderosa pine locations, while other timberland locations were measured using a 40 basal area factor prism. Sample trees for woodland were selected on a $1 / 10$-acre or a $1 / 5$-acre fixed radius plot for trees 3.0 inches d.r.c. and larger. Trees less than 3.0 inches d.r.c. were tallied on $1 / 300$-acre subplots.

All editing, computation, and tabulation of photo and field data are through application of customized software systems. Final estimates from these data were based on statistical summaries, a portion of which is included in this bulletin. Volume and defect were computed using the most appropriate equations, including those developed by Chojnacky (1985), Hann and Bare (1978), and Edminster (1977). 


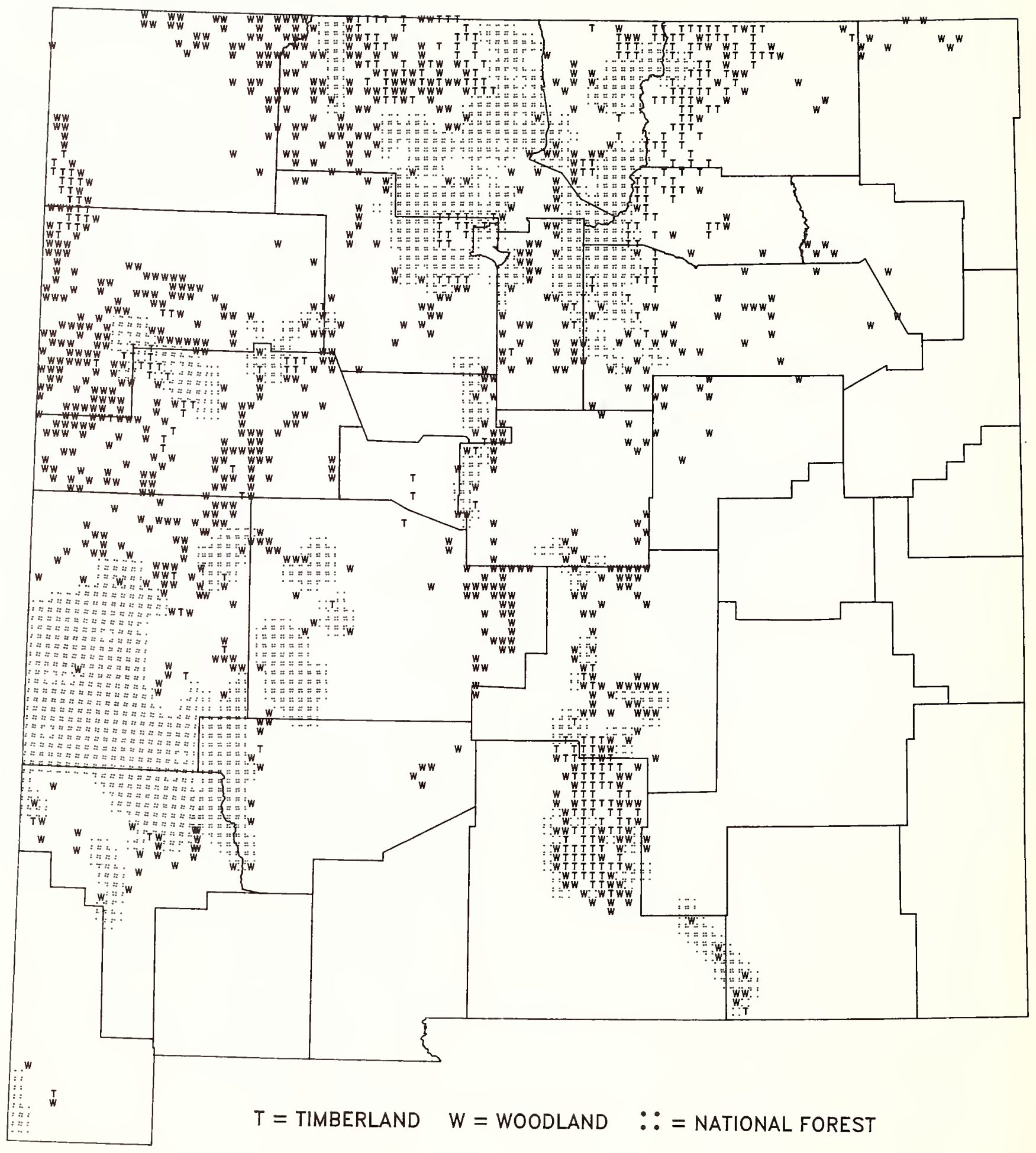

Figure 17-Distribution of timberland and woodland field locations outside National Forests in New Mexico, 1986 and 1987. 


\section{DATA RELIABILITY}

Individual cells within tables should be used with caution. Some are based on small sample sizes, which may result in high sampling errors. The standard error percentages shown in tables 2 and 3 were calculated at the 67 percent confidence level.

\section{TERMINOLOGY}

Acceptable trees-Growing-stock trees meeting specified standards of size and quality but not qualifying as desirable trees.

Area condition class-A classification of timberland reflecting the degree to which the site is being utilized by growing-stock trees and other conditions affecting current and prospective timber growth (see Stocking):

Class 10-Areas fully stocked with desirable trees and not overstocked.

Class 20-Areas fully stocked with desirable trees but overstocked with all live trees.

Class 30-Areas medium to fully stocked with desirable trees and with less than 30 percent of the area controlled by other trees, or inhibiting vegetation or surface conditions that will prevent occupancy by desirable trees, or both.

Class 40-Areas medium to fully stocked with desirable trees and with 30 percent or more of the area controlled by other trees, or conditions that ordinarily prevent $\propto$ ccupancy by desirable trees, or both.

Class 50-Areas poorly stocked with desirable trees but fully stocked with growing-stock trees.

Class 60-Areas poorly stocked with desirable trees but with medium to full stocking of growing-stock trees.

Class 70-Areas nonstocked or poorly stocked with desirable trees and poorly stocked with growing-stock trees.

Class 80-Low-risk old-growth stands.

Class 90-High-risk old-growth stands.

Nonstocked-Areas less than 10 percent stocked with growing-stock trees.

Basal area-The cross-sectional area of a tree expressed in square feet. For timber species the calculation is based on diameter at breast height (d.b.h.); for woodland species it is based on diameter at root collar (d.r.c.).

Christmas tree grade-Pinyon species are classified as Christmas trees using the following guidelines:

Premium-Excellent conical form with no gaps in branches and a straight bole.

Standard-Good conical form with small gaps in branches and bole slightly malformed. Utility-Conical in form with branches missing and bole bent or malformed.

Cull-Not meeting one of the above classifications or over 12 feet in height.

Cord-A pile of stacked wood equivalent to 128 cubic feet of wood and air space having standard dimensions of 4 by 4 by 8 feet.

Cull trees-Live trees that are unmerchantable now or prospectively (see Rough trees and Rotten trees).

Cull volume-Portions of a tree's volume that are not usable for wood products because of rot, missing or dead material, or other cubic-foot defect.

Deferred forest land-Forest lands within the National Forest System that are under study for possible inclusion in the Wilderness System.

Desirable trees-Growing-stock trees (1) having no serious defect in quality to limit present or prospective use for timber products, (2) of relatively high vigor, and (3) containing no pathogens that may result in death or serious deterioration within the next decade.

Diameter at breast height (d.b.h.)-Diameter of the stem measured at 4.5 feet above the ground.

Diameter at root collar (d.r.c.)-Diameter equivalent at the point nearest the ground line that represents the basal area of the tree stem or stems.

Diameter classes-Tree diameters, either d.b.h. or d.r.c., grouped into 2 -inch classes labeled by the midpoint of the class. 
Farmer/rancher-owned lands-Lands owned by a person who operates a farm or a ranch and who either does the work or directly supervises the work.

Fenceposts-Juniper and oak species are evaluated for post potential using the following criteria:

Line post-A 7-foot minimum length with 5 to 7 inches diameter at the butt, 2.5 inch minimum small end diameter, and reasonably straight and solid.

Corner post-An 8-foot minimum length with 7 to 9 inches diameter at the butt, 2.5 inch minimum small end diameter, and reasonably straight and solid.

Forest industry lands-Lands owned by companies or individuals operating a primary woodprocessing plant.

Forest lands - Lands at least 10 percent stocked by forest trees of any size, including lands that formerly had such tree cover and that will be naturally or artificially regenerated. The minimum area for classification of forest land is 1 acre. Roadside, streamside, and shelterbelt strips of timber must have a crown width at least 120 feet wide to qualify as forest land. Unimproved roads and trails, streams, and clearings in forest areas are classified as forest if less than 120 feet wide.

Forest trees-Woody plants having a well-developed stem or stems, usually more than 12 feet in height at maturity, with a generally well-defined crown.

Forest type-A classification of forest land based upon and named for the tree species presently forming a plurality of live-tree stocking.

Gross annual growth-The average annual increase in the net volume of trees during a specified period.

Growing-stock trees-Live sawtimber trees, poletimber trees, saplings, and seedlings of timber species meeting specified standards of quality and vigor; excludes cull trees.

Growing-stock volume-Net cubic-foot volume in live poletimber-size and sawtimber-size growing-stock trees from a 1-foot stump to a minimum 4-inch top (of central stem) outside bark or to the point where the central stem breaks into limbs.

Growth-See definition for Net annual growth.

Hardwood trees-Dicotyledonous trees, usually broad-leaved and deciduous.

High-risk old-growth stands-Timber stands over 100 years old in which the majority of the trees are not expected to survive more than 10 years.

Indian lands-Indian lands held in trust by the Federal Government.

Industrial wood-All commercial roundwood products except fuelwood.

Land area-The area of dry land and land temporarily or partially covered by water such as marshes, swamps, and river flood plains, streams, sloughs, estuaries, and canals less than 120 feet wide; and lakes, reservoirs, and ponds less than 1 acre in size.

Logging residues-The unused portions of growing-stock trees cut or killed by logging.

Low-risk old-growth stands-Timber stands over 100 years old in which the majority of the trees are expected to survive more than 10 years.

Miscellaneous Federal lands-Lands administered by Federal agencies other than the Forest Service, U.S. Department of Agriculture, or Bureau of Land Management, U.S. Department of the Interior.

Mortality_The net volume of growing-stock trees that have died from natural causes during a specified period.

National Forest lands-Public lands administered by the Forest Service, U.S. Department of Agriculture.

National Resource lands-Public lands administered by the Bureau of Land Management, U.S. Department of the Interior.

Net annual growth-Gross annual growth minus average annual mortality.

Net dead volume-Total net volume of dead trees plus the net volume of dead material in live trees.

Net volume in board feet-The gross board-foot volume in the sawlog portion of growingstock trees, less deductions for cull volume. 
Net volume in cubic feet-Gross cubic-foot volume in the merchantable portion of trees less deductions for cull volume. For timber species, volume is computed for the merchantable stem from a 1-foot stump to a minimum 4-inch top diameter outside bark (d.o.b.), or to the point where the central stem breaks into limbs. For woodland species, volume is computed outside bark (o.b.) for all woody material above d.r.c. that is larger than 1.5 inches d.o.b.

Nonforest lands-Lands that do not currently qualify as forest land.

Nonindustrial private-All private ownerships except forest industry.

Nonstocked areas-Forest land less than 10 percent stocked with live trees.

Old-growth stands - Stands of timber species over 100 years old.

Other private lands-Privately owned lands other than forest industry or farmer-owned.

Other public lands-Public lands administered by agencies other than the Forest Service, U.S. Department of Agriculture.

Other removals-The net volume of growing-stock trees removed from the inventory by cultural operations such as timber-stand improvement, by land clearing, and by changes in land use, such as a shift to wilderness.

Poletimber stands-Stands at least 10 percent stocked with growing-stock trees, in which half or more of the stocking is sawtimber or poletimber trees or both, with poletimber stocking exceeding that of sawtimber (see definition for Stocking).

Poletimber trees-Live trees of timber species at least 5 inches d.b.h. but smaller than sawtimber size.

Potential growth-The average net annual cubic-foot growth per acre at culmination of mean annual growth attainable in fully stocked natural stands.

Primary wood-processing plants-Plants using roundwood products such as sawlogs, pulpwood bolts, veneer logs, and so forth.

Productivity class-A classification of forest land that reflects biological potential. For timberlands the index used is the potential net annual growth at culmination of mean annual increment in fully stocked natural stands. For woodland, characteristics that affect the land's ability to produce wood, such as soil depth and aspect, are used. Furthermore, woodland is classified as high site where sustained wood production is likely, or low site where the continuous production of wood is unlikely.

Removals-The net volume of growing-stock trees removed from the inventory by harvesting, cultural operations, land clearings, or changes in land use.

Reserved forest land-Forest land withdrawn from tree utilization through statute or administrative designation.

\section{Residues:}

Coarse residues-Plant residues suitable for chipping, such as slabs, edgings, and ends. Fine residues-Plant residues not suitable for chipping, such as sawdust, shavings, and veneer clippings.

Plant residues-Wood materials from primary manufacturing plants that are not used for any product.

Rotten trees-Live poletimber or sawtimber trees with more than 67 percent of their total volume cull (cubic-foot) and with more than half of the cull volume attributable to rotten or missing material.

Rough trees-Live poletimber or sawtimber trees with more than 67 percent of their total volume cull (cubic-foot) and with less than half of the cull volume attributable to rotten or missing material.

Roundwood-Logs, bolts, or other round sections cut from trees.

Salvable dead trees-Standing or down dead trees that are currently merchantable by regional standards.

Saplings-Live trees of timber species 1 to 4.9 inches d.b.h. or woodland species 1 to 2.9 inches d.r.c.

Sapling and seedling stands-Timberland stands at least 10 percent stocked on which more than half of the stocking is saplings or seedlings or both. 
Sawlog portion-That part of the bole of sawtimber trees between a 1 -foot stump and the sawlog top.

Sawlog top-The point on the bole of sawtimber trees above which a sawlog cannot be produced. The minimum sawlog top is 7 inches d.o.b. for softwoods and 9 inches d.o.b. for hardwoods.

Sawtimber stands-Stands at least 10 percent stocked with growing-stock trees, with half or more of total stocking in sawtimber or poletimber trees, and with sawtimber stocking at least equal to poletimber stocking.

Sawtimber trees-Live trees of timber species meeting regional size and defect specifications. Softwood trees must be at least 9 inches d.b.h. and hardwood trees 11 inches d.b.h.

Sawtimber volume-Net volume in board feet of the sawlog portion of live sawtimber trees.

Seedlings-Established live trees of timber species less than 1 inch d.b.h. or woodland species less than 1 inch d.r.c.

Softwood trees-Monocotyledonous trees, usually evergreen, having needle or scalelike leaves.

Standard error-An expression of the degree of confidence that can be placed on an estimated total or average obtained by statistical sampling methods. Standard errors do not include technique errors that could occur in photo classification of areas, field measurements, or compilation of data.

Stand-size classes-A classification of forest land based on the predominant size of trees present (see Sawtimber stands, Poletimber stands, and Sapling and seedling stands).

State, county, and municipal lands-Lands administered by States, counties, and local public agencies, or lands leased by these governmental units for more than 50 years.

Stocking-An expression of the extent to which growing space is effectively utilized by present or potential growing-stock trees of timber species.

Timberland-Forest land where timber species make up at least 10 percent stocking.

Timber species-Tree species traditionally used for industrial wood products. In the Rocky Mountain States, these include aspen and cottonwood hardwood species and all softwood species except pinyon and juniper.

Timber stand improvement-Treatments such as thinning, pruning, release cutting, girdling, weeding, or poisoning of unwanted trees aimed at improving growing conditions for the remaining trees.

Upper-stem portion-That part of the main stem or fork of sawtimber trees above the sawlog top to a minimum top diameter of 4 inches outside bark or to the point where the main stem or fork breaks into limbs.

Water-Streams, sloughs, estuaries, and canals more than 120 feet wide, and lakes, reservoirs, and ponds more than 1 acre in size at mean high water level.

Wilderness-An area of undeveloped land currently included in the Wilderness System, managed so as to preserve its natural conditions and retain its primeval character and influence.

Woodland-Forest land where timber species make up less than 10 percent stocking.

Woodland species-Tree species not usually converted into industrial wood products. Common uses are fuelwood, fenceposts, and Christmas trees.

\section{REFERENCES}

Chojnacky, David C. 1985. Pinyon-juniper volume equations for the Central Rocky Mountain States. Res. Pap. INT-339. Ogden, UT: U.S. Department of Agriculture, Forest Service, Intermountain Forest and Range Experiment Station. 27 p.

Edminster, Carleton B. 1977. Past diameters and gross volumes of plains cottonwood in eastern Colorado. Res. Note RM-351. Fort Collins, CO: U.S. Department of Agriculture, Forest Service, Rocky Mountain Forest and Range Experiment Station. 4 p.

Hann, David W.; Bare, Bruce B. 1978. Comprehensive tree volume equations for major species of New Mexico and Arizona: II. Tables for unforked trees. Res. Pap. INT-210. Ogden, UT: U.S. Department of Agriculture, Forest Service, Intermountain Forest and Range Experiment Station. 127 p. 
Table 1--Total land and water area by ownership class in New Mexico, 1987

\begin{tabular}{|c|c|}
\hline Ownership class & Area \\
\hline & - - Acres - - \\
\hline \multicolumn{2}{|l|}{ Land: } \\
\hline $\begin{array}{l}\text { Public: } \\
\text { National Forest }\end{array}$ & $9,325,185$ \\
\hline $\begin{array}{l}\text { Other public: } \\
\text { Bureau of Land Management } \\
\text { National Parks } 1 \\
\text { Miscellaneous Federal } \\
\text { State } \\
\text { County and municipal }\end{array}$ & $\begin{array}{r}12,851,491 \\
251,010 \\
3,438,865 \\
9,681,981 \\
16,541 \\
\end{array}$ \\
\hline Total other public & $26,239,888$ \\
\hline Total public & $35,565,073$ \\
\hline $\begin{array}{l}\text { Private: } \\
\text { Indian } \\
\text { Other private }\end{array}$ & $\begin{array}{r}7,934,493 \\
34,211,179 \\
\end{array}$ \\
\hline Total private & $42,145,672$ \\
\hline Total land area & $77,710,745$ \\
\hline Census water & 108,474 \\
\hline Total land and water ${ }^{2}$ & $77,819,219$ \\
\hline
\end{tabular}

${ }^{1}$ Not included with miscellaneous Federal, a component of other public, for purpose of clarity. These lands are reserved and are included in tables 1 , 2 , and 4 only.

2U.S. Department of Commerce, Bureau of Census. Area measurement reports, GE-20 No. 1, 22 p., 1970, updated to account for changes in inland water estimates obtained from the USDA Soil Conservation Service's National Resource Inventory, 1982. 
Table 2--Area of forest land outside National Forests with percent standard error in New Mexico, 1987

\begin{tabular}{lcc}
\hline \multicolumn{1}{c}{ Item } & Acres & $\begin{array}{c}\text { Percent } \\
\text { standard } \\
\text { error }\end{array}$ \\
\hline Timberland & $2,099,292$ & \pm 3.6 \\
Woodland & $5,741,451$ & \pm 2.6 \\
$\begin{array}{l}\text { Reserved forest land: }{ }^{1} \\
\text { Timberland } \\
\text { Woodland }\end{array}$ & 161,422 & \\
\multicolumn{1}{|c|}{ Total forest land ${ }^{2}$} & $8,117,198$ & \\
\hline
\end{tabular}

${ }^{1}$ Reserved land areas are estimated from aerial photos without field verification; therefore, standard errors are not calculated.

${ }^{2}$ On this and all following tables, totals may vary due to rounding.

Table 3--Net volume, net annual growth, and annual mortality of growing stock and sawtimber on forest land outside National Forests with percent standard error in New Mexico

All species

\begin{tabular}{|c|c|c|c|}
\hline Forest land & Item & Volume & $\begin{array}{l}\text { Percent } \\
\text { standard } \\
\text { error }\end{array}$ \\
\hline \multirow[t]{3}{*}{ Timberland: } & $\begin{array}{l}\text { Net volume, } 1987 \text { : } \\
\text { Growing stock (M cubic feet) } \\
\text { Sawtimber ( } M \text { board feet) } \\
\text { Sawtimber }{ }^{2} \text { ( } M \text { board feet) }\end{array}$ & $\begin{array}{l}2,081,464 \\
7,910,338 \\
6,564,142 \\
\end{array}$ & $\begin{array}{l} \pm 5.9 \\
\pm 6.4 \\
\pm 6.4 \\
\end{array}$ \\
\hline & $\begin{array}{l}\text { Net annual growth, } 1986 \text { : } \\
\text { Growing stock ( } M \text { cubic feet) } \\
\text { Sawtimber ( } M \text { board feet) } \\
\text { Sawtimber }{ }^{2} \text { ( } M \text { board feet) }\end{array}$ & $\begin{array}{r}54,564 \\
248,311 \\
205,309 \\
\end{array}$ & $\begin{array}{r} \pm 9.3 \\
\pm 10.3 \\
\pm 9.7 \\
\end{array}$ \\
\hline & $\begin{array}{l}\text { Annual mortality, 1986: } \\
\text { Growing stock (M cubic feet) } \\
\text { Sawtimber (M board feet) } \\
\text { Sawtimber }{ }^{2} \text { (M board feet) }\end{array}$ & $\begin{array}{r}6,221 \\
19,351 \\
15,224 \\
\end{array}$ & $\begin{array}{l} \pm 56.6 \\
\pm 52.1 \\
\pm 49.9 \\
\end{array}$ \\
\hline Woodland: & $\begin{array}{l}\text { Volume, } 1987 \text { (M cubic feet) } \\
\text { Growth, } 1986 \text { (M cubic feet) } \\
\text { Mortality, } 1986 \text { (M cubic feet) }\end{array}$ & $\begin{array}{r}2,693,813 \\
29,526 \\
353\end{array}$ & $\begin{array}{r} \pm 3.7 \\
\pm 4.1 \\
\pm 51.2\end{array}$ \\
\hline
\end{tabular}

${ }^{1}$ International $\frac{1}{4}$-inch rule.

${ }^{2}$ Scribner rule. 
Table 4--Total land area outside National Forests by major land class and ownership class in New Mexico, 1987

\begin{tabular}{|c|c|c|c|}
\hline \multirow{2}{*}{ Land class } & \multicolumn{2}{|c|}{ Ownership class } & \multirow[b]{2}{*}{ Total } \\
\hline & $\begin{array}{l}\text { Other } \\
\text { public }\end{array}$ & Private & \\
\hline & ----- & - - Acres - & ----- \\
\hline $\begin{array}{l}\text { Timberland: } \\
\text { Reserved } \\
\text { Nonreserved }\end{array}$ & $\begin{array}{r}53,414 \\
135,235 \\
\end{array}$ & $\begin{array}{r}108,008 \\
1,964,057 \\
\end{array}$ & $\begin{array}{r}161,422 \\
2,099,292 \\
\end{array}$ \\
\hline Total & 188,649 & $2,072,065$ & $2,260,714$ \\
\hline $\begin{array}{l}\text { Woodland: } \\
\text { Reserved } \\
\text { Nonreserved }\end{array}$ & $\begin{array}{r}55,635 \\
1,736,185 \\
\end{array}$ & $\begin{array}{r}59,563 \\
4,005,266 \\
\end{array}$ & $\begin{array}{r}115,198 \\
5,741,451 \\
\end{array}$ \\
\hline Total & $1,791,820$ & $4,064,829$ & $5,856,649$ \\
\hline $\begin{array}{l}\text { Total forest land: } \\
\text { Reserved } \\
\text { Nonreserved }\end{array}$ & $\begin{array}{r}109,049 \\
1,871,420 \\
\end{array}$ & $\begin{array}{r}167,571 \\
5,969,323 \\
\end{array}$ & $\begin{array}{r}276,620 \\
7,840,743 \\
\end{array}$ \\
\hline Total & $1,980,469$ & $6,136,894$ & $8,117,363$ \\
\hline Nonforest land & $24,259,419$ & $36,008,778$ & $60,268,197$ \\
\hline Total land area & $26,239,888$ & $42,145,672$ & $68,385,560$ \\
\hline
\end{tabular}




\section{TIMBERI_AND TABLES}

Table 5--Area of timberland outside National Forests by forest type, stand-size class, and productivity class in New Mexico, 1987

Forest type and

stand-size class
Productivity class

$\begin{array}{llll}85-119 & 50-84 & 20-49 & 0-19\end{array}$ acres

Total

cores
Douglas-fir:

Sawtimber

Poletimber

Sapling and seedling

Nons tocked

Tota 1

Ponderosa pine:

Sawtimber

Poletimber

Sapling and seedling

Nons tocked

Total

Spruce-fir:

Sawtimber

Poletimber

Sapling and seedling

Nonstocked

Tota 1

White fir:

Sawtimber

Poletimber

Sapling and seedling Nonstocked

Total

\begin{tabular}{rrrrr}
6,014 & 94,383 & 164,848 & -- & 265,245 \\
-- & 28,659 & 44,176 & -- & 72,835 \\
-- & -- & -- & -- & -- \\
-- & 13,486 & 24,865 & -- & 38,351 \\
\hline 6,014 & 136,528 & 233,889 & -- & 376,431 \\
\hline
\end{tabular}

\begin{tabular}{rrrrr}
-- & 90,864 & 943,058 & - & $1,033,922$ \\
-- & -- & 186,285 & -- & 186,285 \\
-- & -- & 12,347 & -- & 12,347 \\
-- & -- & 21,239 & -- & 21,239 \\
\hline-- & 90,864 & $1,162,929$ & $\ldots$ & $1,253,793$ \\
\hline
\end{tabular}

\begin{tabular}{rrrrr}
-- & 36,445 & 29,814 & -- & 66,259 \\
-- & 23,847 & 24,131 & -- & 47,978 \\
-- & -- & -- & -- & -- \\
-- & 7,949 & -- & -- & 7,949 \\
\hline-- & 68,241 & 53,945 & -- & 122,186 \\
\hline
\end{tabular}

\begin{tabular}{rrrrr}
21,038 & 87,291 & 31,103 & -- & 139,432 \\
1,993 & -- & 7,949 & -- & 9,942 \\
-- & -- & -- & -- & -- \\
-- & 5,626 & -- & $\ldots$ & 5,626 \\
\hline 23,031 & 92,917 & 39,052 & -- & 155,000 \\
\hline
\end{tabular}


Table 5 (Con.)

Forest type and

stand-size class

\begin{tabular}{cccc}
\multicolumn{3}{c}{ Productivity class } & $\begin{array}{r}\text { Total } \\
\text { acres }\end{array}$
\end{tabular}

- . . . . . . - Acres - . . . . . -

Spruce:

Sawtimber

Poletimber

Sapling and seedling

Nonstocked

Total

\begin{tabular}{rrrrr}
-- & 38,998 & 7,949 & -- & 46,947 \\
7,949 & 4,186 & 7,949 & -- & 20,084 \\
-- & -- & 7,949 & -- & 7,949 \\
-- & -- & -- & -- & -- \\
\hline 7,949 & 43,184 & 23,847 & -- & 74,980 \\
\hline \hline
\end{tabular}

Other softwoods:

Sawtimber

Poletimber

Sapling and seedling

Nonstocked

Total

\begin{tabular}{rrrrr}
-- & 6,014 & 7,575 & -- & 13,589 \\
-- & -- & -- & -- & -- \\
-- & -- & -- & -- & -- \\
-- & -- & -- & -- & -- \\
\hline-- & 6,014 & 7,575 & -- & 13,589 \\
\hline
\end{tabular}

Aspen:

Sawtimber

Poletimber

Sapling and seedling Nonstocked

Total

\begin{tabular}{rrrrr}
7,949 & 7,949 & 7,575 & -- & 23,473 \\
5,018 & 14,371 & 15,898 & -- & 35,287 \\
-- & 5,018 & 6,632 & -- & 11,650 \\
-- & -- & -- & -- & -- \\
\hline 12,967 & 27,338 & 30,105 & -- & 70,410 \\
\hline
\end{tabular}

Cottonwood:

Sawtimber

Poletimber

Sapling and seedling Nonstocked

\begin{tabular}{rrrrr}
-- & 24,954 & -- & -- & 24,954 \\
-- & -- & -- & -- & -- \\
-- & -- & -- & -- & -- \\
-- & 7,949 & -- & -- & 7,949 \\
\hline-- & 32,903 & -- & -- & 32,903 \\
\hline
\end{tabular}

Al1 types:

Sawtimber

Poletimber

Sapling and seedling

Nonstocked

\begin{tabular}{rrrrr}
35,001 & 386,898 & $1,191,922$ & -- & $1,613,821$ \\
14,960 & 71,063 & 286,388 & -- & 372,411 \\
-- & 5,018 & 26,928 & -- & 31,946 \\
-- & 35,010 & 46,104 & -- & 81,114 \\
\hline 49,961 & 497,989 & $1,551,342$ & -- & $2,099,292$
\end{tabular}


Table 6--Area of other publicly owned timberland by forest type, stand-size class, and productivity class in New Mexico, 1987

\begin{tabular}{|c|c|c|c|c|c|}
\hline \multirow{2}{*}{$\begin{array}{l}\text { Forest type and } \\
\text { stand-size class }\end{array}$} & \multicolumn{4}{|c|}{ Productivity class } & \multirow{2}{*}{$\begin{array}{l}\text { Total } \\
\text { acres }\end{array}$} \\
\hline & $85-119$ & $50-84$ & $20-49$ & $0-19$ & \\
\hline & ---- & --- & - Acres & -- & --- \\
\hline \multicolumn{6}{|l|}{ Douglas-fir: } \\
\hline Sawtimber & $=-$ & 5,603 & 6,132 & -- & 11,735 \\
\hline Poletimber & -- & -- & -- & -- & -- \\
\hline Sapling and seedling & -- & -- & -- & -- & -- \\
\hline Nons tocked & -- & -- & -- & -- & -- \\
\hline Total & - & 5,603 & 6,132 & -- & 11,735 \\
\hline \multicolumn{6}{|l|}{ Ponderosa pine: } \\
\hline Sawtimber & -- & -- & 85,779 & -- & 85,779 \\
\hline Poletimber & -- & -- & $=-$ & -- & $=-$ \\
\hline Sapling and seedling & -- & -- & -- & -- & -- \\
\hline Nonstocked & -- & -- & 941 & -- & 941 \\
\hline Total & -- & -- & 86,720 & -- & 86,720 \\
\hline \multicolumn{6}{|l|}{ Spruce-fir: } \\
\hline Sawtimber & -- & -- & -- & -- & -- \\
\hline Poletimber & -- & -- & 4,249 & -- & 4,249 \\
\hline Sapling and seedling & -- & -- & $=$ & -- & -- \\
\hline Nonstocked & -- & $=$ & -- & -- & -- \\
\hline Total & -- & - & 4,249 & -- & 4,249 \\
\hline \multicolumn{6}{|l|}{ White fir: } \\
\hline Sawtimber & 942 & 16,870 & 4,249 & -- & 22,061 \\
\hline Poletimber & -- & -- & -- & -- & -- \\
\hline Sapling and seedling & -- & - & -- & -- & -- \\
\hline Nonstocked & -- & - & -- & -- & -- \\
\hline Tota 1 & 942 & 16,870 & 4,249 & -- & 22,061 \\
\hline
\end{tabular}


Table 6 (Con.)

Forest type and

stand-size class

$\begin{array}{cccc}\text { Productivity class } & \begin{array}{r}\text { Total } \\ \text { acres }\end{array}\end{array}$

- - - . . . - - Acres - . . . . . -

Spruce:

Sawtimber

Poletimber

Sapling and seedling Nonstocked

Total

\begin{tabular}{rrrrr}
-- & -- & -- & -- & -- \\
-- & 4,186 & -- & -- & 4,186 \\
-- & -- & -- & -- & -- \\
-- & -- & -- & -- & -- \\
\hline-- & 4,186 & -- & -- & 4,186 \\
\hline
\end{tabular}

Other softwoods:

Sawt imber

Poletimber

Sapling and seedling

Nons tocked

Total

Aspen:

Sawtimber

Poletimber

Sapling and seedling Nonstocked

Total

Cottonwood:

Sawtimber

Poletimber

Sapling and seedling Nons tocked

Total

\begin{tabular}{lllll}
-- & -- & -- & -- & -- \\
-- & -- & -- & -- & -- \\
-- & -- & -- & -- & -- \\
-- & -- & -- & -- & -- \\
\hline-- & -- & -- & - & - \\
\hline
\end{tabular}

\begin{tabular}{lllll}
-- & -- & -- & -- & -- \\
-- & -- & -- & -- & -- \\
-- & -- & -- & -- & -- \\
-- & -- & -- & -- & -- \\
\hline-- & -- & -- & -- & -- \\
\hline
\end{tabular}

\begin{tabular}{rrrrr}
-- & 6,284 & -- & -- & 6,284 \\
-- & -- & -- & -- & -- \\
-- & -- & -- & -- & -- \\
-- & -- & -- & -- & -- \\
\hline-- & 6,284 & -- & -- & 6,284 \\
\hline
\end{tabular}

All types:

Sawtimber

Poletimber

Sapling and seedling Nons tocked

\begin{tabular}{rrrrr}
942 & 28,757 & 96,160 & -- & 125,859 \\
-- & 4,186 & 4,249 & -- & 8,435 \\
-- & -- & -- & -- & -- \\
-- & -- & 941 & -- & 941 \\
\hline 942 & 32,943 & 101,350 & -- & 135,235
\end{tabular}


Table 7--Area of privately owned timberland by forest type, stand-size class, and productivity class in New Mexico, 1987

Forest type and

stand-size class

\begin{tabular}{lccc}
\multicolumn{3}{c}{ Productivity class } & $\begin{array}{l}\text { Total } \\
\text { acres }\end{array}$
\end{tabular}

Douglas-fir:

Sawtimber

Poletimber

Sapling and seedling

Nonstocked

Total

Ponderosa pine:

Sawtimber

Poletimber

Sapling and seedling

Nonstocked

Total

Spruce-fir:

Sawtimber

Poletimber

Sapling and seedling

Nonstocked

Total

\begin{tabular}{rrrrr}
6,014 & 88,780 & 158,716 & -- & 253,510 \\
-- & 28,659 & 44,176 & -- & 72,835 \\
-- & -- & -- & -- & -- \\
-- & 13,486 & 24,865 & -- & 38,351 \\
\hline 6,014 & 130,925 & 227,757 & -- & 364,696 \\
\hline
\end{tabular}

\begin{tabular}{rrrrr}
-- & 90,864 & 857,279 & -- & 948,143 \\
-- & -- & 186,285 & -- & 186,285 \\
-- & -- & 12,347 & -- & 12,347 \\
-- & -- & 20,298 & -- & 20,298 \\
\hline
\end{tabular}

- $90,864 \quad 1,076,209 \quad--\quad 1,167,073$

\begin{tabular}{rrrrr}
-- & 36,445 & 29,814 & -- & 66,259 \\
-- & 23,847 & 19,882 & -- & 43,729 \\
-- & -- & -- & -- & -- \\
-- & 7,949 & -- & -- & 7,949 \\
\hline-- & 68,241 & 49,696 & -- & 117,937 \\
\hline
\end{tabular}

White fir:

Sawtimber

Poletimber

Sapling and seedling

Nonstocked

Total

\begin{tabular}{rrrrr}
20,096 & 70,421 & 26,854 & -- & 117,371 \\
1,993 & -- & 7,949 & -- & 9,942 \\
-- & -- & -- & -- & -- \\
-- & 5,626 & -- & -- & 5,626 \\
\hline 22,089 & 76,047 & 34,803 & -- & 132,939 \\
\hline
\end{tabular}

(con.) 
Forest type and

stand-size class

\begin{tabular}{cccc}
\multicolumn{3}{c}{ Productivity class } & $\begin{array}{l}\text { Total } \\
\text { acres }\end{array}$
\end{tabular}

Spruce:

Sawtimber

Poletimber

Sapling and seedling

Nons tocked

Tota 1

Other softwoods:

Sawtimber

Poletimber

Sapling and seedling

Nons tocked

Total

Aspen:

Sawtimber

Poletimber

Sapling and seedling

Nons tocked

Total

\begin{tabular}{rrrrr}
-- & 38,998 & 7,949 & -- & 46,947 \\
7,949 & -- & 7,949 & -- & 15,898 \\
-- & -- & 7,949 & -- & 7,949 \\
-- & -- & -- & -- & -- \\
\hline 7,949 & 38,998 & 23,847 & -- & 70,794 \\
\hline
\end{tabular}

\begin{tabular}{rrrrr}
-- & 6,014 & 7,575 & -- & 13,589 \\
-- & -- & -- & -- & -- \\
-- & -- & -- & -- & -- \\
-- & -- & -- & -- & -- \\
\hline-- & 6,014 & 7,575 & -- & 13,589 \\
\hline
\end{tabular}

\begin{tabular}{rrrrr}
7,949 & 7,949 & 7,575 & -- & 23,473 \\
5,018 & 14,371 & 15,898 & -- & 35,287 \\
-- & 5,018 & 6,632 & -- & 11,650 \\
-- & -- & -- & -- & -- \\
\hline 12,967 & 27,338 & 30,105 & -- & 70,410 \\
\hline
\end{tabular}

Cottonwood:

Sawtimber

Poletimber

Sapling and seedling Nonstocked

Total

\begin{tabular}{rrrrr}
-- & 18,670 & -- & -- & 18,670 \\
-- & -- & -- & -- & -- \\
-- & -- & -- & -- & -- \\
-- & 7,949 & -- & -- & 7,949 \\
\hline-- & 26,619 & -- & -- & 26,619 \\
\hline
\end{tabular}

Al1 types:

Sawtimber

Poletimber

Sapling and seedling

Nonstocked

Total

\begin{tabular}{rrrrr}
34,059 & 358,141 & $1,095,762$ & -- & $1,487,962$ \\
14,960 & 66,877 & 282,139 & -- & 363,976 \\
-- & 5,018 & 26,928 & -- & 31,946 \\
-- & 35,010 & 45,163 & -- & 80,173 \\
\hline 49,019 & 465,046 & $1,449,992$ & -- & $1,964,057$
\end{tabular}


Table 8--Area of timberland outside National Forests by stand volume and ownership class in New Mexico, 1987

\begin{tabular}{|c|c|c|c|}
\hline \multirow{2}{*}{ Stand volume per acrel } & \multicolumn{2}{|c|}{ Ownership class } & \multirow[b]{2}{*}{ Total } \\
\hline & $\begin{array}{l}\text { Other } \\
\text { public }\end{array}$ & Private & \\
\hline & ---- & - - Acres - & --- \\
\hline $\begin{array}{l}\text { Less than } 1,500 \text { board feet } \\
1,500 \text { to } 4,999 \text { board feet } \\
5,000 \text { to } 9,999 \text { board feet } \\
10,000 \text { board feet or more }\end{array}$ & $\begin{array}{r}29,929 \\
78,916 \\
26,390 \\
- \\
\end{array}$ & $\begin{array}{l}570,266 \\
931,663 \\
334,331 \\
127,797 \\
\end{array}$ & $\begin{array}{r}600,195 \\
1,010,579 \\
360,721 \\
127,797 \\
\end{array}$ \\
\hline All classes & 135,235 & $1,964,057$ & $2,099,292$ \\
\hline
\end{tabular}

${ }^{1}$ International $\frac{1}{4}-i n c h$ rule. 

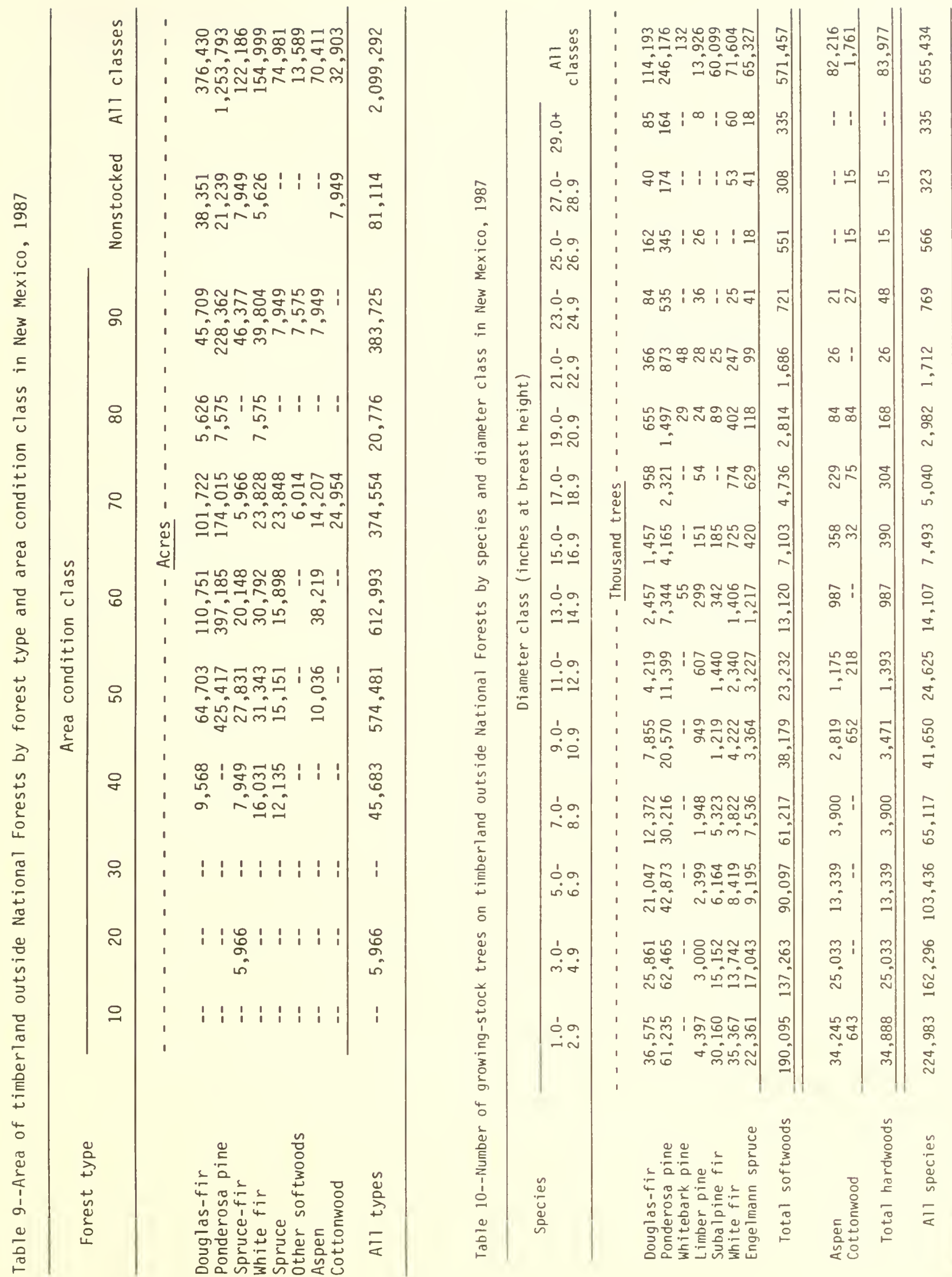
Table 11--Number of cull and salvable dead trees on timberland outside National Forests by ownership class, and softwoods and hardwoods in New Mexico, 1987

Ownership class and species group

Cull trees

Rough Rotten Total

Salvable dead trees

Total

- . - . - Thousand trees

Other public:

Softwoods

Hardwoods

Total

\begin{tabular}{rrrrr}
-- & 53 & 53 & 910 & 963 \\
-- & -- & -- & 644 & 644 \\
\hline-- & 53 & 53 & 1,554 & 1,607 \\
\hline
\end{tabular}

Private:

Softwoods

Hardwoods

\begin{tabular}{rrrrr}
918 & 601 & 1,519 & 15,800 & 17,319 \\
426 & 1,666 & 2,092 & 8,295 & 10,387 \\
\hline 1,344 & 2,267 & 3,611 & 24,095 & 27,706 \\
\hline
\end{tabular}

Total:

Softwoods

Hardwoods

\begin{tabular}{rrrrr}
918 & 654 & 1,572 & 16,710 & 18,282 \\
426 & 1,666 & 2,092 & 8,939 & 11,031 \\
\hline \multirow{2}{*}{1,344} & 2,320 & 3,664 & 25,649 & 29,313
\end{tabular}


Table 12--Net volume of growing stock on timberland outside National Forests by ownership class, forest type, and stand-size class in New Mexico, 1987

\begin{tabular}{|c|c|c|c|c|c|c|}
\hline \multirow[b]{2}{*}{ Ownership class } & \multirow[b]{2}{*}{ Forest type } & \multicolumn{4}{|c|}{ Stand-size class } & \multirow[b]{2}{*}{$\begin{array}{c}\text { All } \\
\text { classes }\end{array}$} \\
\hline & & Sawtimber & Poletimber & $\begin{array}{l}\text { Sapling/ } \\
\text { seedling }\end{array}$ & Nons tocked & \\
\hline
\end{tabular}

Other public:

Douglas-fir
Ponderosa pine
Spruce-fir
White fir
Spruce
Other softwoods
Aspen
Cottonwood

A11 types

Private:

Douglas-fir
Ponderosa pine
Spruce-fir
White fir
Spruce
Other softwoods
Aspen
Cottonwood
$\quad$ All types

Total:

Douglas-fir
Ponderosa pine
Spruce-fir
White fir
Spruce
Other softwoods
Aspen
Cottonwood

A11 types

\begin{tabular}{rrrrr}
23,883 & -- & -- & -- & 23,883 \\
47,341 & -- & -- & -- & 47,341 \\
-- & 3,318 & -- & -- & 3,318 \\
33,342 & -- & -- & -- & 33,342 \\
-- & 11,291 & -- & -- & 11,291 \\
-- & -- & -- & -- & -- \\
-- & -- & -- & -- & -- \\
10,987 & -- & - & -- & 10,987 \\
\hline 115,553 & 14,609 & - & -- & 130,162 \\
\hline
\end{tabular}

\begin{tabular}{rrrrr}
307,455 & 60,110 & -- & 5,671 & 373,236 \\
776,423 & 114,180 & 254 & 2,063 & 892,920 \\
98,835 & 90,393 & -- & 1,674 & 190,902 \\
230,681 & 3,853 & -- & 1,315 & 235,849 \\
129,657 & 19,128 & 1,369 & -- & 150,154 \\
20,981 & -- & -- & -- & 20,981 \\
40,036 & 33,217 & 2,271 & -- & 75,524 \\
11,736 & -- & -- & - & 11,736 \\
\hline $1,615,804$ & 320,881 & 3,894 & 10,723 & $1,951,302$ \\
\hline
\end{tabular}

\begin{tabular}{rrrrr}
331,338 & 60,110 & -- & 5,671 & 397,119 \\
823,764 & 114,180 & 254 & 2,063 & 940,261 \\
98,835 & 93,711 & -- & 1,674 & 194,220 \\
264,023 & 3,853 & -- & 1,315 & 269,191 \\
129,657 & 30,419 & 1,369 & -- & 161,445 \\
20,981 & -- & -- & -- & 20,981 \\
40,036 & 33,217 & 2,271 & -- & 75,524 \\
22,723 & -- & -- & -- & 22,723 \\
\hline $1,731,357$ & 335,490 & 3,894 & 10,723 & $2,081,464$
\end{tabular}


Table 13--Net volume of sawtimber (International 1 -inch rule) on timberland outside National Forests by ownership class, forest type, and stand-size class in New Mexico, 1987

\begin{tabular}{|c|c|c|c|c|c|c|}
\hline \multirow[b]{2}{*}{ Ownership class } & \multirow[b]{2}{*}{ Forest type } & \multicolumn{4}{|c|}{ Stand-size class } & \multirow[b]{2}{*}{$\begin{array}{c}\text { All } \\
\text { classes }\end{array}$} \\
\hline & & Sawtimber & Poletimber & $\begin{array}{l}\text { Sapling/ } \\
\text { seedling }\end{array}$ & Nonstocked & \\
\hline
\end{tabular}

- - - - Thousand board feet, International 1 -inch rule - - - - -

Other public:

Douglas-fir
Ponderosa pine
Spruce-fir
White fir
Spruce
Other softwoods
Aspen
Cottonwood

All types

Private:

Douglas-fir
Ponderosa pine
Spruce-fir
White fir
Spruce
Other softwoods
Aspen
Cottonwood

All types

Total:

\begin{tabular}{rrrrr}
85,385 & -- & -- & -- & 85,385 \\
211,908 & -- & -- & -- & 211,908 \\
-- & 5,792 & -- & -- & 5,792 \\
103,637 & -- & -- & -- & 103,637 \\
-- & 27,141 & -- & -- & 27,141 \\
-- & -- & -- & -- & -- \\
-- & -- & -- & -- & -- \\
39,373 & -- & -- & -- & 473,236 \\
\hline 440,303 & 32,933 & -- & -373 \\
\hline
\end{tabular}

\begin{tabular}{rrrrr}
$1,168,501$ & 89,017 & -- & 30,040 & $1,287,558$ \\
$3,454,489$ & 228,395 & 1,031 & 11,192 & $3,695,107$ \\
383,714 & 205,804 & -- & 4,655 & 594,173 \\
956,317 & 6,842 & -- & 6,024 & 969,183 \\
514,707 & 36,971 & 7,047 & -- & 558,725 \\
74,242 & -- & -- & -- & 74,242 \\
161,690 & 56,879 & -- & -- & 218,569 \\
39,545 & -- & -- & -- & 39,545 \\
\hline $6,753,205$ & 623,908 & 8,078 & 51,911 & $7,437,102$ \\
\hline
\end{tabular}

\begin{tabular}{rrrrr}
$1,253,886$ & 89,017 & -- & 30,040 & $1,372,943$ \\
$3,666,397$ & 228,395 & 1,031 & 11,192 & $3,907,015$ \\
383,714 & 211,596 & -- & 4,655 & 599,965 \\
$1,059,954$ & 6,842 & -- & 6,024 & $1,072,820$ \\
514,707 & 64,112 & 7,047 & -- & 585,866 \\
74,242 & -- & -- & -- & 74,242 \\
161,690 & 56,879 & -- & -- & 218,569 \\
78,918 & -- & -- & -- & 78,918 \\
\hline $7,193,508$ & 656,841 & 8,078 & 51,911 & $7,910,338$ \\
\hline
\end{tabular}


Table 14--Net volume of sawtimber (Scribner rule) on timberland outside National Forests by ownership class, forest type, and stand-size class in New Mexico, 1987

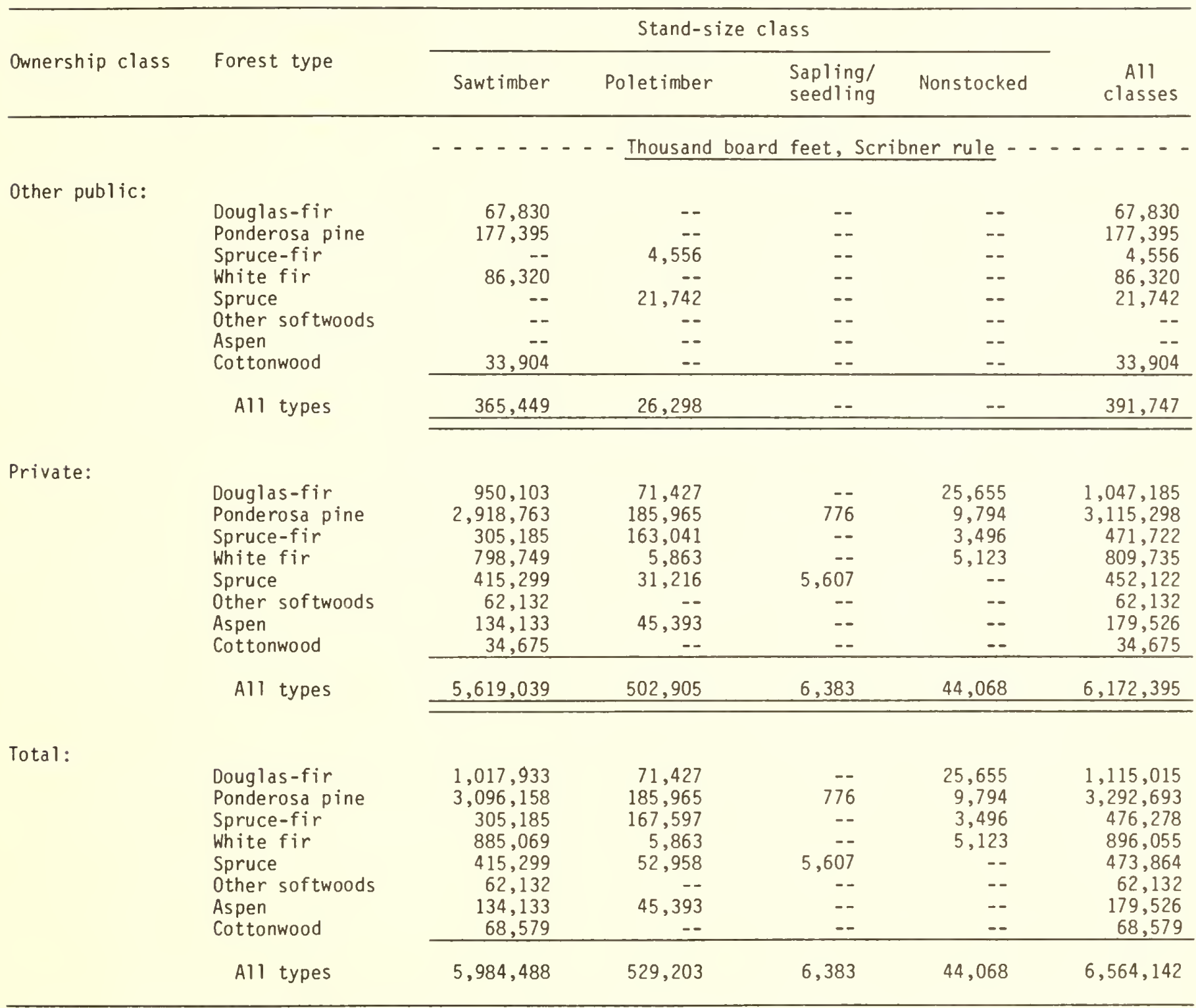


Table 15--Net volume of growing stock on timberland outside National Forests by species and ownership class in New Mexico, 1987

\begin{tabular}{|c|c|c|c|}
\hline \multirow{2}{*}{ Species } & \multicolumn{2}{|c|}{ Ownership class } & \multirow[b]{2}{*}{ Total } \\
\hline & $\begin{array}{l}\text { Other } \\
\text { public }\end{array}$ & Private & \\
\hline & --- & sand cubic & $---\cdot$ \\
\hline $\begin{array}{l}\text { Douglas-fir } \\
\text { Ponderosa pine } \\
\text { Whitebark pine } \\
\text { Limber pine } \\
\text { Subalpine fir } \\
\text { White fir } \\
\text { Engelmann spruce }\end{array}$ & $\begin{array}{r}31,303 \\
47,730 \\
-- \\
736 \\
389 \\
23,683 \\
10,624 \\
\end{array}$ & $\begin{array}{r}355,580 \\
886,627 \\
4,014 \\
40,875 \\
91,256 \\
188,323 \\
221,885 \\
\end{array}$ & $\begin{array}{r}386,883 \\
934,357 \\
4,014 \\
41,611 \\
91,645 \\
212,006 \\
232,509 \\
\end{array}$ \\
\hline Total softwoods & 114,465 & $1,788,560$ & $1,903,025$ \\
\hline $\begin{array}{l}\text { Aspen } \\
\text { Cottonwood }\end{array}$ & $\begin{array}{r}4,710 \\
10,987 \\
\end{array}$ & $\begin{array}{r}151,006 \\
11,736 \\
\end{array}$ & $\begin{array}{r}155,716 \\
22,723 \\
\end{array}$ \\
\hline Total hardwoods & 15,697 & 162,742 & 178,439 \\
\hline Alt species & 130,162 & $1,951,302$ & $2,081,464$ \\
\hline
\end{tabular}

Table 16--Net volume of sawtimber (International 1 -inch rule) on timberland outside National Forests by species and ownership class in New Mexico, 1987

\begin{tabular}{|c|c|c|c|}
\hline \multirow{2}{*}{ Species } & \multicolumn{2}{|c|}{ Ownership class } & \multirow[b]{2}{*}{ Total } \\
\hline & $\begin{array}{l}\text { Other } \\
\text { public }\end{array}$ & Private & \\
\hline & usand boa & , Interna & $\frac{1}{4}$-inch rule \\
\hline $\begin{array}{l}\text { Douglas-fir } \\
\text { Ponderosa pine } \\
\text { Whitebark pine } \\
\text { Limber pine } \\
\text { Subalpine fir } \\
\text { White fir } \\
\text { Engelmann spruce }\end{array}$ & $\begin{array}{r}107,484 \\
208,881 \\
-- \\
2,730 \\
-- \\
87,692 \\
27,076 \\
\end{array}$ & $\begin{array}{r}1,338,621 \\
3,763,579 \\
20,794 \\
138,364 \\
241,827 \\
671,487 \\
816,449 \\
\end{array}$ & $\begin{array}{r}1,446,105 \\
3,972,460 \\
20,794 \\
141,094 \\
241,827 \\
759,179 \\
843,525 \\
\end{array}$ \\
\hline Total softwoods & 433,863 & $6,991,121$ & $7,424,984$ \\
\hline $\begin{array}{l}\text { Aspen } \\
\text { Cottonwood }\end{array}$ & 39,373 & $\begin{array}{r}406,436 \\
39,545 \\
\end{array}$ & $\begin{array}{r}406,436 \\
78,918 \\
\end{array}$ \\
\hline Total hardwoods & 39,373 & 445,981 & 485,354 \\
\hline All speries & 473,236 & $7,437,102$ & $7,910,338$ \\
\hline
\end{tabular}


Table 17--Net volume of sawtimber (Scribner rule) on timberland outside National Forests by species and ownership class in New Mexico, 1987

\begin{tabular}{|c|c|c|c|}
\hline \multirow[b]{2}{*}{ Species } & \multicolumn{2}{|c|}{ Ownership class } & \multirow[b]{2}{*}{ Total } \\
\hline & $\begin{array}{l}\text { Other } \\
\text { public }\end{array}$ & Private & \\
\hline & - - Thou & oard feet, & er rule - - \\
\hline $\begin{array}{l}\text { Douglas-fir } \\
\text { Ponderosa pine } \\
\text { Whitebark pine } \\
\text { Limber pine } \\
\text { Subalpine fir } \\
\text { White fir } \\
\text { Engelmann spruce }\end{array}$ & $\begin{array}{r}84,658 \\
175,352 \\
-- \\
2,402 \\
-- \\
73,891 \\
21,540 \\
\end{array}$ & $\begin{array}{r}1,072,622 \\
3,185,918 \\
18,270 \\
116,606 \\
191,515 \\
572,582 \\
653,913 \\
\end{array}$ & $\begin{array}{r}1,157,280 \\
3,361,270 \\
18,270 \\
119,008 \\
191,515 \\
646,473 \\
675,453 \\
\end{array}$ \\
\hline Total softwoods & 357,843 & $5,811,426$ & $6,169,269$ \\
\hline $\begin{array}{l}\text { Aspen } \\
\text { Cottonwood }\end{array}$ & 33,904 & $\begin{array}{r}326,294 \\
34,675 \\
\end{array}$ & $\begin{array}{r}326,294 \\
68,579 \\
\end{array}$ \\
\hline Total hardwoods & 33,904 & 360,969 & 394,873 \\
\hline All species & 391,747 & $6,172,395$ & $6,564,142$ \\
\hline
\end{tabular}




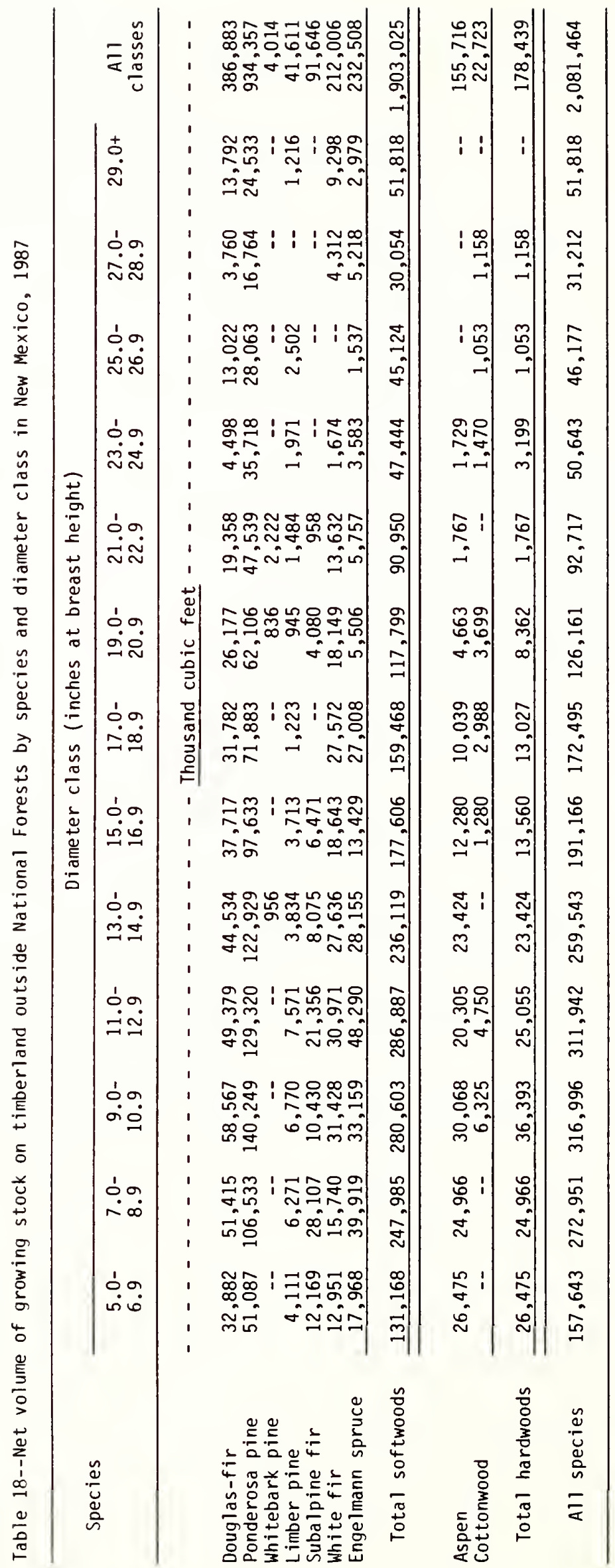




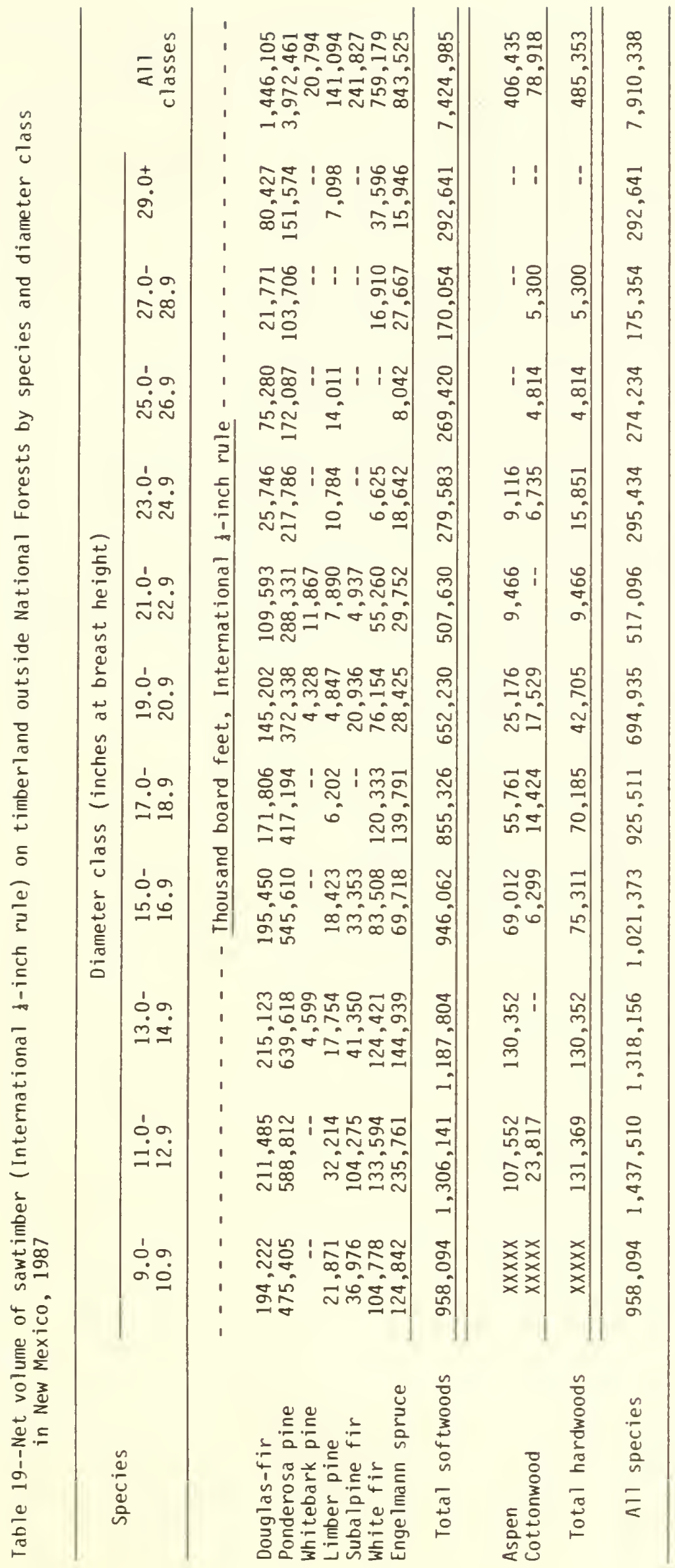




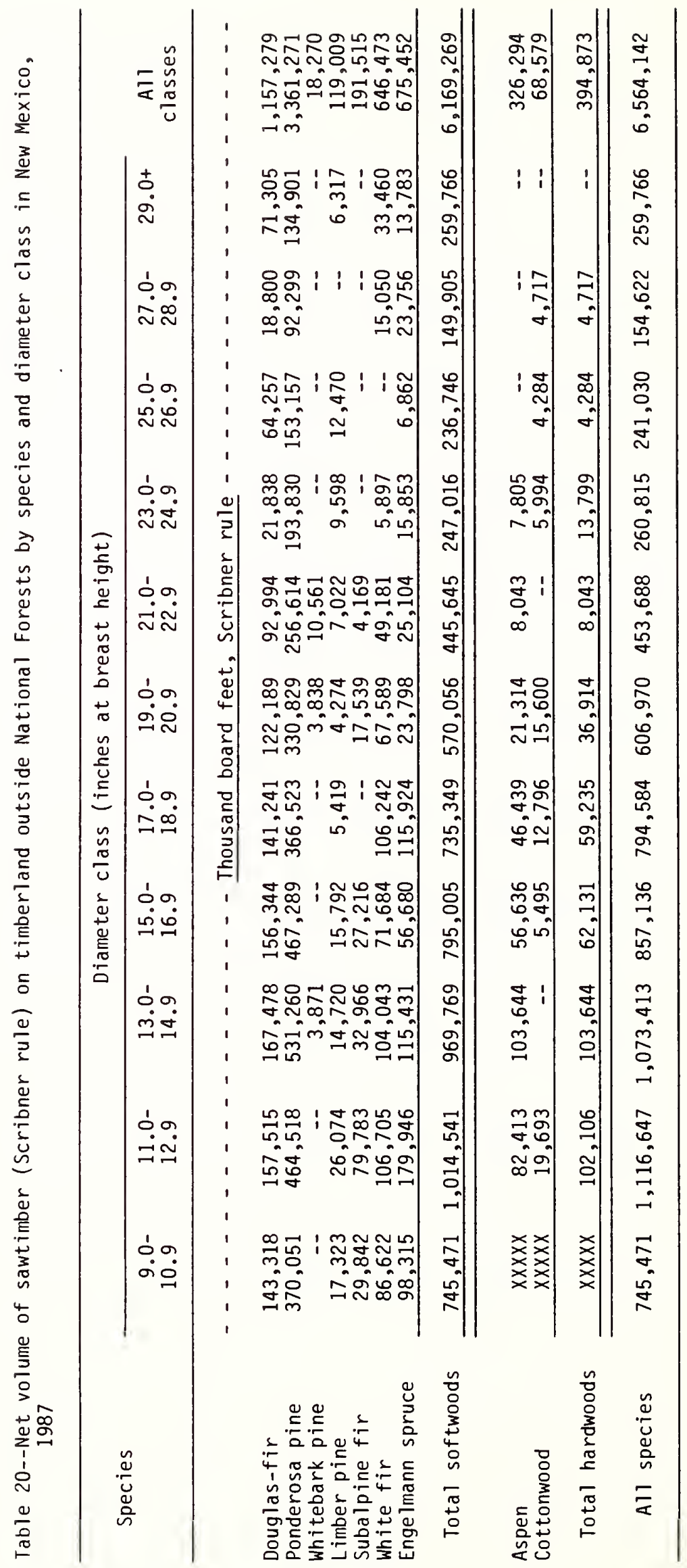


Table 21--Net volume of timber on timberland outside National

Forests by class of timber, and softwoods and hardwoods in New Mexico, 1987

\begin{tabular}{|c|c|c|c|}
\hline Class of timber & Softwoods & Hardwoods & Total \\
\hline & \multicolumn{3}{|c|}{ - - - Thousand cubic feet $-\ldots$} \\
\hline $\begin{array}{l}\text { Sawtimber trees: } \\
\text { Sawlog portion } \\
\text { Upper-stem portion }\end{array}$ & $\begin{array}{r}1,432,377 \\
91,495 \\
\end{array}$ & $\begin{array}{r}84,027 \\
6,578 \\
\end{array}$ & $\begin{array}{r}1,516,404 \\
98,073 \\
\end{array}$ \\
\hline Total & $1,523,872$ & 90,605 & $1,614,477$ \\
\hline Poletimber trees & 379,153 & 87,834 & 466,987 \\
\hline All growing-stock trees & $1,903,025$ & 178,439 & $2,081,464$ \\
\hline $\begin{array}{l}\text { Rough cull trees } \\
\text { Rotten cull trees } \\
\text { Salvable dead trees }\end{array}$ & $\begin{array}{r}6,528 \\
6,141 \\
101,336 \\
\end{array}$ & $\begin{array}{r}1,393 \\
5,813 \\
29,914 \\
\end{array}$ & $\begin{array}{r}7,921 \\
11,954 \\
131,250 \\
\end{array}$ \\
\hline All timber & $2,017,030$ & 215,559 & $2,232,589$ \\
\hline
\end{tabular}



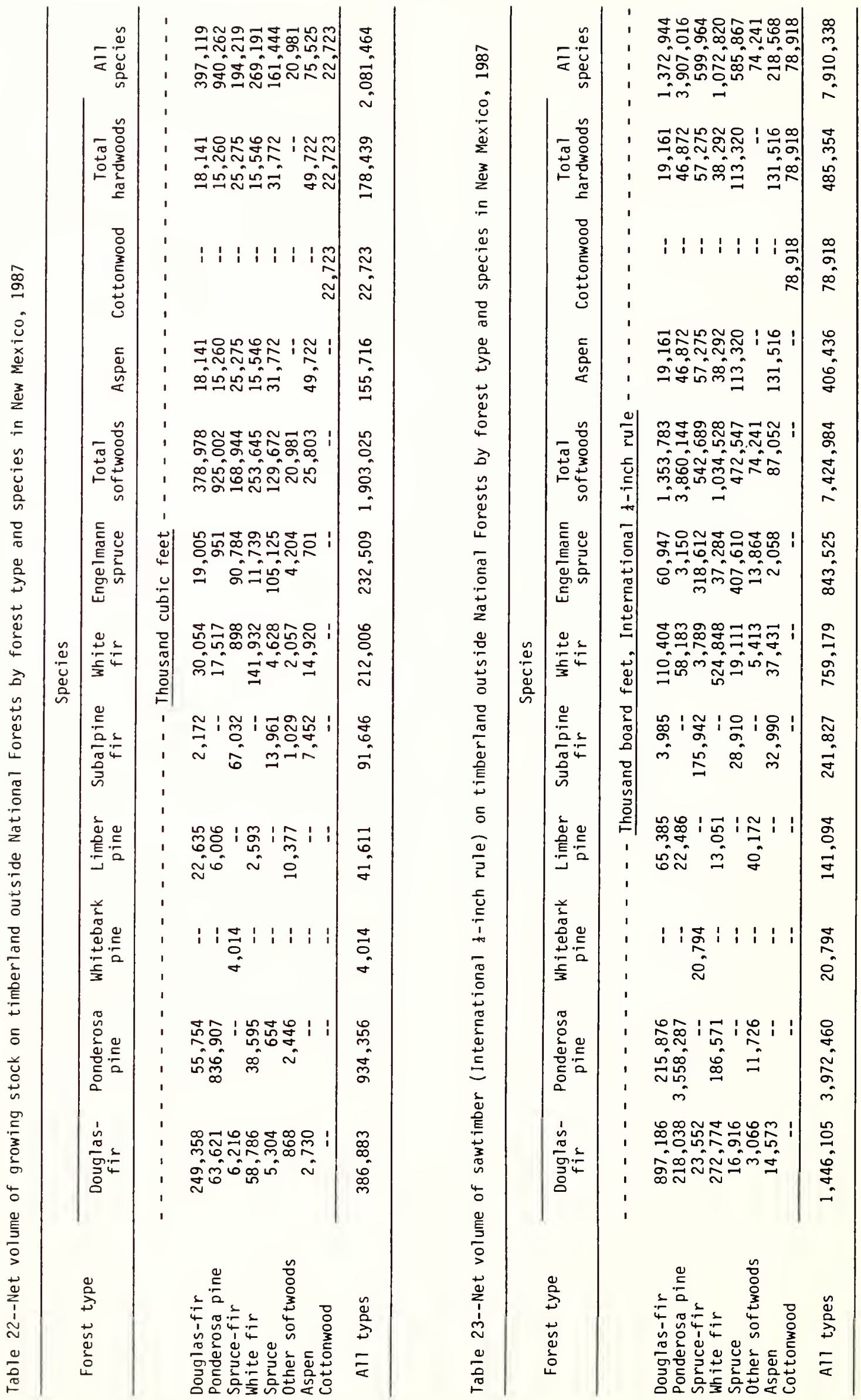


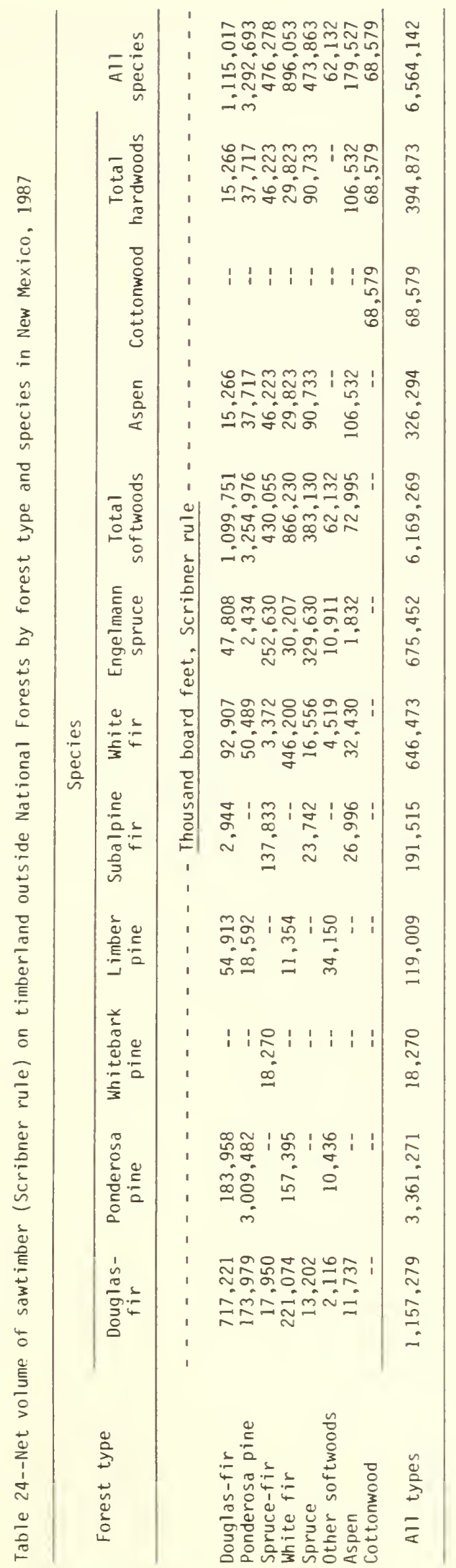


Table 25--Net annual growth of growing stock on timberland outside National Forests by species and ownership class in New Mexico, 1986

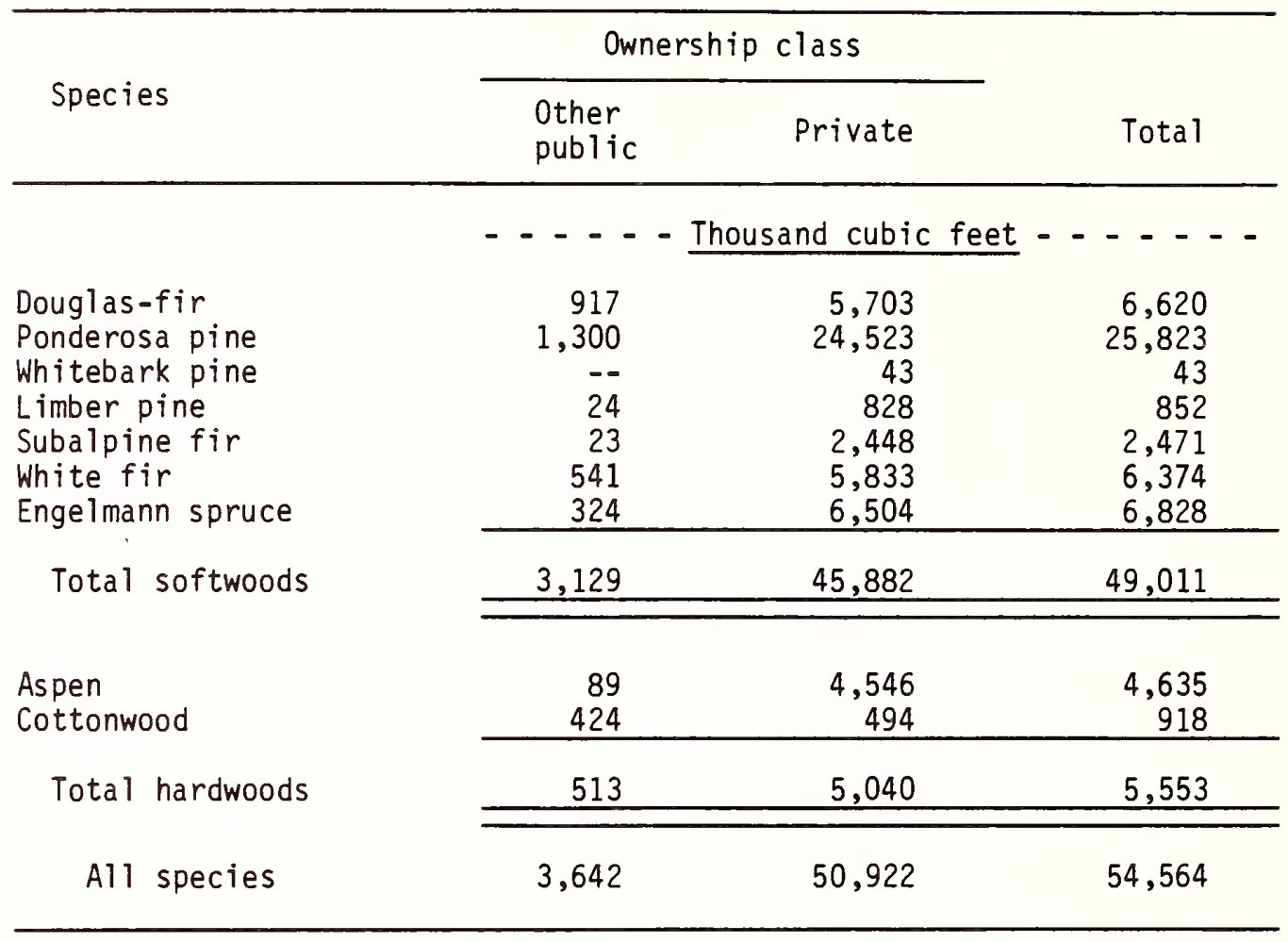

Table 26--Net annual growth of sawtimber (International $\frac{1}{4}$-inch rule) on timberland outside National Forests by species and ownership class in New Mexico, 1986

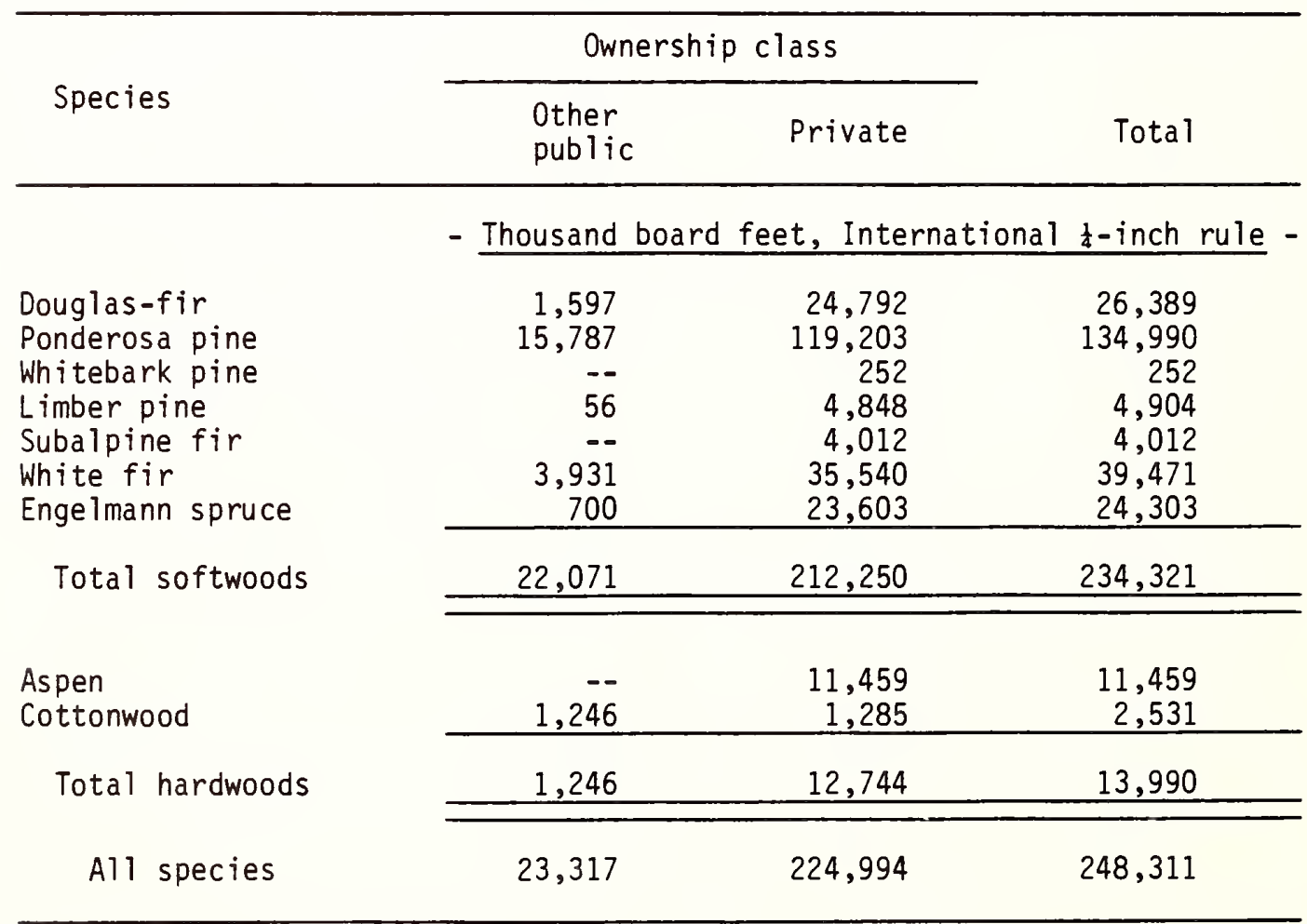


Table 27--Net annual growth of sawtimber (Scribner rule) on timberland outside National Forests by species and ownership class in New Mexico, 1986

\begin{tabular}{|c|c|c|c|}
\hline \multirow{2}{*}{ Species } & \multicolumn{2}{|c|}{ Ownership class } & \multirow[b]{2}{*}{ Total } \\
\hline & $\begin{array}{l}\text { Other } \\
\text { public }\end{array}$ & Private & \\
\hline & - - Thousa & d feet, s & rule - \\
\hline $\begin{array}{l}\text { Douglas-fir } \\
\text { Ponderosa pine } \\
\text { Whitebark pine } \\
\text { Limber pine } \\
\text { Subalpine fir } \\
\text { White fir } \\
\text { Engelmann spruce }\end{array}$ & $\begin{array}{r}1,370 \\
11,083 \\
-- \\
50 \\
-- \\
3,505 \\
581 \\
\end{array}$ & $\begin{array}{r}20,336 \\
97,832 \\
226 \\
3,711 \\
3,491 \\
31,603 \\
20,157 \\
\end{array}$ & $\begin{array}{r}21,706 \\
108,915 \\
226 \\
3,761 \\
3,491 \\
35,108 \\
20,738 \\
\end{array}$ \\
\hline Total softwoods & 16,589 & 177,356 & 193,945 \\
\hline $\begin{array}{l}\text { Aspen } \\
\text { Cottonwood }\end{array}$ & 1,094 & $\begin{array}{l}9,102 \\
1,168 \\
\end{array}$ & $\begin{array}{l}9,102 \\
2,262 \\
\end{array}$ \\
\hline Total hardwoods & 1,094 & 10,270 & 11,364 \\
\hline All species & 17,683 & 187,626 & 205,309 \\
\hline
\end{tabular}




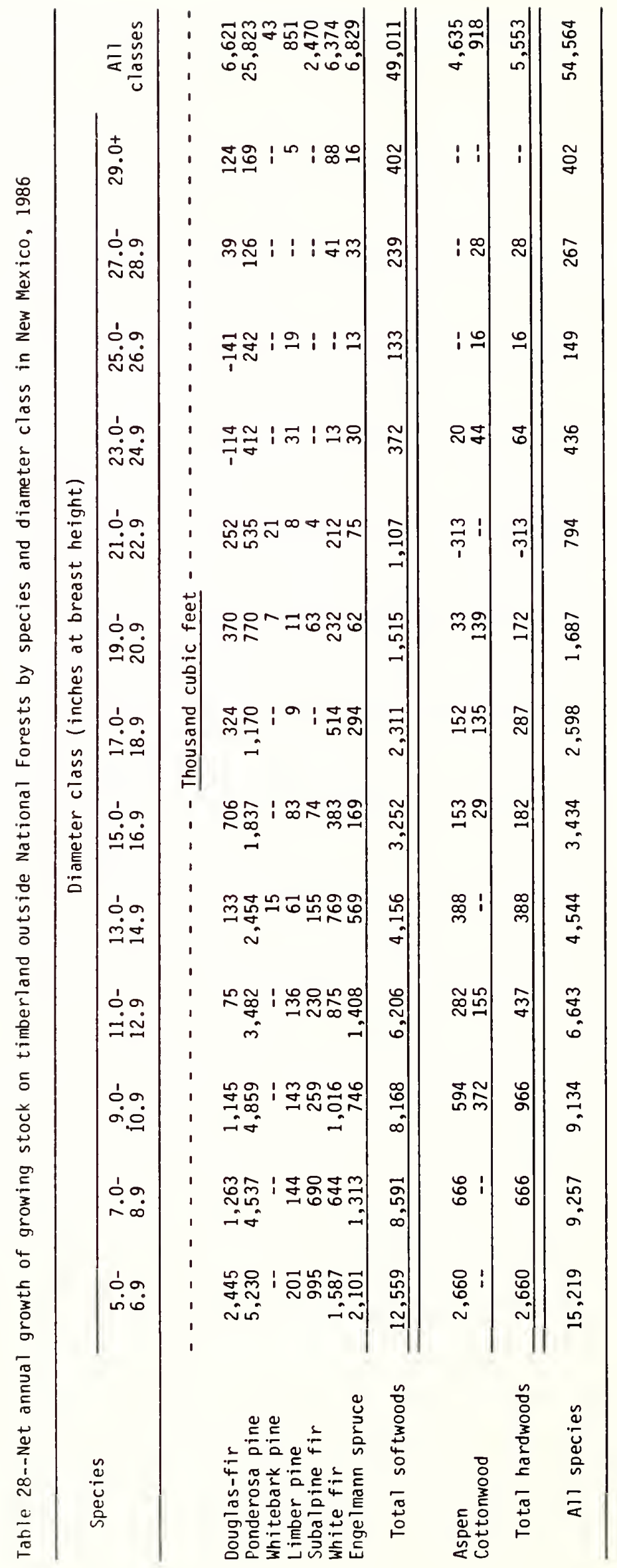




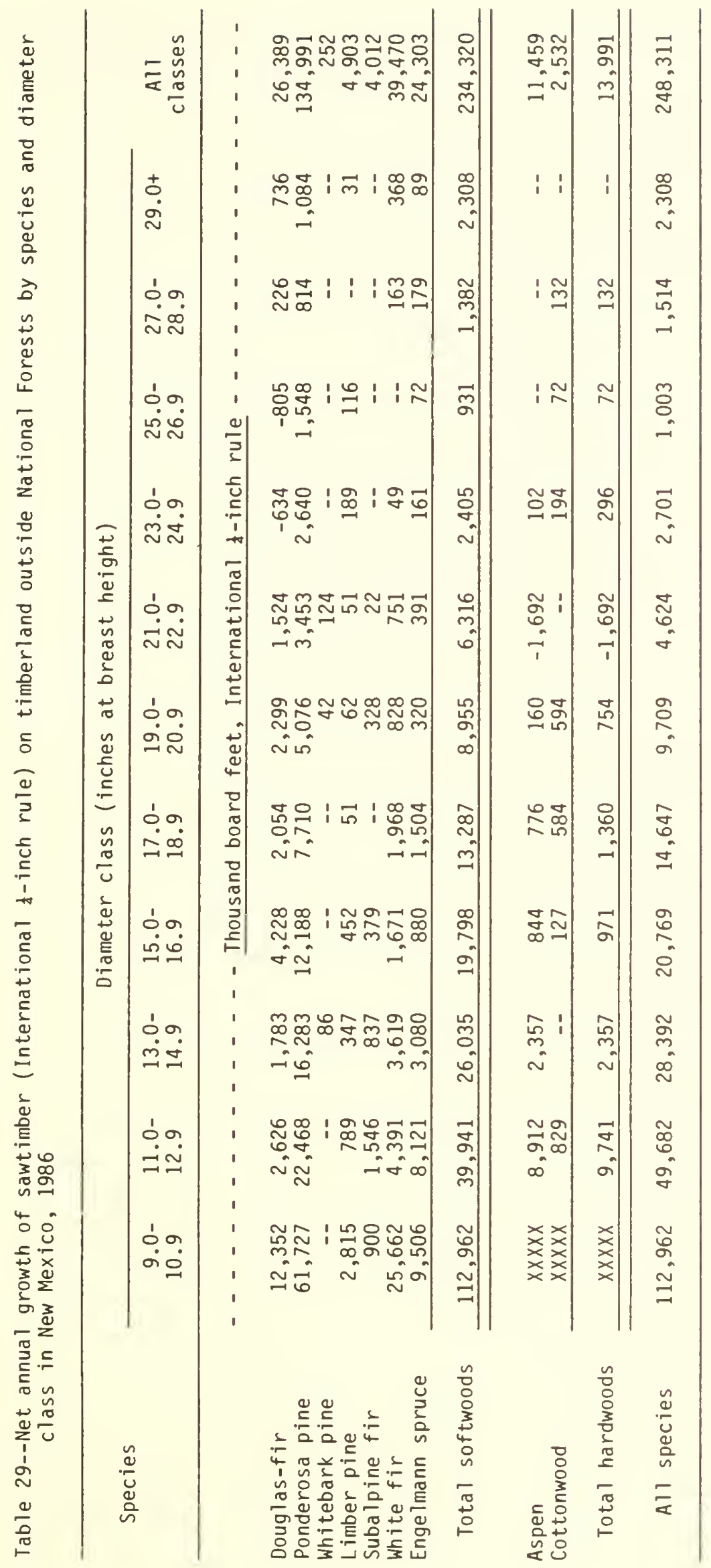




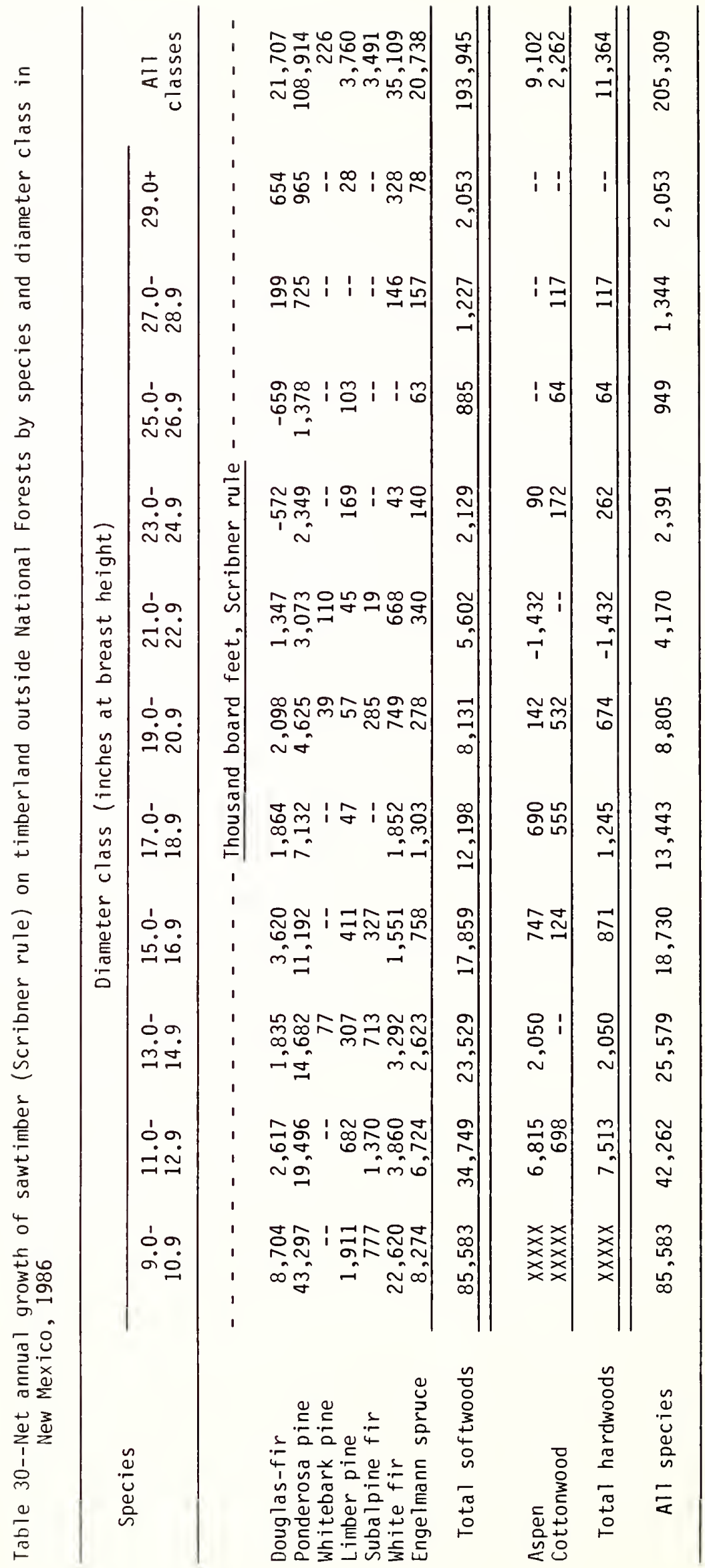


Table 31--Annual mortality of growing stock on timberland outside National Forests by species and ownership class in New Mexico, 1986

\begin{tabular}{|c|c|c|c|}
\hline \multirow[b]{2}{*}{ Species } & \multicolumn{2}{|c|}{ Ownership class } & \multirow[b]{2}{*}{ Total } \\
\hline & $\begin{array}{l}\text { Other } \\
\text { public }\end{array}$ & Private & \\
\hline & $--\cdot-$ & nd cubic f & -- \\
\hline $\begin{array}{l}\text { Douglas-fir } \\
\text { Ponderosa pine }\end{array}$ & 266 & $\begin{array}{r}4,585 \\
355\end{array}$ & $\begin{array}{r}4,851 \\
355\end{array}$ \\
\hline Whitebark pine & -- & -- & - \\
\hline Limber pine & -- & -- & - \\
\hline Subalpine fir & -- & 575 & 575 \\
\hline White fir & -- & -- & -- \\
\hline Engelmann spruce & -- & -- & -- \\
\hline Total softwoods & 266 & 5,515 & 5,781 \\
\hline Aspen & -- & 440 & 440 \\
\hline Cottonwood & -- & -- & - \\
\hline Total hardwoods & -- & 440 & 440 \\
\hline All species & 266 & 5,955 & 6,221 \\
\hline
\end{tabular}

Table 32--Annual mortality of sawtimber (International $\frac{1}{4}$-inch rule) on timberland outside National Forests by species and ownership class in New Mexico, 1986

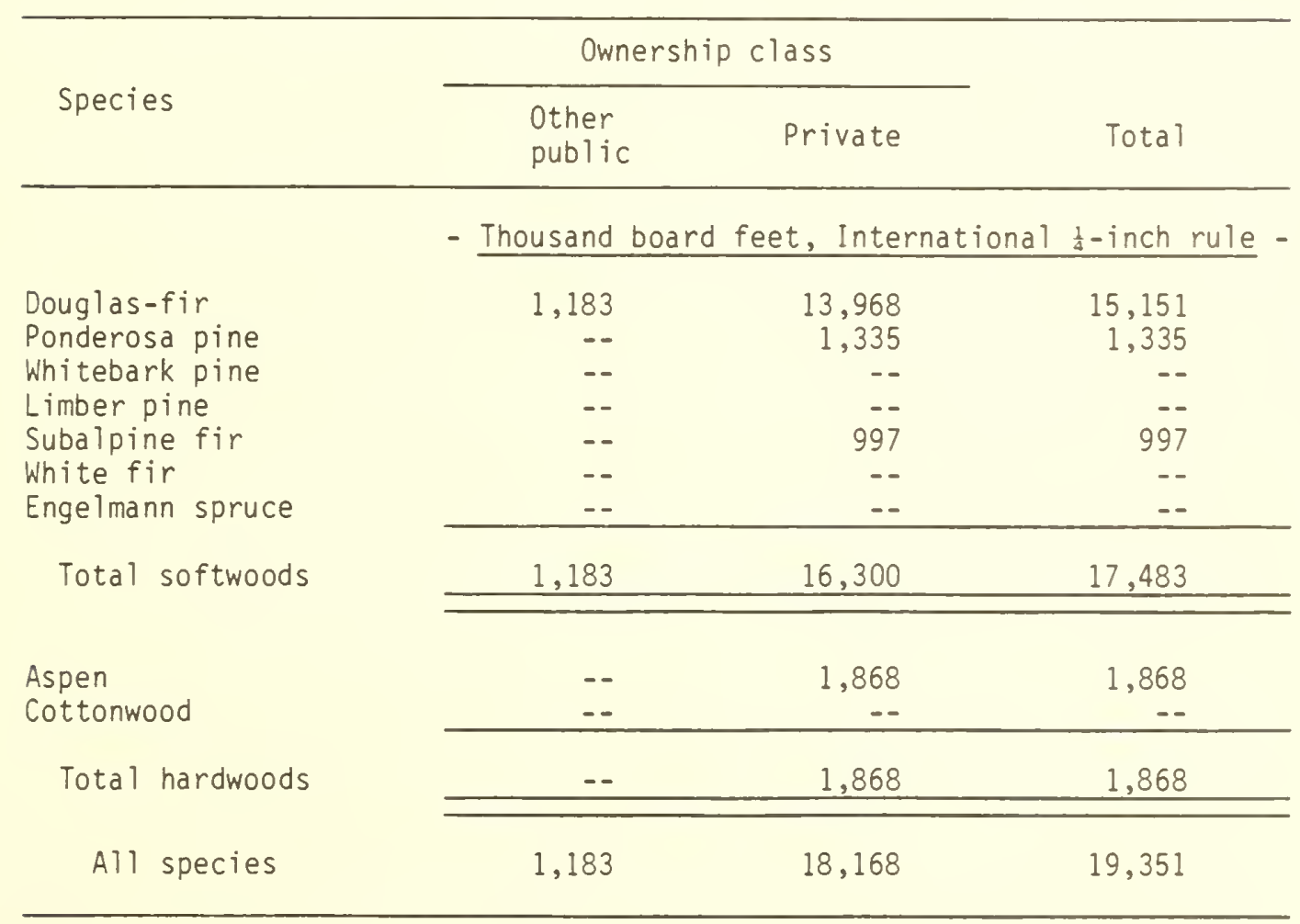


Table 33--Annual mortality of sawtimber (Scribner rule) on timberland outside National Forests by species and ownership class in New Mexico, 1986

\begin{tabular}{|c|c|c|c|}
\hline \multirow[b]{2}{*}{ Species } & \multicolumn{2}{|c|}{ Ownership class } & \multirow[b]{2}{*}{ Total } \\
\hline & $\begin{array}{l}\text { Other } \\
\text { public }\end{array}$ & Private & \\
\hline & - - Thousan & 1 feet, Sc & ule - - \\
\hline $\begin{array}{l}\text { Douglas-fir } \\
\text { Ponderosa pine }\end{array}$ & $\begin{array}{r}920 \\
--\end{array}$ & $\begin{array}{r}10,891 \\
1,082\end{array}$ & $\begin{array}{r}11,811 \\
1,082\end{array}$ \\
\hline Whitebark pine & -- & -- & -- \\
\hline Limber pine & -- & -- & -- \\
\hline Subalpine fir & -- & 743 & 743 \\
\hline White fir & -- & -- & -- \\
\hline Engelmann spruce & - & -- & -- \\
\hline Total softwoods & 920 & 12,716 & 13,636 \\
\hline $\begin{array}{l}\text { Aspen } \\
\text { Cottonwood }\end{array}$ & $\begin{array}{l}-- \\
--\end{array}$ & $\begin{array}{r}1,588 \\
--\end{array}$ & $\begin{array}{r}1,588 \\
--\end{array}$ \\
\hline Total hardwoods & - & 1,588 & 1,588 \\
\hline All species & 920 & 14,304 & 15,224 \\
\hline
\end{tabular}




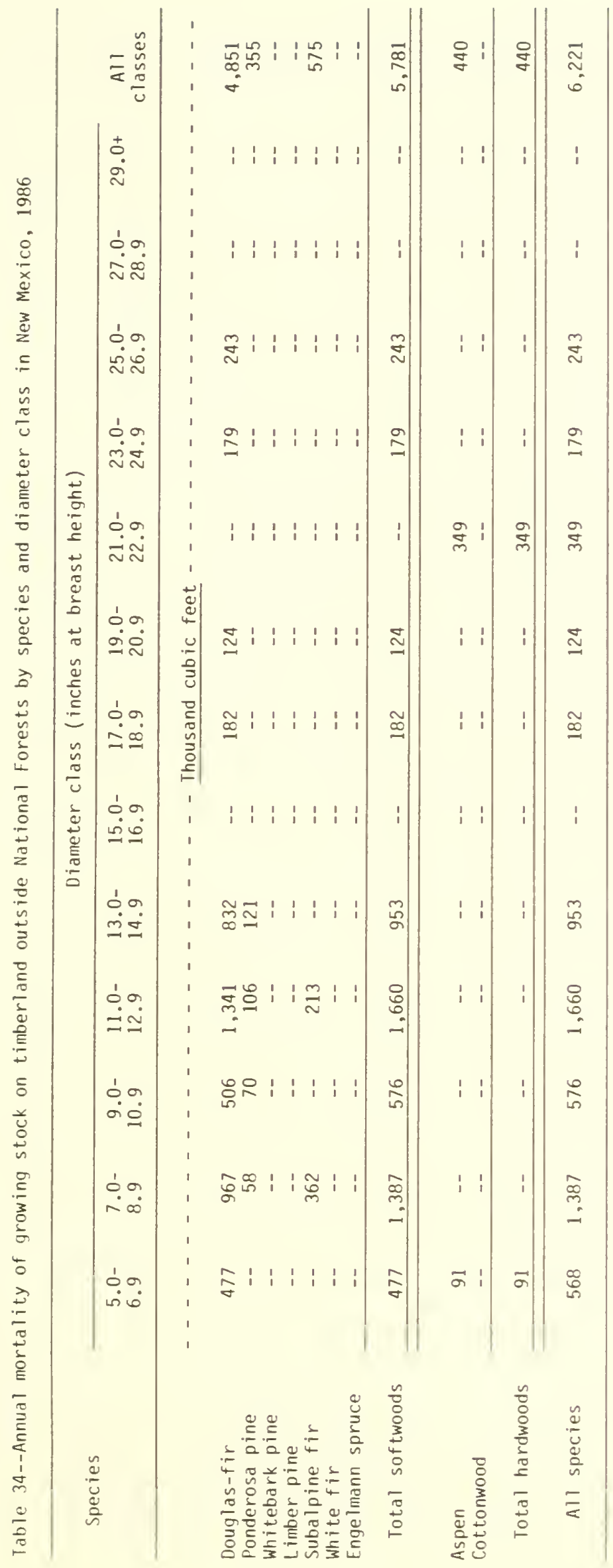




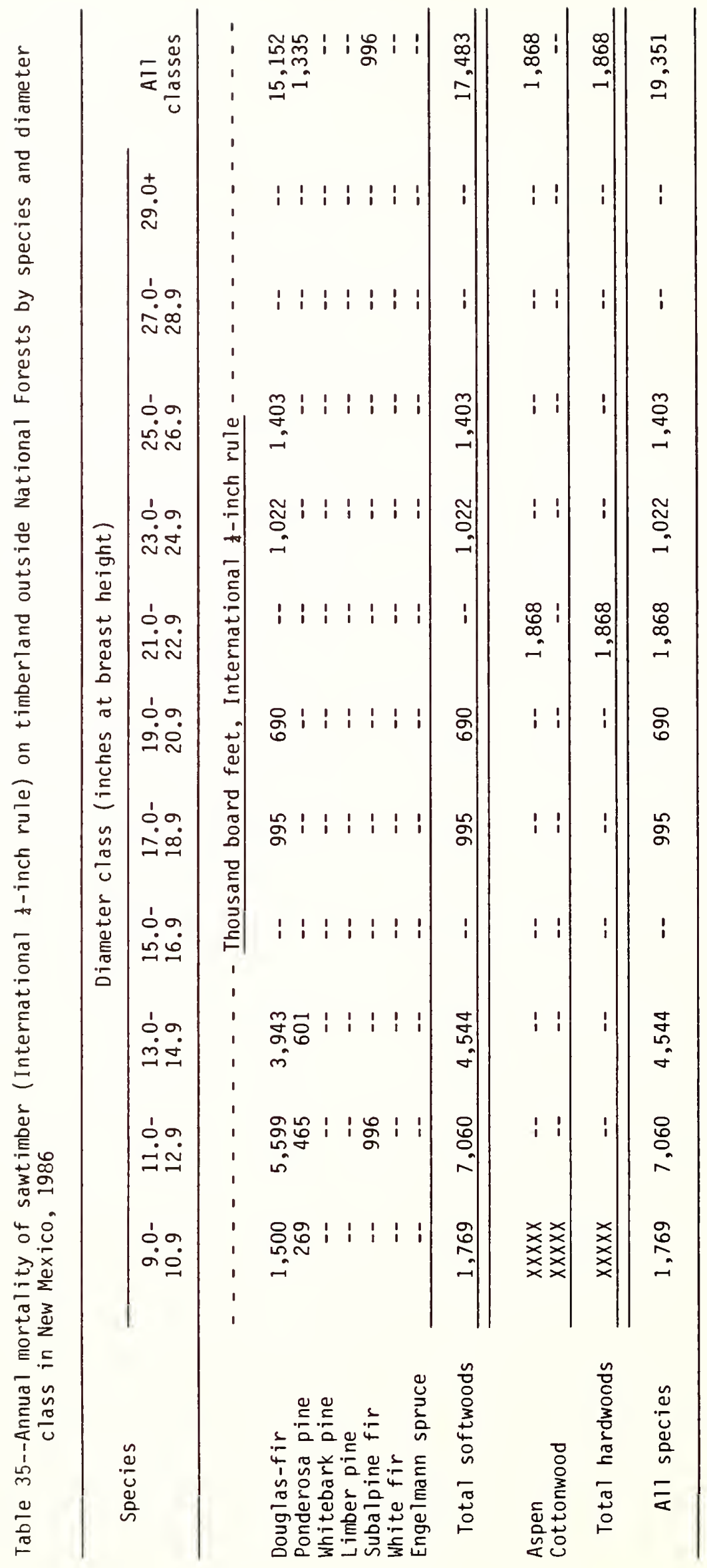




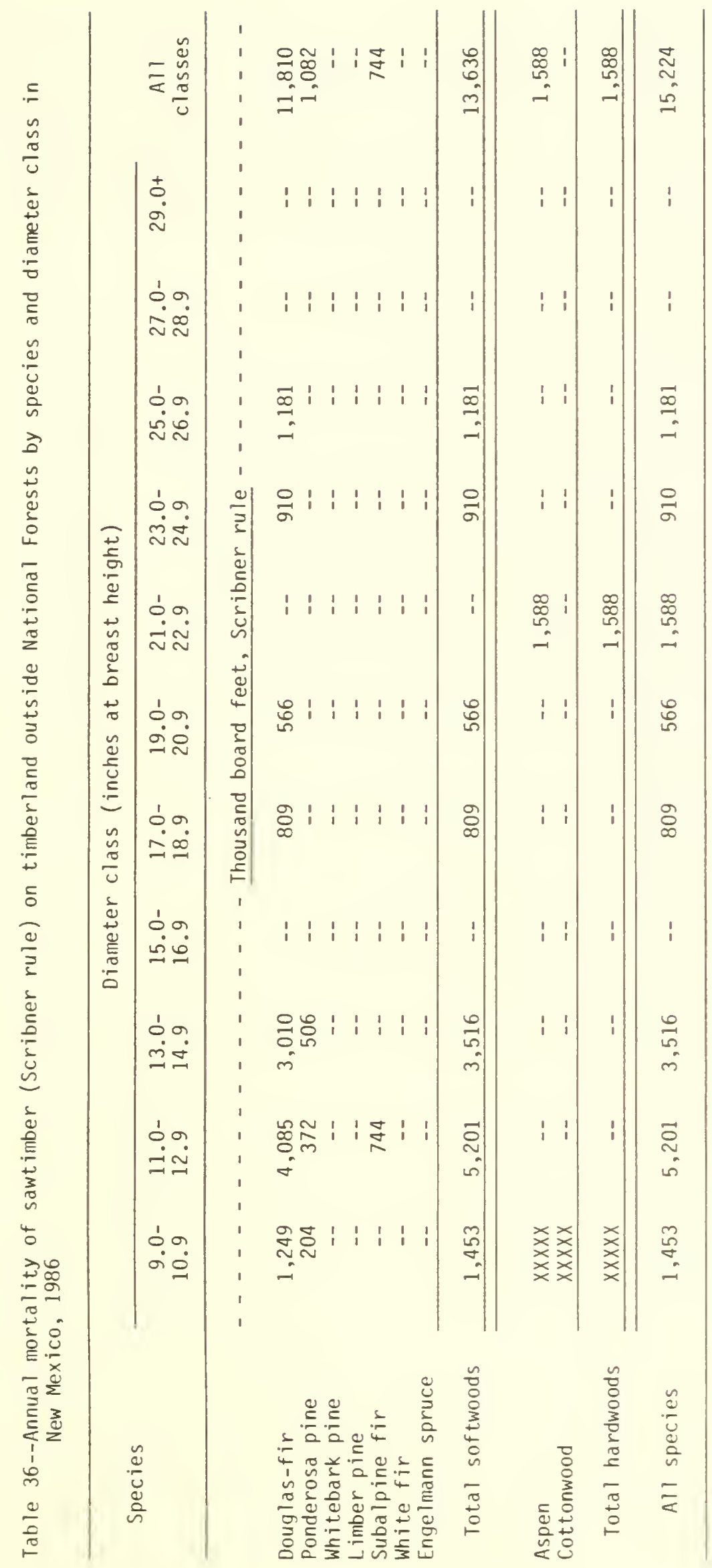


Table 37--Annual mortality of growing stock on timberland outside National Forests by species and cause of death in New Mexico, 1986

Species

Cause of death

Insects Disease Fire Animal Weather Suppression Logging Unknown ${ }^{1}$ Total

Douglas-fir

Ponderosa pine

Whitebark pine

Limber pine

Subalpine fir

White fir

Engelmann spruce

Total softwoods

Aspen

Cottonwood

Total hardwoods

All species

\begin{tabular}{rr}
3,951 & 358 \\
-- & 6 \\
-- & -- \\
-- & -- \\
-- & 255 \\
-- & -- \\
-- & -- \\
\hline
\end{tabular}

$\begin{array}{ll}-- & - \\ -- & - \\ -- & - \\ -- & - \\ -- & - \\ -- & -\end{array}$

$--\quad-$

\begin{tabular}{ll}
-- & -- \\
-- & -- \\
-- & -- \\
-- & -- \\
-- & -- \\
-- & -- \\
-- & -- \\
\hline
\end{tabular}

\begin{tabular}{ll}
-- & -- \\
-- & -- \\
-- & -- \\
-- & -- \\
-- & -- \\
-- & -- \\
-- & -- \\
\hline
\end{tabular}

--
--
--
--
--
--

542

349

--

320

$--$

$\begin{array}{llllll}3,951 & 619 & - & - & - & -\end{array}$

$--$

$-\quad 1,211$

5,781

\begin{tabular}{rrrrrrrrr}
-- & -- & -- & -- & -- & -- & -- & 440 & 440 \\
-- & -- & -- & -- & -- & -- & -- & -- & -- \\
\hline-- & -- & -- & -- & -- & -- & -- & 440 & 440 \\
\hline 3,951 & 619 & -- & -- & -- & -- & -- & 1,651 & 6,221
\end{tabular}

${ }^{1}$ Because many destructive agents often attack trees in concert or in succession, it is often difficult to identify the actual causal agent. When the primary cause of death cannot be precisely determined, it is listed as unknown.

Table 38--Annual mortality of sawtimber (International 1 -inch rule) on timberland outside National Forests by species and cause of death in New Mexico, 1986

Species

Cause of death

Insects Disease Fire Animal Weather Suppression Logging Unknown Total

- - - - - - - Thousand board feet, International $\frac{1}{4}$-inch rule - - - - - - -

Douglas-fir Ponderosa pine Whitebark pine Limber pine Subalpine fir White fir

Engelmann spruce

Total softwoods

\section{Aspen}

Cottonwood

Total hardwoods

A11 species

$\begin{array}{rrrr}11,858 & 547 & -- \\ -- & -- & -- & -- \\ -- & -- & - & - \\ -- & -- & - \\ -- & -- & -- \\ -- & -- & -- \\ -- & -- & -\end{array}$

$\begin{array}{ll}-- & - \\ -- & - \\ -- & - \\ -- & - \\ -- & - \\ -- & - \\ -- & -\end{array}$

--
--
--
--
--
--

$--$

\begin{tabular}{lll}
11,858 & 547 & -- \\
\hline
\end{tabular}

$-$

\begin{tabular}{rrrrrrrrr}
-- & -- & -- & -- & -- & -- & -- & 1,868 & 1,868 \\
-- & -- & -- & -- & -- & -- & -- & -- & $-1,868$ \\
\hline-- & -- & -- & -- & -- & - & - & 1,868 \\
\hline 11,858 & 547 & -- & -- & -- & -- & -- & 6,946 & 19,351
\end{tabular}




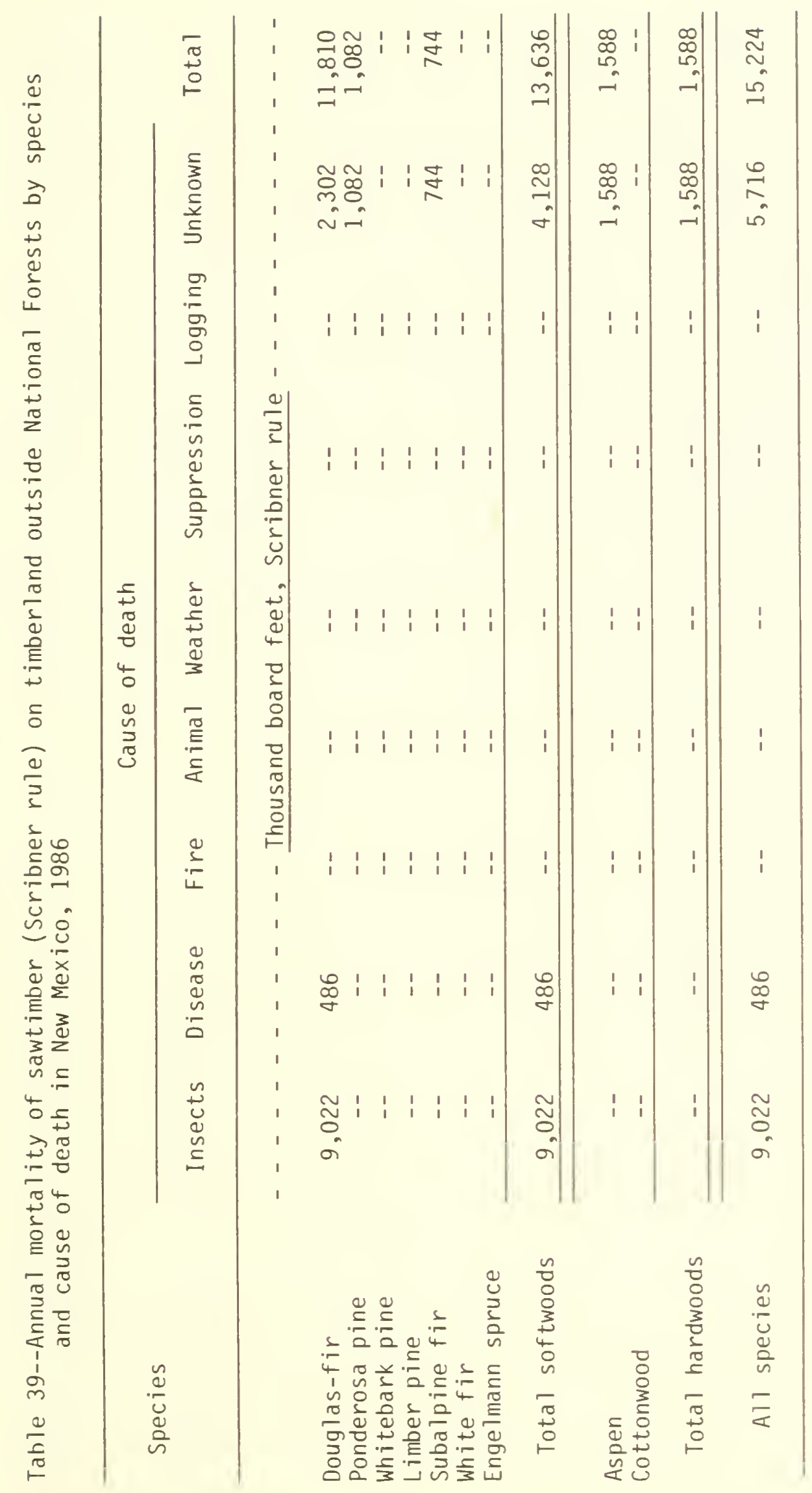


Table 40--Area of woodland outside National Forests by forest type and ownership class in New Mexico, 1987

\begin{tabular}{|c|c|c|c|}
\hline \multirow{2}{*}{ Forest type } & \multicolumn{2}{|c|}{ Ownership class } & \multirow[b]{2}{*}{ Total } \\
\hline & $\begin{array}{l}\text { Other } \\
\text { public }\end{array}$ & Private & \\
\hline & $---\cdot-$ & - Acres - & $---\cdot-$ \\
\hline $\begin{array}{l}\text { Pinyon-juniper } \\
\text { Juniper }\end{array}$ & $\begin{array}{r}1,526,290 \\
186,354 \\
\end{array}$ & $\begin{array}{r}3,512,189 \\
335,166 \\
\end{array}$ & $\begin{array}{r}5,038,479 \\
521,520 \\
\end{array}$ \\
\hline Total woodland softwoods & $1,712,644$ & $3,847,355$ & $5,559,999$ \\
\hline Oak & 23,541 & 157,911 & 181,452 \\
\hline Total woodland hardwoods & 23,541 & 157,911 & 181,452 \\
\hline All types & $1,736,185$ & $4,005,266$ & $5,741,451$ \\
\hline
\end{tabular}

Table 41--Area of woodland outside National Forests by ownership class, forest type, and productivity class in New Mexico, 1987

\begin{tabular}{|c|c|c|c|c|}
\hline \multirow{2}{*}{$\begin{array}{l}\text { Ownership } \\
\text { class }\end{array}$} & \multirow{2}{*}{ Forest type } & \multicolumn{2}{|c|}{ Productivity class } & \multirow[b]{2}{*}{$\begin{array}{c}\text { All } \\
\text { classes }\end{array}$} \\
\hline & & High & Low & \\
\hline & & $--\cdot--$ & - Acres - - & $-\cdots$ \\
\hline \multirow[t]{2}{*}{ Other public: } & $\begin{array}{l}\text { Pinyon-juniper } \\
\text { Juniper } \\
\text { Oak }\end{array}$ & $\begin{array}{r}1,159,473 \\
155,601 \\
16,779 \\
\end{array}$ & $\begin{array}{r}366,817 \\
30,753 \\
6,762 \\
\end{array}$ & $\begin{array}{r}1,526,290 \\
186,354 \\
23,541 \\
\end{array}$ \\
\hline & Total & $1,331,853$ & 404,332 & $1,736,185$ \\
\hline \multirow[t]{2}{*}{ Private: } & $\begin{array}{l}\text { Pinyon-juniper } \\
\text { Juniper } \\
\text { Oak }\end{array}$ & $\begin{array}{r}2,860,291 \\
246,570 \\
145,841 \\
\end{array}$ & $\begin{array}{r}651,898 \\
88,596 \\
12,070 \\
\end{array}$ & $\begin{array}{r}3,512,189 \\
335,166 \\
157,911 \\
\end{array}$ \\
\hline & Total & $3,252,702$ & 752,564 & $4,005,266$ \\
\hline \multirow[t]{2}{*}{ Total: } & $\begin{array}{l}\text { Pinyon-juniper } \\
\text { Juniper } \\
\text { Oak }\end{array}$ & $\begin{array}{r}4,019,764 \\
402,171 \\
162,620 \\
\end{array}$ & $\begin{array}{r}1,018,715 \\
119,349 \\
18,832 \\
\end{array}$ & $\begin{array}{r}5,038,479 \\
521,520 \\
181,452 \\
\end{array}$ \\
\hline & Total & $4,584,555$ & $1,156,896$ & $5,741,451$ \\
\hline
\end{tabular}




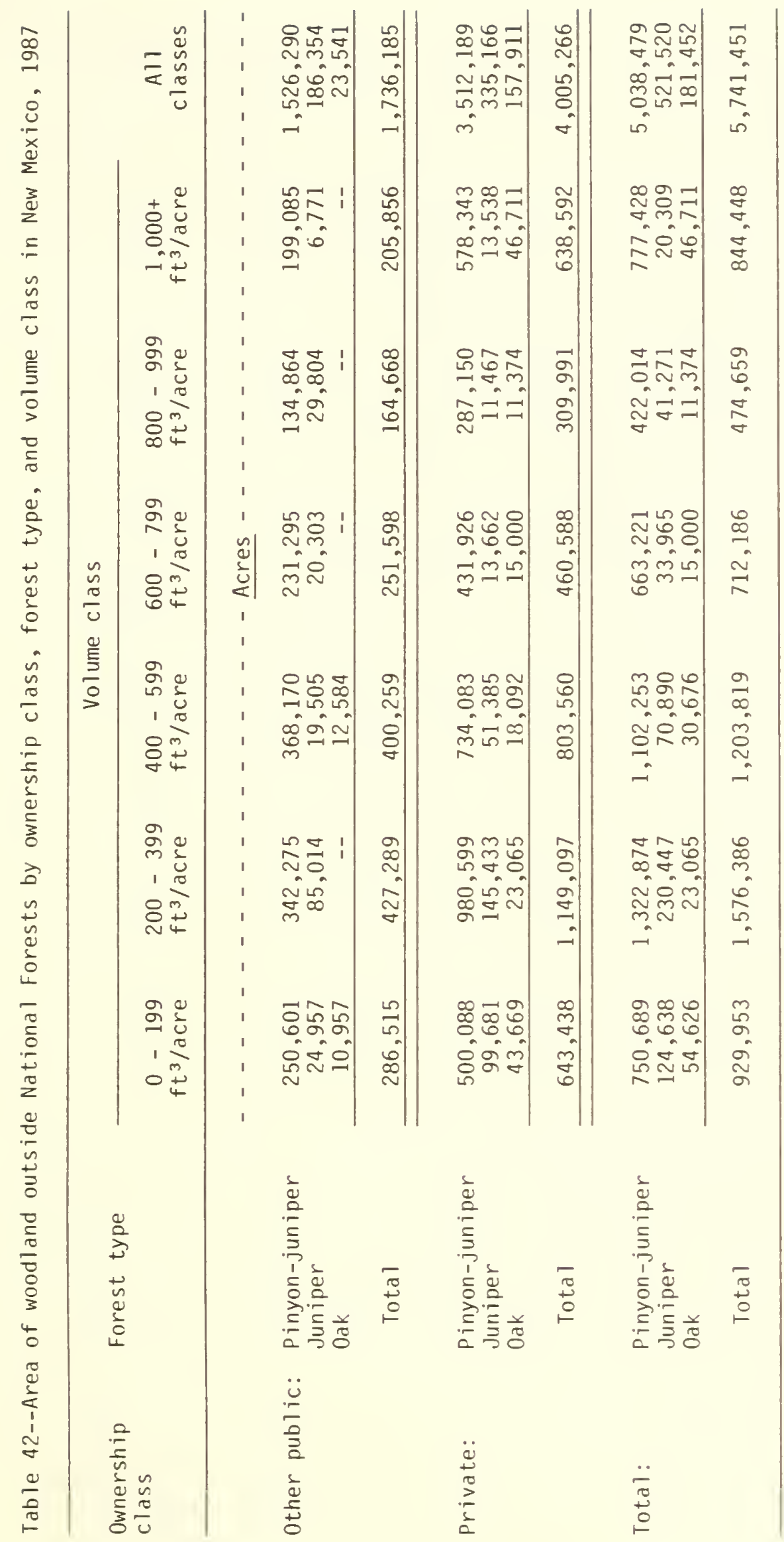




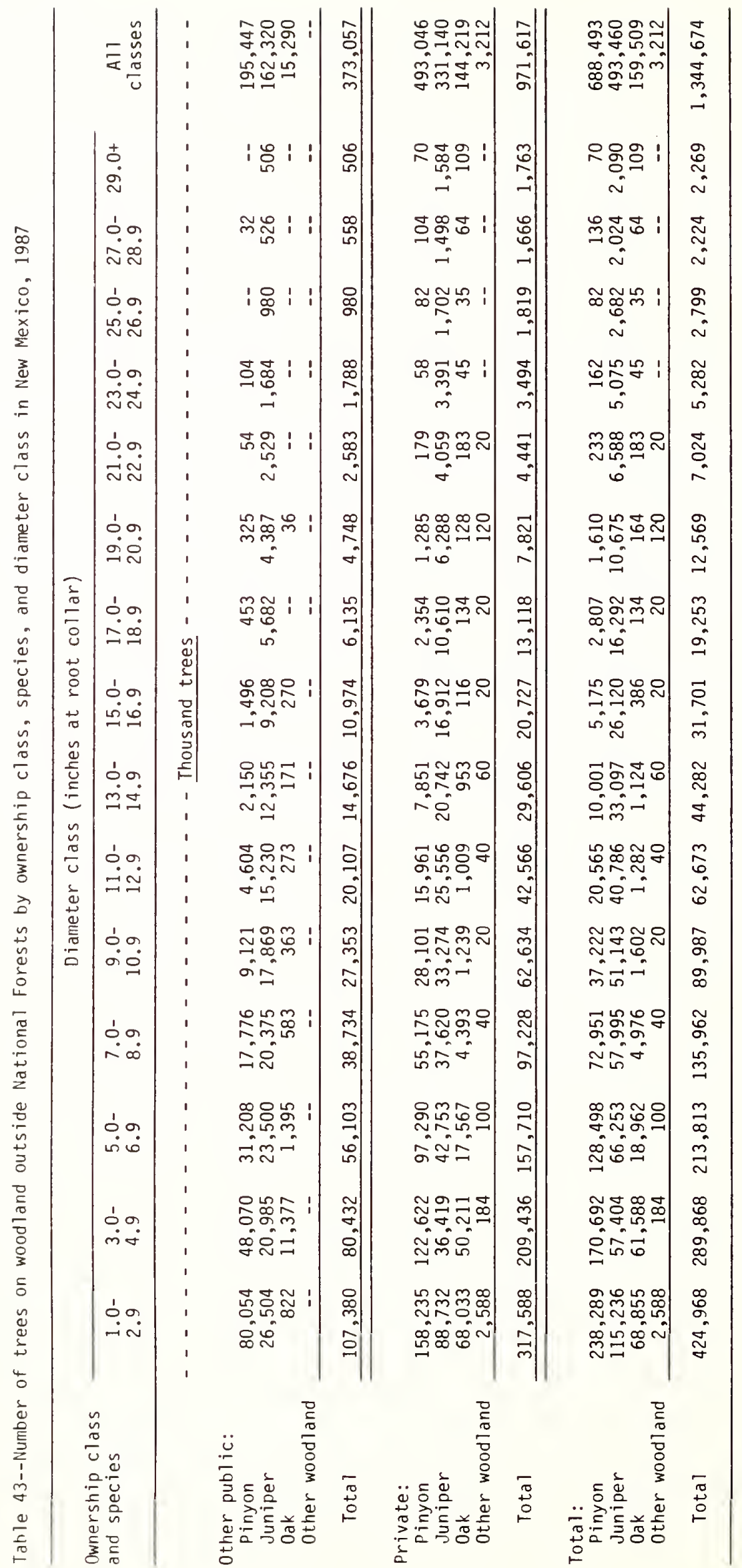


Table 44--Net volume on woodland outside National Forests by species and ownership class in New Mexico, 1987

\begin{tabular}{|c|c|c|c|}
\hline \multirow{2}{*}{ Species } & \multicolumn{2}{|c|}{ Ownership class } & \multirow[b]{2}{*}{ Total } \\
\hline & $\begin{array}{l}\text { Other } \\
\text { publ ic }\end{array}$ & Private & \\
\hline & ---- & usand cubic & ---- \\
\hline $\begin{array}{l}\text { Douglas-fir } \\
\text { Ponderosa pine } \\
\text { White fir } \\
\text { Cottonwood } \\
\text { Pinyon } \\
\text { Juniper } \\
\text { Oak } \\
\text { Other woodland }\end{array}$ & $\begin{array}{r}-- \\
10,158 \\
-- \\
-- \\
281,973 \\
459,135 \\
8,790 \\
-- \\
\end{array}$ & $\begin{array}{r}3,283 \\
52,512 \\
372 \\
1,357 \\
912,034 \\
869,451 \\
89,974 \\
4,774 \\
\end{array}$ & $\begin{array}{r}3,283 \\
62,670 \\
372 \\
1,357 \\
1,194,007 \\
1,328,586 \\
98,764 \\
4,774 \\
\end{array}$ \\
\hline All species & 760,056 & $1,933,757$ & $2,693,813$ \\
\hline
\end{tabular}




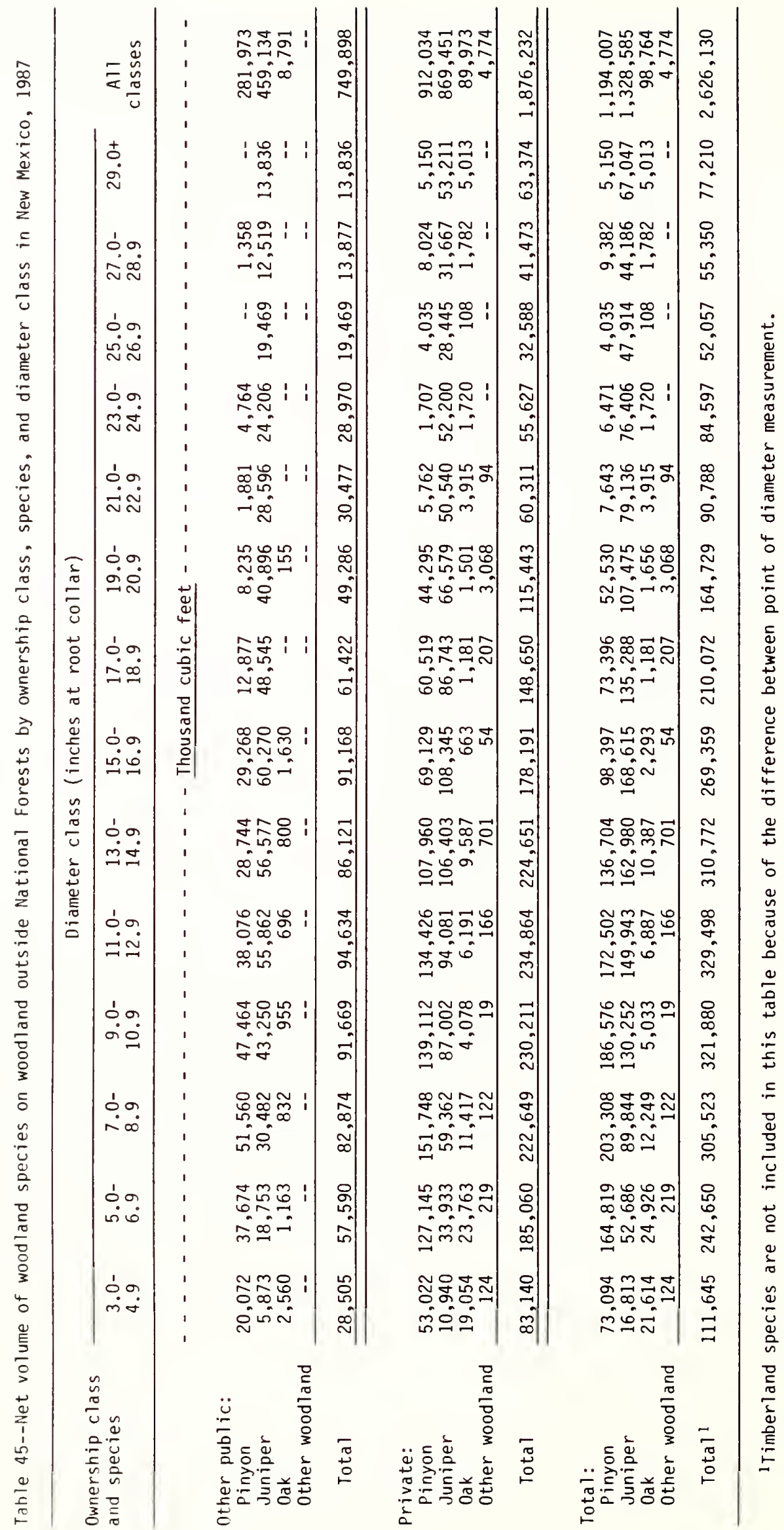


Table 46--Net volume on woodland outside National Forests by ownership class, forest type, and productivity class in New Mexico, 1987

\begin{tabular}{|c|c|c|c|c|}
\hline \multirow{2}{*}{$\begin{array}{l}\text { Ownership } \\
\text { class }\end{array}$} & \multirow{2}{*}{ Forest type } & \multicolumn{2}{|c|}{ Productivity class } & \multirow[b]{2}{*}{$\begin{array}{c}\text { All } \\
\text { classes }\end{array}$} \\
\hline & & High & Low & \\
\hline & & $----T h$ & nd cubic & et - - - . \\
\hline \multirow[t]{2}{*}{ Other public: } & $\begin{array}{l}\text { Pinyon-juniper } \\
\text { Juniper } \\
\text { Oak }\end{array}$ & $\begin{array}{r}563,136 \\
65,303 \\
4,678 \\
\end{array}$ & $\begin{array}{r}116,544 \\
7,336 \\
3,059 \\
\end{array}$ & $\begin{array}{r}679,680 \\
72,639 \\
7,737 \\
\end{array}$ \\
\hline & Total & 633,117 & 126,939 & 760,056 \\
\hline \multirow[t]{2}{*}{ Private: } & $\begin{array}{l}\text { Pinyon-juniper } \\
\text { Juniper } \\
\text { Oak }\end{array}$ & $\begin{array}{r}1,497,823 \\
93,707 \\
118,381 \\
\end{array}$ & $\begin{array}{r}196,797 \\
25,712 \\
1,337 \\
\end{array}$ & $\begin{array}{r}1,694,620 \\
119,419 \\
119,718 \\
\end{array}$ \\
\hline & Total & $1,709,911$ & 223,846 & $1,933,757$ \\
\hline \multirow[t]{2}{*}{ Total: } & $\begin{array}{l}\text { Pinyon-juniper } \\
\text { Juniper } \\
\text { Oak }\end{array}$ & $\begin{array}{r}2,060,959 \\
159,010 \\
123,059 \\
\end{array}$ & $\begin{array}{r}313,341 \\
33,048 \\
4,396 \\
\end{array}$ & $\begin{array}{r}2,374,300 \\
192,058 \\
127,455 \\
\end{array}$ \\
\hline & Total & $2,343,028$ & 350,785 & $2,693,813$ \\
\hline
\end{tabular}




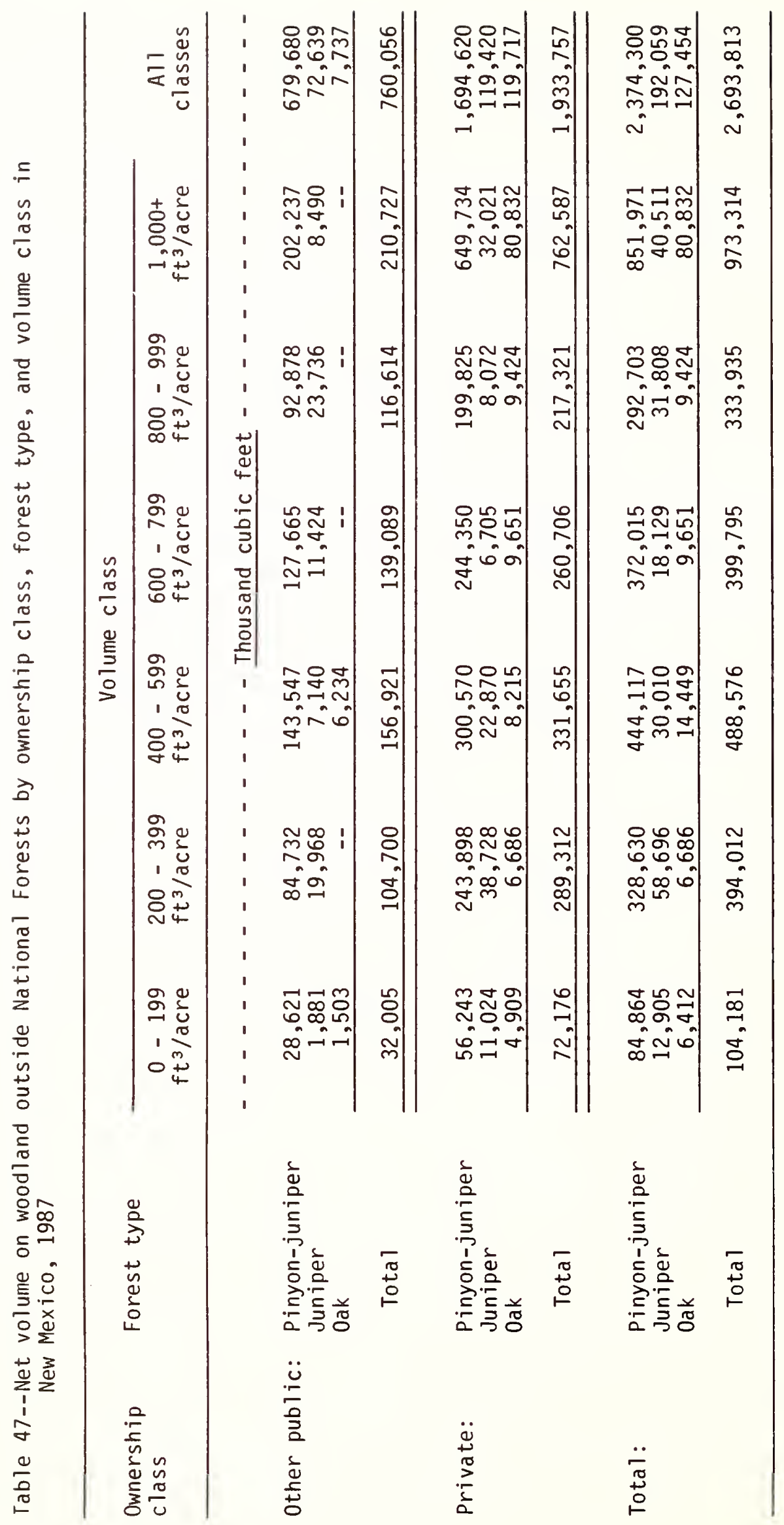




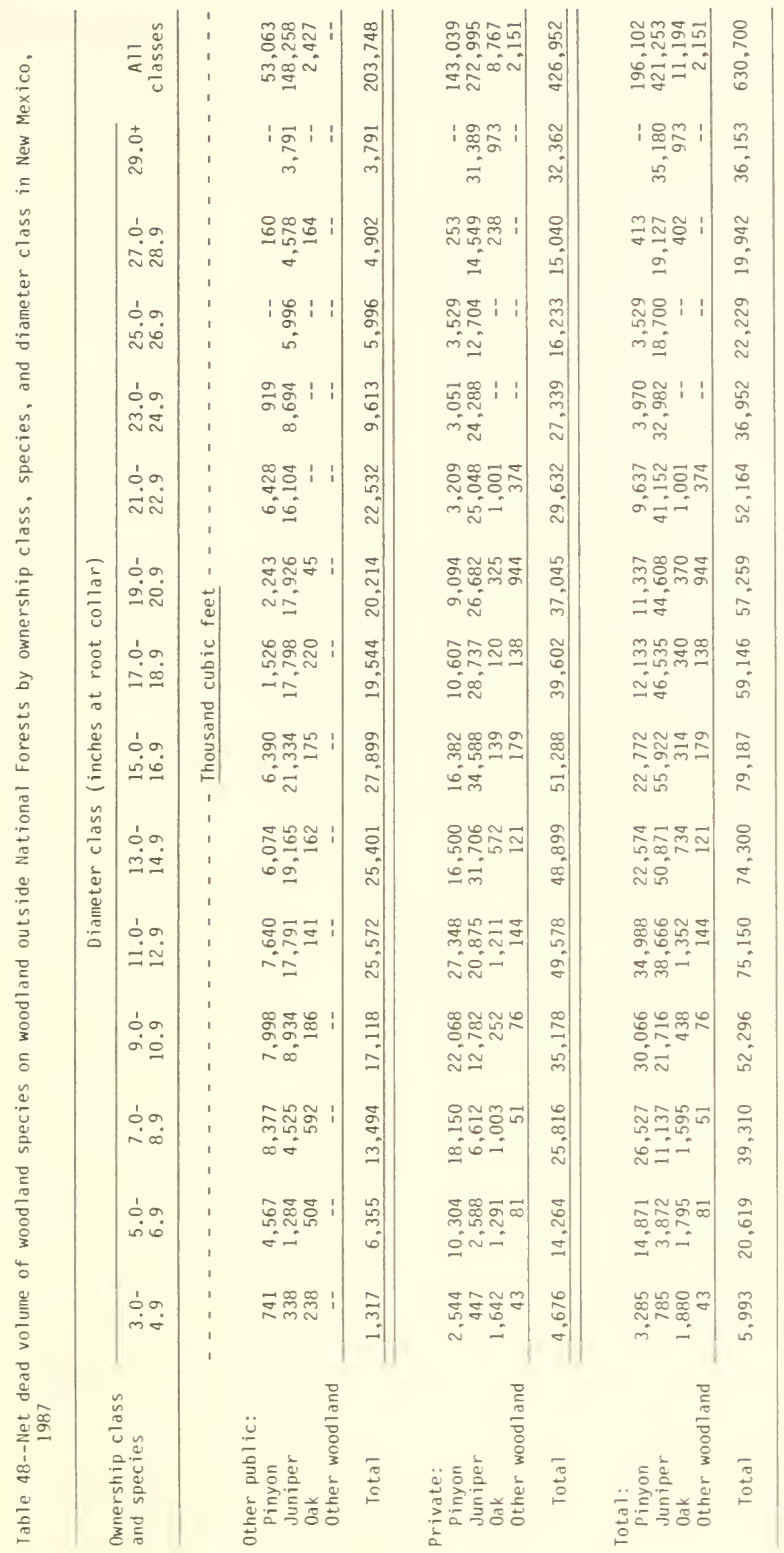


Table 49--Net dead volume of woodland species on woodland outside National Forests by ownership class, forest type, and productivity class in New Mexico, 1987

\begin{tabular}{|c|c|c|c|c|}
\hline \multirow{2}{*}{$\begin{array}{l}\text { Ownership } \\
\text { class }\end{array}$} & \multirow{2}{*}{ Forest type } & \multicolumn{2}{|c|}{ Productivity class } & \multirow[b]{2}{*}{$\begin{array}{c}\text { All } \\
\text { classes }\end{array}$} \\
\hline & & High & Low & \\
\hline & & $----\underline{T h}$ & nd cubic & $---=$ \\
\hline \multirow[t]{2}{*}{ Other public: } & $\begin{array}{l}\text { Pinyon-juniper } \\
\text { Juniper } \\
\text { Oak }\end{array}$ & $\begin{array}{r}145,040 \\
12,822 \\
126 \\
\end{array}$ & $\begin{array}{r}43,402 \\
1,501 \\
857 \\
\end{array}$ & $\begin{array}{r}188,442 \\
14,323 \\
983 \\
\end{array}$ \\
\hline & Total & 157,988 & 45,760 & 203,748 \\
\hline \multirow[t]{2}{*}{ Private: } & $\begin{array}{l}\text { Pinyon-juniper } \\
\text { Juniper } \\
\text { Oak }\end{array}$ & $\begin{array}{r}329,765 \\
13,421 \\
10,713 \\
\end{array}$ & $\begin{array}{r}67,214 \\
5,719 \\
120 \\
\end{array}$ & $\begin{array}{r}396,979 \\
19,140 \\
10,833 \\
\end{array}$ \\
\hline & Total & 353,899 & 73,053 & 426,952 \\
\hline \multirow[t]{2}{*}{ Tota 1: } & $\begin{array}{l}\text { Pinyon-juniper } \\
\text { Juniper } \\
\text { Oak }\end{array}$ & $\begin{array}{r}474,805 \\
26,243 \\
10,839 \\
\end{array}$ & $\begin{array}{r}110,616 \\
7,220 \\
977 \\
\end{array}$ & $\begin{array}{r}585,421 \\
33,463 \\
11,816 \\
\end{array}$ \\
\hline & Total & 511,887 & 118,813 & 630,700 \\
\hline
\end{tabular}




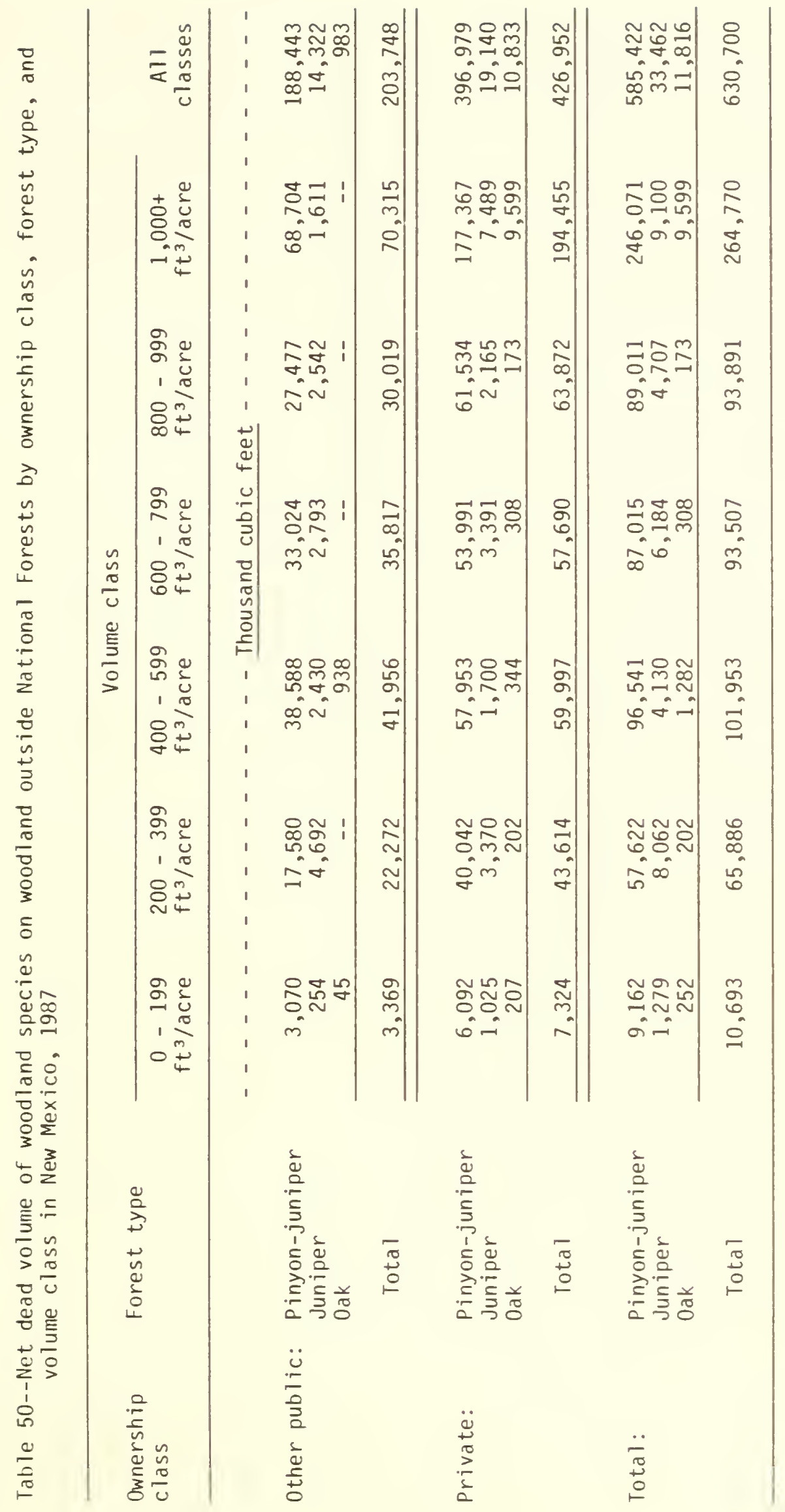


Table 51--Net annual growth on woodland outside National Forests by species and ownership class in New Mexico, 1986

\begin{tabular}{|c|c|c|c|}
\hline \multirow{2}{*}{ Species } & \multicolumn{2}{|c|}{ Ownership class } & \multirow[b]{2}{*}{ Total } \\
\hline & $\begin{array}{l}\text { Other } \\
\text { publ ic }\end{array}$ & Private & \\
\hline & $=--\cdots$ & sand cub & -- \\
\hline Douglas-fir & -- & 86 & 86 \\
\hline Ponderosa pine & 248 & 1,095 & 1,343 \\
\hline White fir & - & 47 & 47 \\
\hline Cottonwood & -- & 114 & 114 \\
\hline Pinyon & 4,113 & 12,881 & 16,994 \\
\hline Juniper & 3,010 & 6,054 & 9,064 \\
\hline Oak & 203 & 1,652 & 1,855 \\
\hline Other woodland & -- & 23 & 23 \\
\hline All species & 7,574 & 21,952 & 29,526 \\
\hline
\end{tabular}




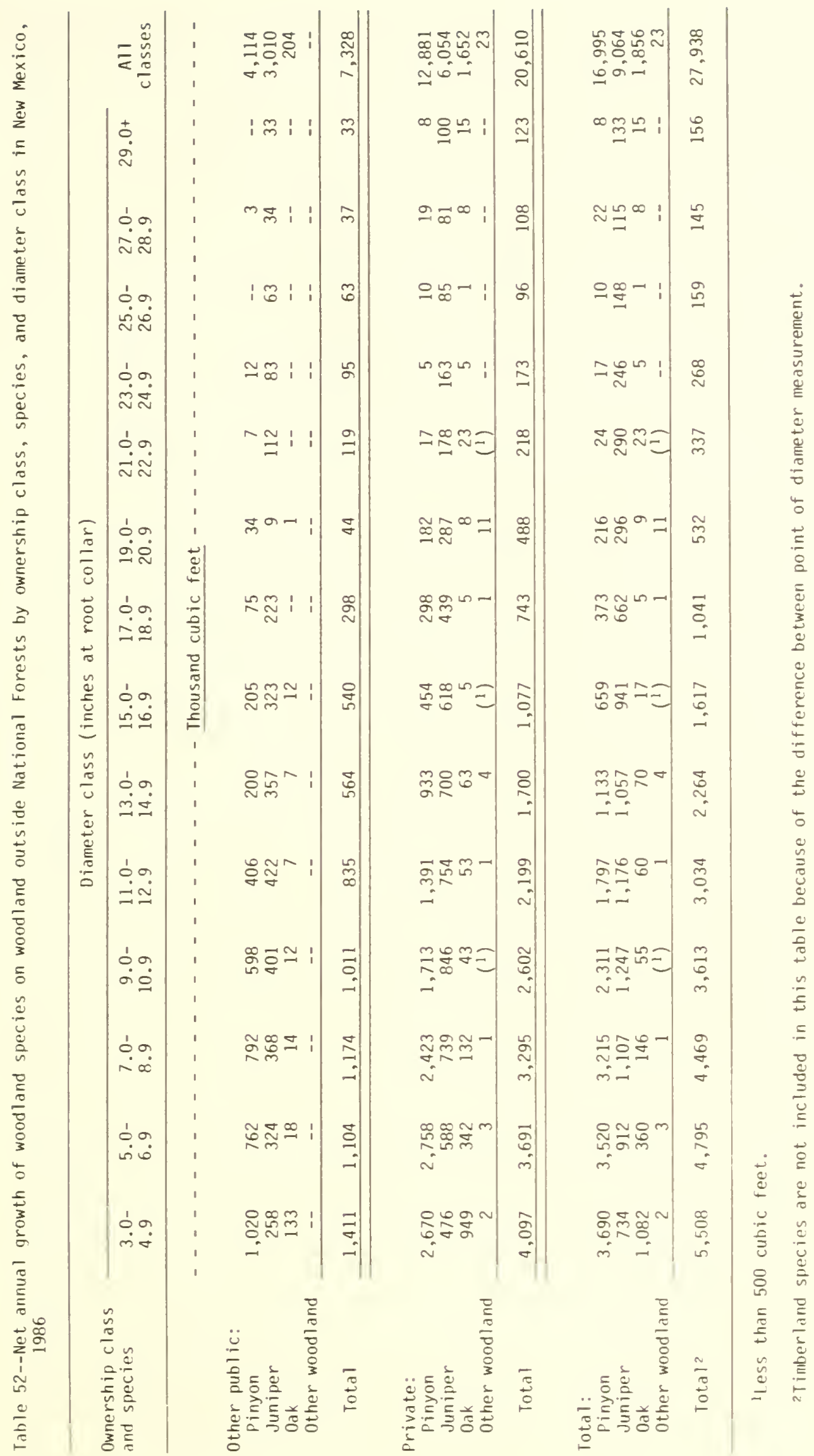


Table 53--Net annual growth on woodland outside National Forests by ownership class, forest type, and productivity class in New Mexico, 1986

\begin{tabular}{|c|c|c|c|c|}
\hline \multirow{2}{*}{$\begin{array}{l}\text { Ownership } \\
\text { class }\end{array}$} & \multirow{2}{*}{ Forest type } & \multicolumn{2}{|c|}{ Productivity class } & \multirow[b]{2}{*}{$\begin{array}{c}\text { All } \\
\text { classes }\end{array}$} \\
\hline & & High & Low & \\
\hline & & - - - & nd cubi & $t \cdots$ \\
\hline \multirow[t]{2}{*}{ Other public: } & $\begin{array}{l}\text { Pinyon-juniper } \\
\text { Juniper } \\
\text { Oak }\end{array}$ & $\begin{array}{r}5,902 \\
380 \\
113 \\
\end{array}$ & $\begin{array}{r}1,098 \\
57 \\
24 \\
\end{array}$ & $\begin{array}{r}7,000 \\
437 \\
137 \\
\end{array}$ \\
\hline & Total & 6,395 & 1,179 & 7,574 \\
\hline \multirow[t]{2}{*}{ Private: } & $\begin{array}{l}\text { Pinyon-juniper } \\
\text { Juniper } \\
\text { Oak }\end{array}$ & $\begin{array}{r}17,300 \\
617 \\
1,908 \\
\end{array}$ & $\begin{array}{r}1,926 \\
164 \\
\quad 37 \\
\end{array}$ & $\begin{array}{r}19,226 \\
781 \\
1,945 \\
\end{array}$ \\
\hline & Total & 19,825 & 2,127 & 21,952 \\
\hline \multirow[t]{2}{*}{ Total: } & $\begin{array}{l}\text { Pinyon-juniper } \\
\text { Juniper } \\
\text { Oak }\end{array}$ & $\begin{array}{r}23,202 \\
997 \\
2,021 \\
\end{array}$ & $\begin{array}{r}3,024 \\
221 \\
61 \\
\end{array}$ & $\begin{array}{r}26,226 \\
1,218 \\
2,082 \\
\end{array}$ \\
\hline & Total & 26,220 & 3,306 & 29,526 \\
\hline
\end{tabular}




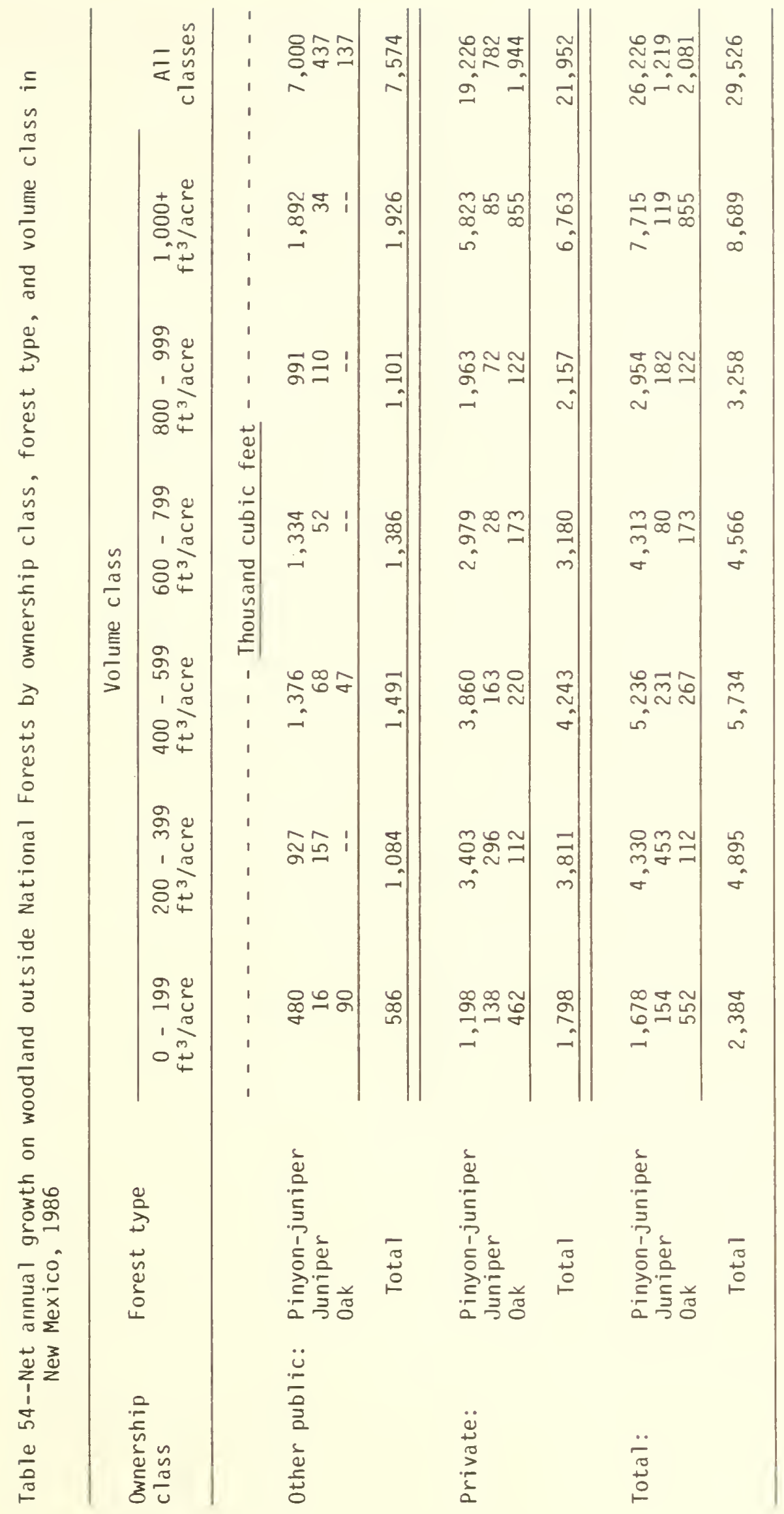


Table 55--Annual mortality on woodland outside National Forests by species and ownership class in New Mexico, 1986

\begin{tabular}{|c|c|c|c|}
\hline \multirow{2}{*}{ Species } & \multicolumn{2}{|c|}{ Ownership class } & \multirow[b]{2}{*}{ Total } \\
\hline & $\begin{array}{l}\text { Other } \\
\text { publ ic }\end{array}$ & Private & \\
\hline & ---- & sand cubi & -- \\
\hline Douglas-fir & -- & -- & -- \\
\hline Ponderosa pine & -- & -- & -- \\
\hline White fir & -- & -- & -- \\
\hline Cottonwood & -- & -- & -- \\
\hline Pinyon & 58 & 122 & 180 \\
\hline Juniper & 161 & 5 & 166 \\
\hline Oak & 7 & -- & 7 \\
\hline Other woodland & -- & -- & -- \\
\hline All species & 226 & 127 & 353 \\
\hline
\end{tabular}

Table 56--Number of pinyon Christmas trees on woodiand outside National Forests by ownership class, grade, and height class in New Mexico, 1987

\begin{tabular}{|c|c|c|c|c|c|}
\hline \multirow{2}{*}{$\begin{array}{l}\text { Ownership } \\
\text { class }\end{array}$} & \multirow{2}{*}{$\begin{array}{l}\text { Christmas-tree } \\
\text { grade }\end{array}$} & \multicolumn{3}{|c|}{ Height class } & \multirow{2}{*}{$\begin{array}{c}\text { Al1 } \\
\text { classes }\end{array}$} \\
\hline & & $0-5 \mathrm{ft}$ & $6-10 \mathrm{ft}$ & $11-12 \mathrm{ft}$ & \\
\hline & & ---- & - - Thous & trees - - & --- \\
\hline \multirow[t]{2}{*}{ Other public: } & $\begin{array}{l}\text { Premium } \\
\text { Standard } \\
\text { Utility }\end{array}$ & $\begin{array}{r}30 \\
1,824 \\
2,941 \\
\end{array}$ & $\begin{array}{r}362 \\
3,912 \\
9,536 \\
\end{array}$ & $\begin{array}{r}64 \\
825 \\
1,596 \\
\end{array}$ & $\begin{array}{r}456 \\
6,561 \\
14,073 \\
\end{array}$ \\
\hline & Total & 4,795 & 13,810 & 2,485 & 21,090 \\
\hline \multirow[t]{2}{*}{ Private: } & $\begin{array}{l}\text { Premium } \\
\text { Standard } \\
\text { Utility }\end{array}$ & $\begin{array}{r}952 \\
3,378 \\
16,120 \\
\end{array}$ & $\begin{array}{r}1,620 \\
8,325 \\
25,849 \\
\end{array}$ & $\begin{array}{r}138 \\
1,428 \\
4,554 \\
\end{array}$ & $\begin{array}{r}2,710 \\
13,131 \\
46,523 \\
\end{array}$ \\
\hline & Total & 20,450 & 35,794 & 6,120 & 62,364 \\
\hline \multirow[t]{2}{*}{ Total: } & $\begin{array}{l}\text { Premium } \\
\text { Standard } \\
\text { Utility }\end{array}$ & $\begin{array}{r}982 \\
5,202 \\
19,061 \\
\end{array}$ & $\begin{array}{r}1,982 \\
12,237 \\
35,385 \\
\end{array}$ & $\begin{array}{r}202 \\
2,253 \\
6,150 \\
\end{array}$ & $\begin{array}{r}3,166 \\
19,692 \\
60,596 \\
\end{array}$ \\
\hline & Total & 25,245 & 49,604 & 8,605 & 83,454 \\
\hline
\end{tabular}


Table 57--Number of fenceposts on woodland outside National Forests by ownership class, species, and type of post in New Mexico, 1987

\begin{tabular}{|c|c|c|c|c|}
\hline \multirow{2}{*}{$\begin{array}{l}\text { Ownership } \\
\text { class }\end{array}$} & \multirow{2}{*}{ Species } & \multicolumn{2}{|c|}{ Type of post } & \multirow[b]{2}{*}{ Total } \\
\hline & & Line & Corner & \\
\hline & & $---I$ & nd fence & $\underline{s}--$ \\
\hline \multirow[t]{2}{*}{ Other public: } & $\begin{array}{l}\text { Juniper } \\
\text { Oak }\end{array}$ & $\begin{array}{r}22,997 \\
540 \\
\end{array}$ & $\begin{array}{r}11,419 \\
102 \\
\end{array}$ & $\begin{array}{r}34,416 \\
642 \\
\end{array}$ \\
\hline & Total & 23,537 & 11,521 & 35,058 \\
\hline \multirow[t]{2}{*}{ Private: } & $\begin{array}{l}\text { Juniper } \\
\text { Oak }\end{array}$ & $\begin{array}{l}39,630 \\
12,236 \\
\end{array}$ & $\begin{array}{r}22,400 \\
3,132 \\
\end{array}$ & $\begin{array}{l}62,030 \\
15,368 \\
\end{array}$ \\
\hline & Total & 51,866 & 25,532 & 77,398 \\
\hline \multirow[t]{2}{*}{ Total: } & $\begin{array}{l}\text { Juniper } \\
\text { Oak }\end{array}$ & $\begin{array}{l}62,627 \\
12,776 \\
\end{array}$ & $\begin{array}{r}33,819 \\
3,234 \\
\end{array}$ & $\begin{array}{l}96,446 \\
16,010 \\
\end{array}$ \\
\hline & Total & 75,403 & 37,053 & 112,456 \\
\hline
\end{tabular}


Table 58--Area of timberland outside National Forests by county in New Mexico, 1987

\begin{tabular}{|c|c|}
\hline County & Area \\
\hline & - Acres - - \\
\hline $\begin{array}{l}\text { Bernalillo } \\
\text { Catron }\end{array}$ & 16,300 \\
\hline $\begin{array}{l}\text { Catron } \\
\text { Chaves }\end{array}$ & $\begin{array}{r}40,302 \\
515\end{array}$ \\
\hline Cibola & 101,619 \\
\hline Colfax & 456,111 \\
\hline Curry & -- \\
\hline De Baca & 691 \\
\hline Dona Ana & 1,910 \\
\hline Eddy & -- \\
\hline Grant & 13,170 \\
\hline Guadal upe & 6,117 \\
\hline Harding & 6,144 \\
\hline Hidalgo & 4,268 \\
\hline Lea & -- \\
\hline Lincoln & 20,435 \\
\hline Los Alamos & 1,973 \\
\hline Luna & 1,733 \\
\hline Mckinley & 104,904 \\
\hline Mora & 183,042 \\
\hline Otero & 270,263 \\
\hline Quay & 6,098 \\
\hline Rio Arriba & 319,936 \\
\hline Roosevelt & - \\
\hline Sandoval & 100,075 \\
\hline San Juan & 126,250 \\
\hline San Miguel & 95,097 \\
\hline Santa Fe & 37,665 \\
\hline Sierra & 2,282 \\
\hline Socorro & 9,870 \\
\hline Taos & 123,844 \\
\hline Torrance & 23,428 \\
\hline Union & 13,026 \\
\hline Valencia & 12,224 \\
\hline Total & $2,099,292$ \\
\hline
\end{tabular}


Table 59--Net volume of growing stock and sawtimber on timberland outside National Forests by county in New Mexico, 1987

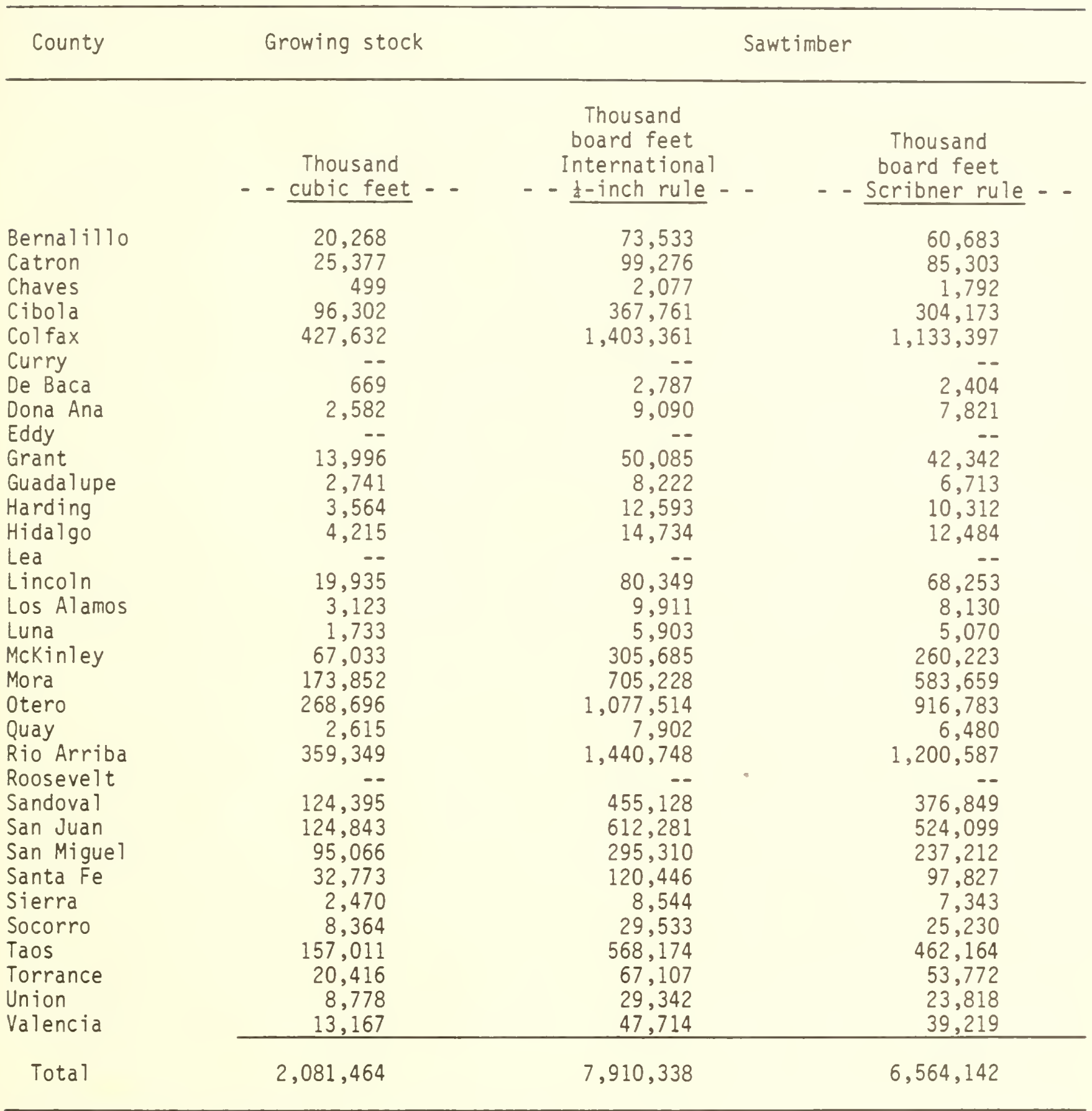


Table 60--Net annual growth of growing stock and sawtimber on timberland outside National Forests by county in New Mexico, 1986

\begin{tabular}{|c|c|c|c|}
\hline \multirow{2}{*}{ County } & Growing stock & \multicolumn{2}{|c|}{ Sawtimber } \\
\hline & $\begin{array}{c}\text { Thousand } \\
\text { - - cubic feet - - }\end{array}$ & $\begin{array}{c}\text { Thousand } \\
\text { board feet } \\
\text { International } \\
\text { - - } \frac{1}{4-i n c h ~ r u l e ~-~}\end{array}$ & $\begin{array}{c}\text { Thousand } \\
\text { board feet } \\
\text { - - Scribner rule - - }\end{array}$ \\
\hline $\begin{array}{l}\text { Bernalillo } \\
\text { Catron } \\
\text { Chaves } \\
\text { Cibola } \\
\text { Colfax }\end{array}$ & $\begin{array}{r}523 \\
781 \\
10 \\
2,589 \\
7,537\end{array}$ & $\begin{array}{r}2,333 \\
3,209 \\
56 \\
11,031 \\
32,723\end{array}$ & $\begin{array}{r}1,989 \\
2,746 \\
45 \\
9,269 \\
26,641\end{array}$ \\
\hline Curry & $=$ & $=$ & 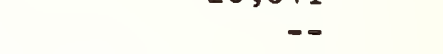 \\
\hline De Baca & 13 & 76 & 61 \\
\hline Dona Ana & 106 & 285 & 250 \\
\hline Eddy & - & - & - \\
\hline Grant & 328 & 1,560 & 1,255 \\
\hline Guada lupe & 118 & 706 & 490 \\
\hline Harding & 118 & 961 & 672 \\
\hline Hidalgo & 125 & 452 & 368 \\
\hline Lea & $=$ & -- & - \\
\hline Lincoln & 458 & 2,467 & 2,063 \\
\hline Los Alamos & 79 & 380 & 317 \\
\hline Luna & 78 & 183 & 160 \\
\hline Mckinley & 1,568 & 5,589 & 4,815 \\
\hline Mora & 5,980 & 25,250 & 20,941 \\
\hline otero & 9,243 & 50,653 & 41,878 \\
\hline Quay & 114 & 676 & 469 \\
\hline Rio Arriba & 8,907 & 38,288 & 32,373 \\
\hline Roosevelt & $=--$ & -- & -- \\
\hline Sandoval & 3,170 & 15,560 & 13,336 \\
\hline San Juan & 2,705 & 12,493 & 10,604 \\
\hline San Miguel & 2,975 & 14,038 & 10,691 \\
\hline Santa $\mathrm{Fe}$ & 887 & 4,084 & 3,477 \\
\hline Sierra & 107 & 264 & 232 \\
\hline Socorro & 308 & 836 & 750 \\
\hline Taos & 4,476 & 16,092 & 13,519 \\
\hline Torrance & 663 & 4,978 & 3,535 \\
\hline Union & 243 & 1,785 & 1,264 \\
\hline Valencia & 355 & 1,303 & 1,099 \\
\hline Total & 54,564 & 248,311 & 205,309 \\
\hline
\end{tabular}


Table 61--Annual mortality of growing stock and sawtimber on timberland outside National Forests by county in New Mexico, 1986

\begin{tabular}{|c|c|c|c|}
\hline County & Growing stock & & imber \\
\hline & $\begin{array}{l}\text { Thousand } \\
\text { - - cubic feet - - }\end{array}$ & $\begin{array}{c}\text { Thousand } \\
\text { board feet } \\
\text { International } \\
\text { - }- \text { +-inch rule - - }\end{array}$ & $\begin{array}{c}\text { Thousand } \\
\text { board feet } \\
\text { - - Scribner rule - - }\end{array}$ \\
\hline Bernalillo & 28 & 110 & 90 \\
\hline Catron & -- & - & -- \\
\hline Chaves & 3 & 15 & 14 \\
\hline Cibola & 230 & 895 & 718 \\
\hline Colfax & 4,278 & 11,724 & 8,889 \\
\hline Curry & -- & -- & -- \\
\hline De Baca & 4 & 21 & 18 \\
\hline Dona Ana & -- & -- & -- \\
\hline Eddy & -- & -- & -- \\
\hline Grant & -- & -- & -- \\
\hline Guadalupe & -- & -- & -- \\
\hline Harding & 12 & 36 & 28 \\
\hline Hidalgo & - & -- & -- \\
\hline Lea & -- & -- & -- \\
\hline Lincoln & 85 & 401 & 356 \\
\hline Los Alamos & 3 & 12 & 10 \\
\hline Luna & -- & -- & -- \\
\hline McKinley & 51 & 200 & 164 \\
\hline Mora & 11 & 48 & 36 \\
\hline Otero & 313 & 1,241 & 1,105 \\
\hline Quay & -- & -- & -- \\
\hline Rio Arriba & 566 & 2,208 & 1,814 \\
\hline Roosevelt & -- & -. & -- \\
\hline Sandoval & 195 & 760 & 625 \\
\hline San Juan & 12 & 45 & 37 \\
\hline San Miguel & 38 & 166 & 125 \\
\hline Santa Fe & 46 & 179 & 147 \\
\hline Sierra & -- & -- & -- \\
\hline Socorro & -- & -- & -- \\
\hline Taos & 274 & 1,070 & 879 \\
\hline Torrance & - & -- & -- \\
\hline Union & 58 & 167 & 126 \\
\hline Valencia & 14 & 53 & 43 \\
\hline Tota 1 & 6,221 & 19,351 & 15,224 \\
\hline
\end{tabular}


Table 62--Area, net volume, net annual growth, and net annual mortality of woodland species on woodland outside National Forests by county in New Mexico

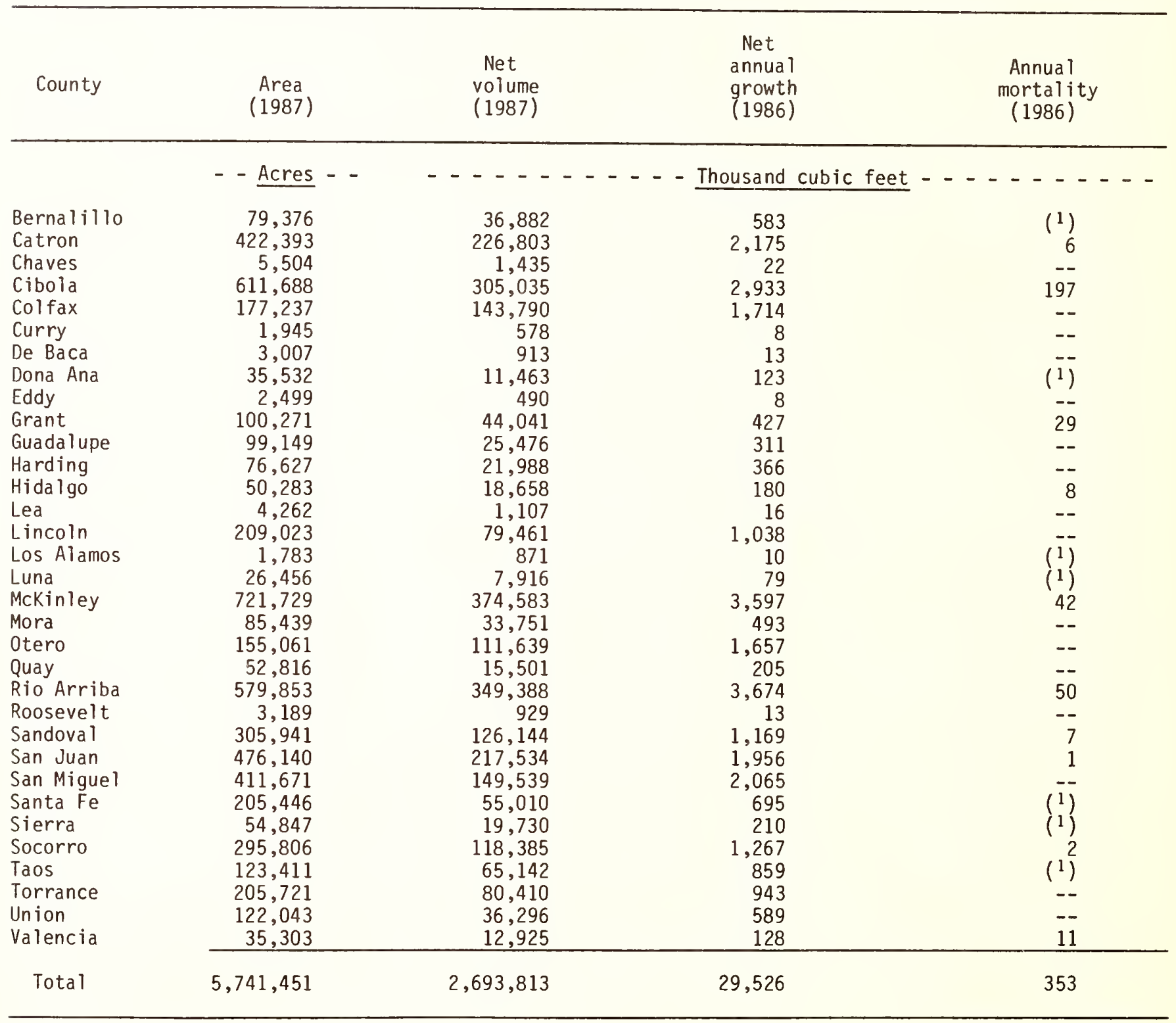

${ }^{1}$ Less than 500 cubic feet. 
Van Hooser, Dwane D. 1990. Timberland and woodland resources outside National

Forests in New Mexico, 1987. Resour. Bull. INT-68. Ogden, UT: U.S. Department of Agriculture, Forest Service, Intermountain Research Station. 72 p.

Presents land area, timberland and woodland area, associated volume, and components of change for the forest lands outside the National Forests in New Mexico.

KEYWORDS: forest survey, inventory, volume, pinyon-juniper 


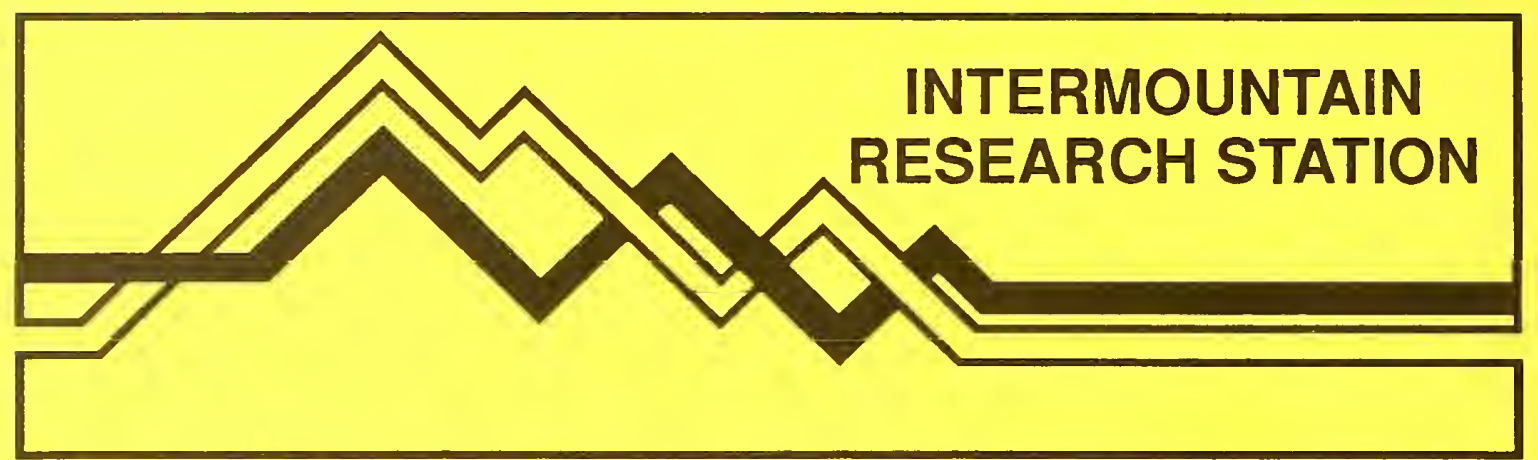

The Intermountain Research Station provides scientific knowledge and technology to improve management, protection, and use of the forests and rangelands of the Intermountain West. Research is designed to meet the needs of National Forest managers, Federal and State agencies, industry, academic institutions, public and private organizations, and individuals. Results of research are made available through publications, symposia, workshops, training sessions, and personal contacts.

The Intermountain Research Station territory includes Montana, Idaho, Utah, Nevada, and western Wyoming. Eighty-five percent of the lands in the Station area, about 231 million acres, are classified as forest or rangeland. They include grasslands, deserts, shrublands, alpine areas, and forests. They provide fiber for forest industries, minerals and fossil fuels for energy and industrial development, water for domestic and industrial consumption, forage for livestock and wildlife, and recreation opportunities for millions of visitors.

Several Station units conduct research in additional western States, or have missions that are national or international in scope.

Station laboratories are located in:

Boise, Idaho

Bozeman, Montana (in cooperation with Montana State University)

Logan, Utah (in cooperation with Utah State University)

Missoula, Montana (in cooperation with the University of Montana)

Moscow, Idaho (in cooperation with the University of Idaho)

Ogden, Utah

Provo, Utah (in cooperation with Brigham Young University)

Reno, Nevada (in cooperation with the University of Nevada)

USDA policy prohibits discrimination because of race, color, national origin, sex, age, religion, or handicapping condition. Any person who believes he or she has been discriminated against in any USDA-related activity should immediately contact the Secretary of Agriculture, Washington, DC 20250. 